\title{
Imidazoline Receptor System: The Past, the Present, and the Future
}

\author{
Pascal Bousquet, Alan Hudson, Jesús A. García-Sevilla, and Jun-Xu Li
}

Faculty of Medicine, University of Strasbourg, Strasbourg, France (P.B.); Department of Pharmacology, University of Alberta, Edmonton, Alberta, Canada (A.H.); Laboratory of Neuropharmacology, University Research Institute on Health Sciences, University of the Balearic Islands, Palma de Malllorca, Spain (J.A.G.-S.); and Department of Pharmacology and Toxicology, University at Buffalo, Buffalo, New York (J.-X.L.)

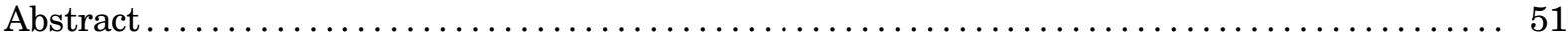

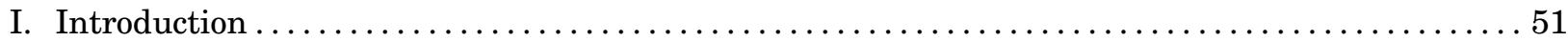

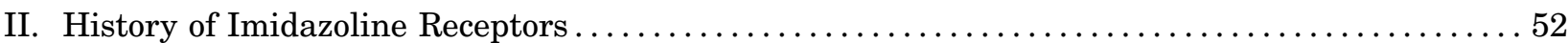

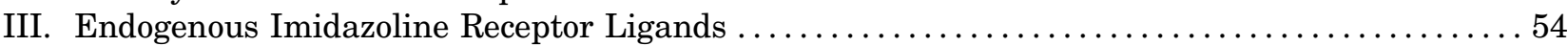

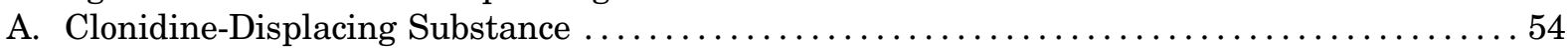

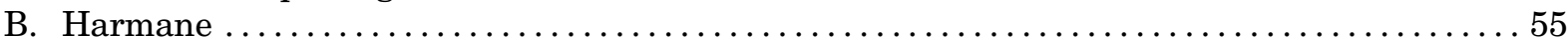

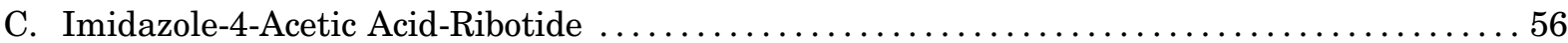

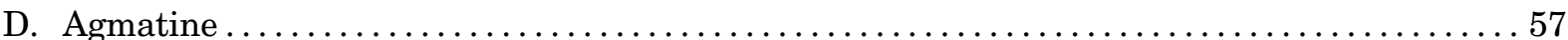

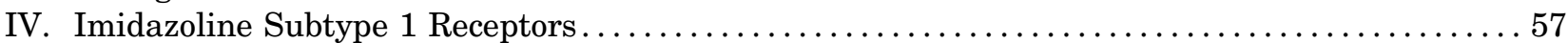

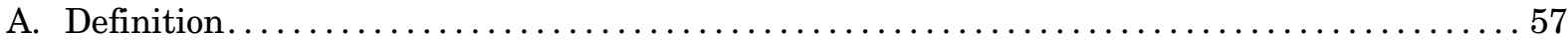

B. Specific Binding Properties, Selective Ligands, and Tissue and Subcellular

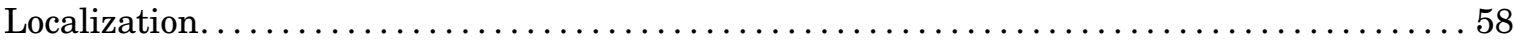

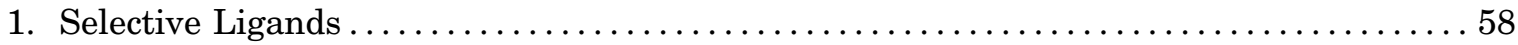

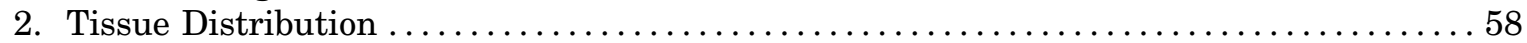

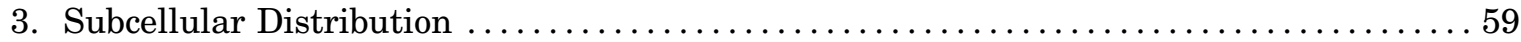

4. Second-Generation Imidazoline Subtype 1 Receptor Ligands . . . . . . . . . . . . . 59

5. Selective Imidazoline Subtype 1 Receptor Ligands with High Affinity as

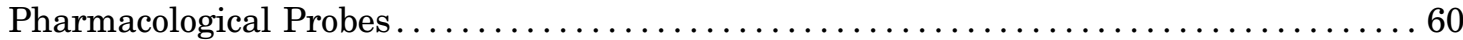

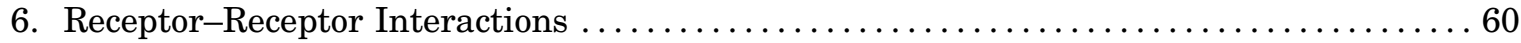

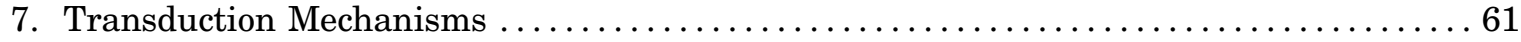

8. Attempts to Clone Imidazoline Subtype 1 Receptors . . . . . . . . . . . . . . . . 62

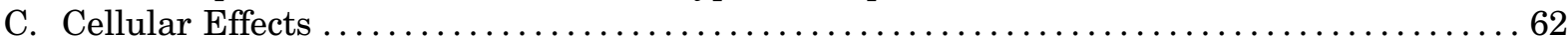

1. Imidazoline Subtype 1 Receptors and Apoptosis, Cell Viability, Growth, and

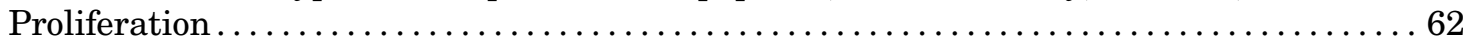

2. Imidazoline Subtype 1 Receptors and Insulin and Adiponectin .............62

3. Imidazoline Subtype 1 Receptors and Neurons $\ldots \ldots \ldots \ldots \ldots \ldots \ldots \ldots \ldots \ldots \ldots \ldots \ldots \ldots \ldots$

D. Imidazoline Subtype 1 Receptors and In Vivo Effects $\ldots \ldots \ldots \ldots \ldots \ldots$

1. Effects on Blood Pressure and Heart Rate ..........................63

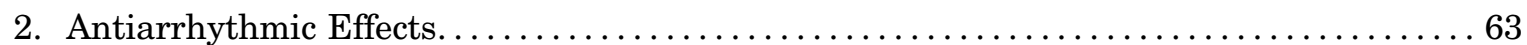

3. Effects in Congestive Heart Failure $\ldots \ldots \ldots \ldots \ldots \ldots \ldots \ldots \ldots \ldots \ldots \ldots \ldots \ldots \ldots \ldots \ldots \ldots \ldots$

4. Effects on Glucose and Lipid Metabolism and Interest in Metabolic Syndrome .......63

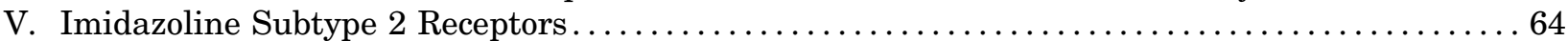

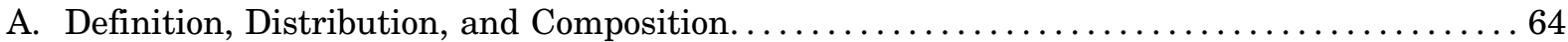

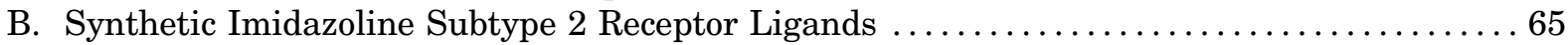

C. Neuropharmacology of Imidazoline Subtype 2 Receptor Ligands................66

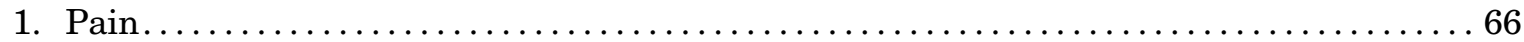

Address correspondence to: Jun-Xu Li, Department of Pharmacology and Toxicology, Jacobs School of Medicine and Biomedical Sciences, University at Buffalo, 955 Main St., Buffalo, NY 14203. E-mail: junxuli@buffalo.edu

P.B. and A.H. contributed equally to this work.

J.A.G.-S. and J.-X.L. contributed equally to this work.

https://doi.org/10.1124/pr.118.016311. 
2. Discriminative Stimulus Effects.................................. 68

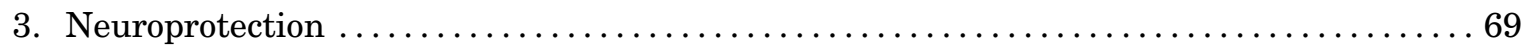

4. Body Temperature ........................................... 70

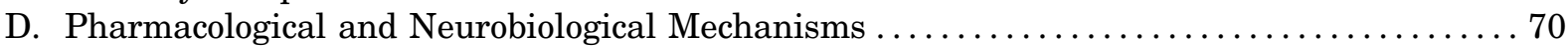

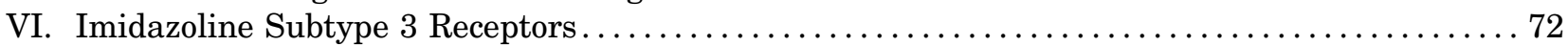

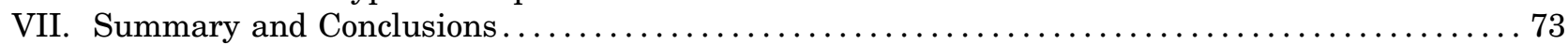

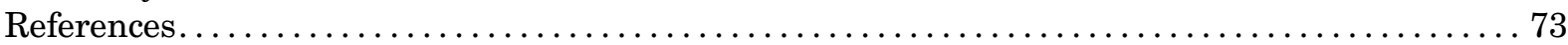

Abstract_-Imidazoline receptors historically referred to a family of nonadrenergic binding sites that recognize compounds with an imidazoline moiety, although this has proven to be an oversimplification. For example, none of the proposed endogenous ligands for imidazoline receptors contain an imidazoline moiety but they are diverse in their chemical structure. Three receptor subtypes $\left(I_{1}, I_{2}\right.$, and $\left.I_{3}\right)$ have been proposed and the understanding of each has seen differing progress over the decades. $I_{1}$ receptors partially mediate the central hypotensive effects of clonidine-like drugs. Moxonidine and rilmenidine have better therapeutic profiles (fewer side effects) than clonidine as antihypertensive drugs, thought to be due to their higher $I_{1} / \alpha_{2}$-adrenoceptor selectivity. Newer $I_{1}$ receptor agonists such as LNP599 [3-chloro-2methyl-phenyl)-(4-methyl-4,5-dihydro-3 $\mathrm{H}$-pyrrol-2-yl)amine hydrochloride] have little to no activity on $\alpha_{2}$-adrenoceptors and demonstrate promising therapeutic potential for hypertension and metabolic syndrome. $\mathbf{I}_{2}$ receptors associate with several distinct proteins, but the identities of these proteins remain elusive. $I_{2}$ receptor agonists have demonstrated various centrally mediated effects including antinociception and neuroprotection. A new $\mathrm{I}_{2}$ receptor agonist, $\mathrm{CR} 4056$ [2-phenyl-6-( $1 \mathrm{H}$-imidazol1yl) quinazoline], demonstrated clear analgesic activity in a recently completed phase II clinical trial and holds great promise as a novel $I_{2}$ receptor-based firstin-class nonopioid analgesic. The understanding of $I_{3}$ receptors is relatively limited. Existing data suggest that $I_{3}$ receptors may represent a binding site at the Kir6.2-subtype ATP-sensitive potassium channels in pancreatic $\beta$-cells and may be involved in insulin secretion. Despite the elusive nature of their molecular identities, recent progress on drug discovery targeting imidazoline receptors $\left(I_{1}\right.$ and $I_{2}$ ) demonstrates the exciting potential of these compounds to elicit neuroprotection and to treat various disorders such as hypertension, metabolic syndrome, and chronic pain.

\section{Introduction}

Although the imidazoline receptor concept was proposed decades ago and the field has been consistently evolving, many pharmacologists have not yet heard about this receptor. This is not surprising because, to some extent, this concept has not received unanimous acceptance in the biomedical community. For example, in the 12th edition of Goodman \& Gilman's The Pharmacological Basis of Therapeutics (Brunton et al., 2011), there is only one sentence mentioning imidazoline receptors. In the fifth edition of the Guide to Receptors and Channels (Alexander et al., 2011), imidazoline receptors are only briefly described under the entry on $\alpha_{2}$-adrenoceptors. However, there has recently been renewed interest in increasing understanding and pharmacological study of this system due to exciting new developments regarding the therapeutic potential of imidazoline receptor ligands. This review provides a comprehensive update on the historical and current status of imidazoline receptor research and offers our perspective on future directions.

\footnotetext{
ABBREVIATIONS: 2-BFI, 2-(2-benzofuranyl)-2-imidazoline; AMPA, $\alpha$-amino-3-hydroxy-5-methyl-4-isoxazolepropionic acid; AMPK, 5' adenosine monophosphate-activated protein kinase; BU216, 3-[4,5-dihydroimidaz-2-yl]-quinoline hydrochloride; BU224, 2-[4,5-dihydroimidaz-2-yl]-quinoline hydrochloride; BU226, 2-[4,5-dihydroimidaz-2-yl]-isoquinoline hydrochloride; CCI, chronic constriction injury; CDS, clonidine-displacing substance; CFA, complete Freund's adjuvant; CNS, central nervous system; CR4056, 2-phenyl-6-(1H-imidazol-1yl) quinazoline; DSP-4, $N$-(2-chloroethyl)- $N$-ethyl-2-bromobenzylamine; ERK, extracellular signal-regulated kinase; HPLC, high-performance liquid chromatography; IAA-RP, imidazole-4-acetic acid-ribotide; IRAS, imidazoline receptor antisera-selected; $\mathrm{K}_{\mathrm{ATP}}$, ATP-sensitive potassium; KU14-R, 2-(2-ethyl-2,3-dihydro-2-benzofuranyl)-1H-imidazole; LNP509, cis-/trans-dicyclopropylmethyl-(4,5-dimethyl-4,5-dihydro-3H-pyrrol2-yl)-amine; LNP599, 3-chloro-2-methyl-phenyl)-(4-methyl-4,5-dihydro-3H-pyrrol-2-yl)-amine hydrochloride; LNP630, (2,6-dichloro-phenyl)(4-methyl-4,5-dihydro-1H-imidazol-2-yl)-amine; LNP906, 2-(5-azido-2-chloro-4-iodo-phenylamino)-5-methyl-pyrroline; LNP911, (2-(2-chloro-4iodo-phenylamino)-5-methyl-pyrroline; LSL60101, 2-[2-benzofuranyl]-2-imidazole hydrochloride; LSL60125, 2-[6-methoxybenzofuran-2-yl] imidazole hydrochloride; LSL61122 (tracizoline), 2-styryl-4,5-dihydro-l $H$-imidazole; MAO, monoamine oxidase; MAPK, mitogen-activated protein kinase; MDL100907, $(R)$-(+)- $\alpha$-(2,3-dimethoxyphenyl)-1-[2-(4-fluorophenyl)ethyl]-4-piperinemethanol; NAQ, 17-cyclopropylmethyl3,14 $\beta$-dihydroxy-4,5 $\alpha$-epoxy-6 $\alpha$-[(3'-isoquinolyl) acetamido] morphine; NMDA, $N$-methyl-D-aspartic acid; NRL, nucleus reticularis lateralis; PAC, para-aminoclonidine; PC-PLC, phosphatidylcholine-specific phospholipase C; PET, positron emission tomography; phenyzoline, 4,5dihidro-2-(2-phenylethyl)-1H-imidazole; RO41-1049, $\mathrm{N}$-(2-aminoethyl)-5-(3-fluorophenyl)-4-thiazolecarboxamide hydrochloride; RS45041, 4chloro-2-(imidazolin-2-yl)isoindoline hydrochloride; RX82-1002, 2-(2,3-dihydro-2-methoxy-1,4-benzodioxin-2-yl)-4,5-dihydro-1 $H$-imidazole hydrochloride; S22687, 5-[2-methyl phenoxy methyl]-1,3-oxazolin-2-yl) amine; S43126, 2-[40-methoxyphenyl]-4,5-dihydro- $1 H$-imidazole; SHROB, spontaneously hypertensive obese; ST91, 2-(2,6-diethylphenylamino)-2-imidazoline hydrochloride; SUR1, sulfonylurea receptor 1; TNF- $\alpha$, tumor necrosis factor $\alpha$; W-7, $N$-(6-aminohexyl)-5-chloro-1-naphthalenesulfonamide hydrochloride; WAY100135, (S)- $N$-tert-butyl-3-(4-(2-methoxyphenyl)-piperazin-1yl)-2-phenylpropanamide; WB4101, 2-(2,6-dimethoxyphenoxyethyl)aminomethyl-1,4-benzodioxane hydrochloride; WIN52212-2, (R)-(+)-[2,3-dihydro-5methyl-3-[(4-morpholino)methyl]pyrrolo-[1,2,3-de]-1,4-benzoxazin-6-yl](1-naphthyl)methanone.
} 


\section{History of Imidazoline Receptors}

The early history of imidazolines and their receptors is very closely linked to that of clonidine. Clonidine is also a product of the $\alpha_{2}$-adrenergic receptor history. The stories of imidazolines and clonidine have subsequently remained intertwined but each has developed separately over time.

Clonidine was designed and synthesized by Stähle (2000) in the 1960s. Clonidine contains an imidazoline ring - that is, a five-atom ring, two of which are nitrogen atoms. Clonidine was first code-named ST155 (Shaw et al., 1971). More specifically, clonidine is an aminoimidazoline because there is a nitrogen atom between the imidazoline ring and the phenyl ring (see Fig. 1) (Stähle, 2000). Thus, the word "imidazoline" comes directly from the chemical name of the series of which clonidine is a member. In very exceptional cases, some authors also refer to the iminoimidazolidine structure due to the delocalization of the double bond around the intercyclic nitrogen atom (Leclerc et al., 1980; Stähle, 2000). The compound obviously contracts the vascular vessels and would have been of interest in the treatment of rhinorrhea (Corboz et al., 2013). However, it was never developed or used as such, since clonidine was shown to reduce blood pressure and heart rate at the time of the first trials in humans (Nayler et al., 1966; McRaven et al., 1971; Stähle, 2000).

A vasoconstrictive agent that lowers blood pressure was obviously not expected. Yet a drug that lowers blood pressure and simultaneously slows the heart rate was also very intriguing. The antihypertensive drugs known at that time reduced blood pressure because of their vasodilatory properties; peripheral vasodilators are known to usually accelerate cardiac rhythm through the baroreflex (Cohn et al., 2011). Therefore, clonidine constituted from the beginning some kind of double paradox. Credit goes to Kobinger who showed that the hypotensive effect of clonidine originates in the central nervous system (CNS) and that the same applies to its bradycardic effect (Kobinger, 1967; Kobinger and Walland, 1967, 1972a,b). In the initial study on this matter, Kobinger showed that central injections of very low doses of clonidine in the cisterna magna of cats (i.e., in the vicinity of the brainstem) produced hypotension and bradycardia (Kobinger, 1967; Scriabine et al., 1970). The dose used in that study was too low

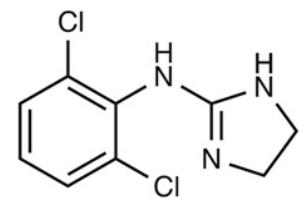

Fig. 1. Chemical structure of clonidine. to induce any cardiovascular effect when injected intravenously. Thus, evidence for the central origin of the unexpected cardiovascular effects of clonidine was provided.

Clonidine, in fact, causes the vasoconstrictive effect for which it was conceived but only when administered intravenously. With this route of administration, the plasma concentration is sufficiently high for clonidine to activate the $\alpha$-adrenergic receptors of the vascular wall, leading to a very transient hypertensive peak lasting less than 2 minutes (Shaw et al., 1971). When administered by any other route (e.g., oral, intramuscular, and a fortiori by direct intracerebral route), clonidine no longer provokes the hypertensive (vasoconstrictive) effect that is observed when administered intravenously. The hypotensive effect of clonidine is produced through sympathoinhibition. Direct recordings of electrical activity on sympathetic nerves, such as the renal and splanchnic nerves, confirmed this fact (Klupp et al., 1970; Dhasmana et al., 1972; Armstrong and Boura, 1973; Bralet and Rochette, 1973; Schmitt and Fénard, 1973a; van Zwieten, 1973).

Thus, the existence of a long-lasting hypotensive effect of central origin not preceded by any hypertensive phase has made clonidine an antihypertensive drug (McRaven et al., 1971). Clonidine was used with success in the 1970s to 1980s in the treatment of primary hypertension (Khan et al., 1970; Hoobler and Sagastume, 1971). At the time, clonidine represented great progress in the treatment of hypertension. Nevertheless, because of its side effects, interest in using clonidine for hypertension has waned and it has been largely replaced by newly marketed drugs that produce fewer side effects compared with clonidine (e.g., sedation, mouth dryness, sexual impotence, and rebound effects upon treatment cessation) (Delbarre and Schmitt, 1973; Cavero et al., 1977). Despite these adverse effects, clonidine is still widely used to treat symptoms due to the sympathetic activation observed during opioid withdrawal (Cottereau et al., 1979; Fantozzi et al., 1980; Gowing et al., 2017).

Because clonidine was designed as an $\alpha$-adrenergic agonist, it was first tempting to propose that the stimulation of such receptors in the CNS could explain its hypotensive and bradycardic effects. Indeed, there are $\alpha$-adrenergic receptors in the CNS. Schmitt was the first to describe that substances known for having $\alpha$-adrenergic antagonist properties are able to prevent the hypotensive effect of clonidine (Delbarre and Schmitt, 1973; Bogaievsky et al., 1974). Of all $\alpha$-adrenergic antagonists used at that time, Schmitt described the blocking properties of the clonidine cardiovascular effects by only two agents: yohimbine and piperoxan. It is interesting to note that the classic $\alpha$-blockers of the time, such as phenoxybenzamine, were not mentioned by 
this Schmitt and Fénard (1973a). At the end of the 1970s, Starke et al. (1977) and Langer et al. (1977) described the existence of two $\alpha$-adrenergic receptor subtype, namely the $\alpha_{1}$ - and $\alpha_{2}$-subtypes, respectively. $\alpha_{2}$-Adrenoceptors were described to be mainly presynaptic in location and involved in the negative feedback control of the release of noradrenaline, the neurotransmitter from the orthosympathetic system, into the synapse (Starke and Endo, 1976; Langer et al., 1977; Miach et al., 1978). At that time, yohimbine and piperoxan were described as compounds selective for $\alpha_{2}$-adrenergic receptors (Bolme et al., 1974; Gold et al., 1978; Hunt et al., 1978; Drew et al., 1979; Guyenet and Cabot, 1981; Rouot et al., 1982). Binding studies also confirmed that clonidine had affinity for $\alpha_{2}$-adrenergic receptors (Greenberg et al., 1976; U'Prichard et al., 1977; Kapur et al., 1979; Rouot and Snyder, 1979).

It is interesting to note that initially the main adverse effects of clonidine and the first-generation derivatives of centrally acting antihypertensive drugs were attributed to the activation of $\alpha_{2}$-adrenergic receptors. This applies particularly to the sedative effects (Cavero and Roach, 1978; Drew et al., 1979). Nevertheless, a new idea germinated very rapidly - that is, to determine whether it was pharmacologically possible to distinguish the hypotensive effects from the unwanted side effects and to develop better tolerated centrally acting drugs for lowering blood pressure (i.e., having less or no sedative effect, the most common side effect of clonidine). During the 1970s to 1980 s, numerous structural analogs of imidazolines were synthesized, both in pharmaceutical companies and in academic pharmacochemistry laboratories (Boudier et al., 1975; Hoefke et al., 1975; Rouot et al., 1976; Leclerc et al., 1980; Stähle et al., 1980). Most often, they were screened according to their ability to activate $\alpha_{2}$-adrenergic receptors, since the $\alpha_{2}$-adrenergic theory dictated the mechanism of the hypotensive action of imidazoline derivatives. The screening tests used were often binding assays relating to specific $\alpha_{2}$-adrenergic binding sites (Kapur et al., 1979; Leclerc et al., 1980; Carenzi et al., 1989). With hindsight, it can now easily be understood why the structural analogs have at best been shown to be hypotensive and sedative as was the lead product, clonidine. By following a different scenario, it was finally possible to discriminate, from a mechanistic point of view, between the favorable effects on blood pressure and the side effects such as sedation.

It must nevertheless be emphasized with this pharmacochemistry approach that it was possible to individualize a second generation of products called "hybrid" agonists. These latter compounds remained able to bind to both $\alpha_{2}$-adrenergic receptors and imidazoline receptors but with a lower affinity for $\alpha_{2}$-adrenergic receptors than that of clonidine, so that their selectivity for imidazoline receptors versus $\alpha_{2}$-adrenergic receptors was more favorable to $\mathrm{I}_{1}$ imidazoline receptors. These compounds, whose prototypes have been widely used in the treatment of hypertension, were moxonidine and rilmenidine (Gomez et al., 1991; Bousquet, 2001; Reid, 2001; Edwards et al., 2012). In agreement with the pharmacological concepts resulting from the above-mentioned research, these drugs have proven to be hypotensive but less sedative than the first-generation products such as clonidine (Bousquet, 2001).

To further study whether the hypotensive effects and side effects could be separated, the first step was to locate the site of action of clonidine and clonidine-like compounds within the CNS. Based on cross-section experiments, it was quickly concluded that the site(s) of action of clonidine was located within the brainstem, which is known to contain many structures involved in the autonomic regulations of cardiovascular functions (Schmitt and Fénard, 1973a; Trolin, 1975).

In the early $1970 \mathrm{~s}$, Bousquet and Guertzenstein (1973) reported that topical applications of a very low concentration of clonidine on a particular area of the ventral surface of the brainstem in cats lowered blood pressure. Beneath the surface of this rostroventral region of the medulla oblongata, there is a small nucleus containing sympathetic neurons, called the nucleus reticularis lateralis (NRL) (Bousquet et al., 1981; Bousquet and Feldman, 1987; Tibiriça et al., 1989, 1991, 1992). This nucleus acts as a vasopressor center, since its blockade by tetrodotoxin, which abolishes neuronal depolarization, leads to a fall in blood pressure (Bousquet et al., 1980). Studies using the microinjection technique (i.e., injection of microvolumes directly into the NRL region by a stereotaxic approach) confirmed that very low doses of clonidine reduce blood pressure (Bousquet et al., 1981; Gatti et al., 1988).

Other groups focused their attention on the nucleus tractus solitarii located in the dorsal part of the medulla oblongata, which acts as the first central relay of the baroreflex arc that has the role of a vasodepressive center (Schmitt and Fénard, 1972, 1973b; Reis et al., 1977; Rockhold and Caldwell, 1979, 1980; Howe, 1985). In very similar studies, it was shown that clonidine could also induce, at least partly, its hypotensive effect from this structure (Laubie et al., 1976; Lipski et al., 1976; Zandberg et al., 1979; Rockhold and Caldwell, 1980; Kubo and Misu, 1981; Vlahakos et al., 1985). However, there was a growing consensus that the NRL played a dominant role among the sites of action for clonidine (Antonaccio and Halley, 1977; Ernsberger and Haxhiu, 1997). From that moment on, studies concerning the pharmacological mechanism of action of clonidine-like compounds could be conducted directly at the site(s) of action of clonidine, leading to more accurate information.

It should be noted that during the same period, Ruffolo et al. (1979a,b,c, 1980a,b) published a series of 
articles, many of which described the differences in effects of substances bearing an imidazoline structure and others with a phenylethylamine structure on $\alpha$-adrenergic receptors. This drew attention to the differences between imidazolines and phenylethylamines, in particular as far as their actions on $\alpha_{2}$-adrenergic receptors were concerned. In this context, a structure-activity relationship study was conducted by using the microinjection technique. In this study, $\alpha$-methylnoradrenaline was used as a reference substance with a phenylethylamine structure and was highly selective for $\alpha_{2}$-adrenergic receptors. $\alpha$-Methylnoradrenaline was not capable of inducing any hypotensive effect when it was directly injected into the NRL, whereas imidazoline compounds reduced blood pressure irrespective of their selectivity for $\alpha_{1^{-}}$or $\alpha_{2}$-adrenergic receptors (Bousquet et al., 1984). It is on this basis that "sites preferring the imidazoline structure" were proposed for the first time (Bousquet et al., 1984). This initial study was followed by radioligand binding studies using membrane preparations from tissues collected in the rostro-ventrolateral region of the human medulla oblongata, which showed that about $80 \%$ of the specific $\left[{ }^{3} \mathrm{H}\right]$ clonidine high-affinity binding was not displaced by various catecholamines such as adrenaline, norepinephrine, and dopamine (Bricca et al., 1988, 1989, 1993, 1994; De Vos et al., 1994; Greney et al., 1994).

At the same time, Reis and colleagues performed similar experiments in the bovine brainstem and showed that $20 \%-30 \%$ of the $\left[{ }^{3} \mathrm{H}\right]$ para-aminoclonidine (PAC) high-affinity binding sites were also resistant to catecholamines (Meeley et al., 1986; Ernsberger et al., 1987). Biochemical confirmation of the existence of specific binding sites for the imidazoline compounds was therefore conclusive. These sites were defined as binding sites sensitive to imidazoline derivatives but insensitive to catecholamines. In fact, for the sake of semantic simplification, Donald Reis named them "imidazoline receptors" instead of "imidazoline-preferring receptors" (Ernsberger et al., 1987). Since then, the entire scientific community interested in these receptors has used this denomination consensually. The principle of this denomination has been modeled onto the benzodiazepine receptors, which also refers to the chemical structure of the compounds that bind to them and that act on them. As far as imidazolines and imidazoline-like compounds are concerned, specific high-affinity binding sites were associated with functions such as sympathetic inhibition and blood pressure reduction.

Together with some other properties such as stereospecificity, this association makes them genuine receptors (Laduron, 1988). Various types of experiments led to the subdivision of the imidazoline receptors into three receptor subtypes: $I_{1}, I_{2}$, and $I_{3}$. Studies of functional pharmacology and/or binding led to this subclassification and the different aspects of these subtypes are discussed later in this review. Subsequently, clonidine was administered to engineered mice whose $\alpha_{2}$-adrenergic receptors were not functional. These experiments confirmed that clonidine can induce a hypotensive effect independently of any action on $\alpha_{2}$-adrenergic receptors (Bruban et al., 2001). However, as far as "hybrid" drugs are concerned, concomitantly targeting imidazoline receptors and $\alpha_{2}$-adrenergic receptors has a synergistic action on blood pressure (Bruban et al., 2002). Nevertheless, an exclusive action on the imidazoline receptors is enough to induce a hypotensive action (Bruban et al., 2002).

Given the fact that a hypotensive effect can be obtained by an exclusive action on imidazoline receptors and that the main adverse effects of clonidine are related to the activation of $\alpha$-adrenergic receptors, it became conceptually possible to design drugs more selective for the imidazoline receptors and thus less active at the $\alpha_{2}$-adrenergic receptors. Structural analogs of clonidine devoid of any effect on $\alpha$-adrenergic receptors are now available. Their potential therapeutic applications are currently being studied. Such compounds could represent a basis for the development of drugs to be used in hypertension and perhaps for other indications, as discussed later in this review (Fellmann et al., 2013a; Gasparik et al., 2015). Once the concept of imidazoline receptors was accepted by a large number of scientists interested in the potential therapeutic effects and uses of drugs targeting these receptors, they were quickly subdivided into three subtypes: $\mathrm{I}_{1}, \mathrm{I}_{2}$ and $\mathrm{I}_{3}$. This classification results from biochemical, pharmacological, and functional characterizations (Vauquelin et al., 1999; Morgan and Chan, 2001; Dardonville and Rozas, 2004; Li et al., 2015). This work will also describe the most recent prospects for $\mathrm{I}_{2}$ and $\mathrm{I}_{3}$ imidazoline receptors and their possible new clinical applications.

\section{Endogenous Imidazoline Receptor Ligands}

As a bona fide receptor, one line of research along the continued study and refinement of imidazoline receptors is to determine and characterize their endogenous ligands, an essential step for improving understanding of this new receptor system. Over the years, several substances have been put forward as endogenous ligands, including clonidine-displacing substance (CDS), harmane, imidazole-4-acetic acid-ribotide (IAA-RP), and agmatine.

\section{A. Clonidine-Displacing Substance}

One of the first articles to suggest the presence of an endogenous ligand was published in the 1980s by Atlas and Burstein (1984). Their work used an extract of bovine brain that when partially purified was able to displace $\left[{ }^{3} \mathrm{H}\right]$ clonidine binding in rat brain membranes. However, this $\left[{ }^{3} \mathrm{H}\right]$ clonidine binding was to $\alpha_{2}$-adrenoceptors, as further work showed that high-performance liquid chromatography (HPLC)-purified CDS extract would compete for $\left[{ }^{3} \mathrm{H}\right]$ yohimbine binding to $\alpha_{2}$-adrenoceptors (Atlas and Burstein, 1984) and also for $\left[{ }^{3} \mathrm{H}\right]$ rauwolscine binding to human platelets (Diamant et al., 1987). Other work demonstrated that 
the extract would displace labeled ligands from $\mathrm{I}_{1}$ and $\mathrm{I}_{2}$ receptors (Ernsberger et al., 1988; Coupry et al., 1990). Further work by Atlas and colleagues used plasma desorption mass spectrometry to determine that CDS had a mass of $587.8 \mathrm{Da}$ and that it was not an amino acid or primary amine compound, as it was ninhydrin and fluorescamine negative in nature (Atlas et al., 1987; Atlas, 1994).

In that same decade, polyclonal antibodies were raised against PAC (Dontenwill et al., 1988) and binding of $\left[{ }^{3} \mathrm{H}\right]$ PAC to the antibody was inhibited by many imidazoline compounds but not by catecholamines. Moreover, $\left[{ }^{3} \mathrm{H}\right]$ PAC binding was inhibited by CDS in a concentrationdependent manner, demonstrating that CDS and these imidazolines were recognizing the same or a similar site on these antibodies (Dontenwill et al., 1988; Meeley et al., 1988). Another polyclonal antibody raised against idazoxan recognized CDS extracted from human serum and cerebrospinal fluid and led to the term "immunoreactive CDS" (Wang et al., 1993). Having a tool that recognizes immunoreactive CDS resulted in elegant studies detailing the presence of CDS in several tissues such as the brain, heart, small intestine, liver, kidney, adrenal gland, and serum (Meeley et al., 1992). It was apparent that this distribution was not similar to the distribution of agmatine in the body and that agmatine might not be the pharmacologically active component of CDS. That the active component of CDS remained a mystery for many years is not that unexpected, as different groups had variations in extraction and purification techniques and also the tissue used as a source of CDS. This mystery was set to be solved to some extent by a more rational approach to comparing CDS from different tissues and comprehensive spectroscopic methods. Initial work by Parker et al. (1999a,b) examined crude methanolic extracts of CDS from bovine lung, brain, and adrenal glands, which were partially purified by reverse-phase HPLC and then assayed for affinity at $\alpha_{2}$-adrenoceptors, $\mathrm{I}_{1}$ receptors, and $\mathrm{I}_{2}$ receptors. Each tissue proved to be a source of CDS. For bovine lung, fraction 21 collected via reverse-phase HPLC contained material that inhibited $\left[{ }^{3} \mathrm{H}\right]$ clonidine binding and corresponded to a peak of absorption at $276 \mathrm{~nm}$ (Parker et al., 1999a,b). In further work, Parker et al. (2000) were also able to extract CDS from NG108-15 cells that also inhibited $\left[{ }^{3} \mathrm{H}\right]$ clonidine binding. One component of CDS was identified as tryptophan, but although present, it was shown to be inactive at displacing $\left[{ }^{3} \mathrm{H}\right]$ clonidine binding or the selective $\mathrm{I}_{2}$ receptor ligand $\left[{ }^{3} \mathrm{H}\right] 2$-(2-benzofuranyl)2-imidazoline (2-BFI) (Hudson et al., 1999b; Parker et al., 1999c). Finally, Parker et al. (2004) refined their techniques further and incorporated electrospray mass spectrometry and ${ }^{1} \mathrm{H}$ NMR to further analyze purified bovine lung CDS. This resulted in the isolation and identification of the $\beta$-carbolines harmane and harmalan (Fig. 2) and revealed them to be biologically active components of CDS having nanomolar affinities at $\mathrm{I}_{1}$ and $\mathrm{I}_{2}$ receptors (Parker et al., 2004).
Although the study by Parker et al. (2004) provides interesting answers to the likely biologic activity of CDS and shows that harmane and harmalan are components of bovine lung CDS, it does not explain how or where these $\beta$-carbolines originated. It is known that $\beta$-carbolines are the condensation products of tryptamine, an indoleamine that has been shown to have moderate affinity for $\mathrm{I}_{2}$ receptors (Hudson et al., 1999b). It is likely that $\beta$-carbolines are formed in vivo via an enzymatically catalyzed Pictet-Spengler reaction (Rommelspacher et al., 1985; Susilo and Rommelspacher, 1987), although oxidation of tetrahydro- $b$-carbolines was shown to form harmane and norharmane is catalyzed by haem peroxidases (Herraiz and Galisteo, 2014), providing more evidence of endogenous production. Much research describes the pharmacology of $\beta$-carbolines, some of which will be discussed in the next section. Although $\beta$-carbolines are an active component of CDS, other active endogenous ligands have also been extracted from CDS (Li et al., 1994).

\section{B. Harmane}

As described above, harmane and harmalan were shown to be pharmacologically active components of CDS and also were shown to have affinity for $\mathrm{I}_{1}$ and $\mathrm{I}_{2}$ receptors (Husbands et al., 2001). However, harmane and several $\beta$-carbolines have a diverse pharmacology binding to several sites, including monoamine oxidase (MAO) as well as serotonin, dopamine, histamine, and benzodiazepine receptors (Glennon et al., 2000; Arib et al., 2010). Some $\beta$-carbolines, including harmane, are found in cooked foods and fermented drinks, and they may be associated with the pathogenesis of essential tremor and may also be involved in clinical conditions such as Parkinson disease and amnesia (Herraiz and Papavergou, 2004; Pfau and Skog, 2004; Laviţă et al., 2016). Despite harmane's pharmacological diversity, it is an attractive prospect as an endogenous ligand for imidazoline receptors. At $I_{1}$ receptors, harmane binds with nanomolar affinity, higher than that of agmatine (Hudson et al., 1999b; Husbands et al., 2001), and injection of harmane into the rat brainstem results in hypotension much like the injections of clonidine.

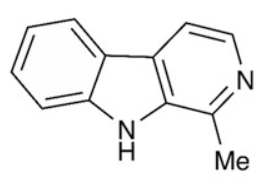

Harmane

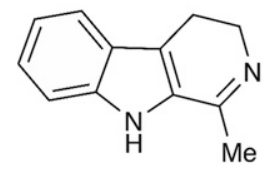

Harmalan

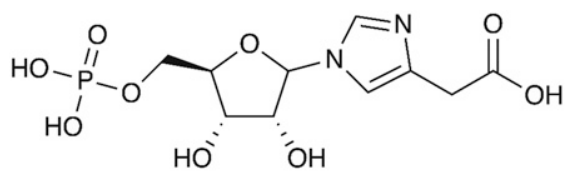

Imidazoleacetic acid-ribotide

Agmatine

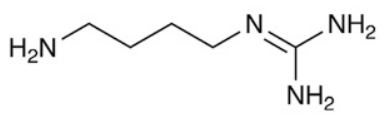

Fig. 2. Chemical structures of candidate endogenous imidazoline receptor ligands harmane, IAA-RP, harmalan, and agmatine. 
Furthermore, these effects are blocked by the $I_{1}$ receptor antagonist efaroxan, indicating a role for harmane in controlling blood pressure (Musgrave and Badoer, 2000). Like several $\mathrm{I}_{2}$ receptor ligands, harmane is a MAO inhibitor and this may represent a mechanism for modulating central monoamine levels (Glover et al., 1982; Lalies et al., 1999). This idea is supported by drug discrimination experiments performed in rats, in which animals trained to recognize 2-BFI and two $\mathrm{MAO}_{\mathrm{A}}$ inhibitors, moclobemide and RO41-1049 [N-(2aminoethyl)-5-(3-fluorophenyl)-4-thiazolecarboxamide hydrochloride], fully substituted for 2-BFI, suggesting shared pharmacological mechanisms of action (MacInnes and Handley, 2002). The same study showed that several $\mathrm{I}_{2}$ receptor ligands, such as BU216 (3-[4,5-dihydroimidaz-2-yl]-quinoline hydrochloride), BU224 (2-[4,5dihydroimidaz-2-yl]-quinoline hydrochloride), BU226 (2-[4,5-dihydroimidaz-2-yl]-isoquinoline hydrochloride), and LSL60101 (2-[2-benzofuranyl]-2-imidazole hydrochloride), and harmane were able to substitute for 2-BFI, whereas $\mathrm{MAO}_{\mathrm{B}}$ inhibitors did not. More support for an association of $\mathrm{I}_{2}$ receptors with $\mathrm{MAO}_{\mathrm{A}}$ was established using in vitro autoradiography in the rat brain (Anderson et al., 2006b). Analysis of the autoradiograms showed a highly significant correlation between the distribution of $\left[{ }^{3} \mathrm{H}\right]$ harmane and $\left[{ }^{3} \mathrm{H}\right] \mathrm{RO} 41-1049$ binding in the CNS and also a significant correlation between the distribution and binding density of $\left[{ }^{3} \mathrm{H}\right]$ harmane- and $\left[{ }^{3} \mathrm{H}\right] 2$-BFI-labeled sites. The study did not rule out the possibility of a small population of $I_{2}$ receptor binding not associated with $\mathrm{MAO}_{\mathrm{A}}$ distribution (Anderson et al., 2006b).

$\mathrm{I}_{2}$ receptor ligands have been shown to alleviate some behaviors associated with naloxone-precipitated morphine withdrawal in rats (Hudson et al., 1999a), and harmane is also able to mimic these affects presumably via $\mathrm{I}_{2}$ receptors (Aricioglu-Kartal et al., 2003). We now know that $I_{2}$ receptors play a role in chronic pain, and harmane is reported to show antinociceptive activity comparable to $\mathrm{I}_{2}$ receptor-selective ligands (Aricioglu et al., 2003; Aglawe et al., 2014). Harmane also binds to $\mathrm{I}_{3}$ receptors located in the pancreas that are involved in the regulation of insulin secretion (Morgan et al., 2003). Although harmane binds to all classes of imidazoline receptor, it is interesting to note that extracts of rat CDS were also shown to stimulate insulin secretion (Chan et al., 1997). However, the ability of harmane to potentiate the glucose-dependent release of insulin from rat and human isolated islets did not entirely match the effects induced by the $\mathrm{I}_{3}$ receptor agonist efaroxan. Morgan et al. (2003) suggested that subtle differences in methodology could have been responsible for the differences seen or that, unlike efaroxan, harmane was able to access an intracellular pool of $\mathrm{Ca}^{2+}$ to mediate some of its effects.

In past studies, the availability of radioactive bioactive molecules has allowed investigation of their potential as putative neurotransmitters by studying their uptake and stimulated release from brain synaptosomes or tissue homogenates. With the availability of $\left[{ }^{3} \mathrm{H}\right]$ harmane, this approach was used to investigate the potential of harmane as the natural modulator or transmitter substance for imidazoline receptors (Abu Ghazaleh et al., 2015a). The uptake of $\left[{ }^{3} \mathrm{H}\right]$ harmane into rat cortical slices was examined and determined to be approximately $450 \mathrm{fmol} / \mathrm{mg}$ protein, greater than the uptake of $\left[{ }^{3} \mathrm{H}\right]$ dopamine and $\left[{ }^{3} \mathrm{H}\right]$ noradrenaline under the same conditions $(260 \pm 43.9$ and $291.4 \pm 56.1 \mathrm{fmol} / \mathrm{mg}$ protein, respectively). [ ${ }^{3} \mathrm{H}$ ] harmane uptake was not affected by monoamine reuptake blockers nor by $\mathrm{I}_{1}$ receptor or $\mathrm{I}_{2}$ receptor ligands. This apparent $\left[{ }^{3} \mathrm{H}\right]$ harmane uptake was not found to be $\mathrm{Na}^{+}$dependent and was unaffected by blockade of the $\mathrm{Na}^{+}-\mathrm{K}^{+}$ATPase pump with ouabain. Transiently elevating $\mathrm{K}^{+}$stimulated the release of stored $\left[{ }^{3} \mathrm{H}\right]$ noradrenaline, $\left[{ }^{3} \mathrm{H}\right]$ serotonin, and $\left[{ }^{3} \mathrm{H}\right]$ dopamine in control superfusion experiments, whereas $\left[{ }^{3} \mathrm{H}\right]$ harmane release was unaffected (Abu Ghazaleh et al., 2015a). Taken together, the results did not support that, under the conditions employed, harmane was acting as a typical neurotransmitter. Work by the same group examined the effect of harmane on $\left[{ }^{3} \mathrm{H}\right]$ monoamine release from rat cortical tissue in vitro and found that harmane $(100 \mu \mathrm{M})$ was able to enhance the $\mathrm{K}^{+}$evoked release of $\left[{ }^{3} \mathrm{H}\right]$ serotonin but not that of $\mathrm{K}^{+}$evoked release of $\left[{ }^{3} \mathrm{H}\right]$ noradrenaline or $\left.{ }^{3} \mathrm{H}\right]$ dopamine (Abu Ghazaleh et al., 2015b).

To date, the other $\beta$-carboline found in CDS (harmalan) has not been widely studied, so its status as a potential endogenous ligand for I receptors is unclear. Although harmane is found endogenously in many tissues, one has to be aware that exogenous sources are a confounder to some extent because $\beta$-carbolines are also present in foodstuffs and fermented beverages (Herraiz and Galisteo, 2003). Evidence demonstrates that harmane is an active constituent of CDS and affects blood pressure via $I_{1}$ receptors, inhibits $\mathrm{MAO}_{\mathrm{A}}$ possibly via $\mathrm{I}_{2}$ receptors, and regulates insulin release via an $\mathrm{I}_{3}$ receptor-mediated process. Despite these attributes, attempts to demonstrate a neurotransmitter role for harmane have to date proved futile, at least in its radiolabeled form. One is reminded of the huge excitement when $\beta$-carbolines, extracted from human urine, were proposed as endogenous ligands for the benzodiazepine receptor and then the subsequent dismay when these substances were found to be an extraction artifact (Braestrup et al., 1980). However, the finding that harmane and several $\beta$-carbolines bind to imidazoline receptors with high affinity remains important and intriguing (Abu Ghazaleh et al., 2015c).

\section{Imidazole-4-Acetic Acid-Ribotide}

IAA-RP (Fig. 2) is derived by ribosylation of IAA in the brain (Prell et al., 2004). IAA, which is an agonist for $\mathrm{GABA}_{\mathrm{A}}$ receptors, has been shown to exist in the rat brain and to be ribosylated to form IAA-RP at micromolar levels in the brain (Prell et al., 2004). 
Most of the observations to support IAA-RP as an endogenous ligand were comprehensively reported by Prell et al. (2004). They found that rat brain extracts contained $1.1 \mu \mathrm{g}$ IAA-RP/g tissue, and neurons of the rostral ventrolateral medulla stained heavily for IAA-RP particularly on neuronal processes. IAA-RP displaced $\left.{ }^{3} \mathrm{H}\right]$ clonidine binding from adrenal medulla $\mathrm{I}_{1}$ receptors with a $K_{\mathrm{i}}$ value of $13 \mu \mathrm{M}$; IAA-RP stimulated $\left[{ }^{3} \mathrm{H}\right]$ arachidonic acid release from PC12 cells in a functional assay. Similarly, IAA-RP had high affinity for brainstem $\mathrm{I}_{1}$ receptors $\left(K_{\mathrm{i}}, 100 \mathrm{nM}\right)$ determined using $\mathrm{p}-\left[{ }^{125} \mathrm{I}\right]$ iodoclonidine as the radioligand. Under conditions in which the $\mathrm{I}_{1}$ binding component was masked, IAA-RP bound to presumed $\alpha_{2}$-adrenoceptors with a $K_{\mathrm{i}}$ of $210 \mu \mathrm{M}$. In a functional assay for $\mathrm{I}_{3}$ receptors, IAA-RP increased insulin secretion from rat and human pancreatic islet cells, an effect blocked by the $\mathrm{I}_{3}$ receptor antagonist KU-14R [2-(2-ethyl-2,3-dihydro-2-benzofuranyl)-1H-imidazole] (Prell et al., 2004). Using crude synaptosomic and vesicleenriched rat brain $\mathrm{P}_{2}$ preparations, $\mathrm{K}^{+}$-evoked release of IAA-RP was shown to be $\mathrm{Ca}^{2+}$ dependent, thus demonstrating that IAA-RP has the characteristics of a neurotransmitter. One surprising finding of this study was that IAA-RP (100 nmol) microinjected into the rat brainstem elevated mean arterial blood pressure, and this effect was reversed by the $\mathrm{I}_{1}$ receptor agonist moxonidine. Overall, Prell et al. (2004) concluded that IAA-RP is a neurotransmitter and may also exhibit hormone-like activity in the periphery. More recently, IAA-RP immunoreactivity has been used to study the distribution of IAA-RP in the rat brain to demonstrate its neuronal location, particularly in structures such as the olfactory bulb, granule cells of the dentate gyrus, and superior colliculus, and it was noteworthy that the distribution of IAA-RP mirrored to some extent that of $\left[{ }^{3} \mathrm{H}\right]$ harmane (Anderson et al., 2006a; Friedrich et al., 2007). An electrophysiological study showed that IAA-RP elicits synaptic depression in rat hippocampal slice preparations in a concentration-dependent manner. This effect was blocked by efaroxan and inhibited to some extent by the $\mathrm{I}_{3}$ receptor antagonist KU-14R, leading Bozdagi et al. (2011) to speculate the involvement of an $\mathrm{I}_{3}$-like receptor as well as $\mathrm{I}_{1}$ receptors. Thus, IAA-RP is present in brain neurons, has functional effects including blood pressure modulation, and in the periphery stimulates release of insulin from the pancreas, making this substance a strong candidate as an endogenous ligand for I receptors.

\section{Agmatine}

The final candidate is agmatine (Fig. 2), a substance that has long been recognized as endogenous to the mammalian body and was proposed by Reis and colleagues as a ligand for I receptors ( $\mathrm{Li}$ et al., 1994). Since then, an enormous amount of research has established agmatine as the front runner in terms of our understanding of a biologic modulator or transmitter substance for I receptors.

Agmatine is synthesized from L-arginine by arginine decarboxylase and hydrolyzed by agmatinase (Reis and Regunathan, 2000). In 2003, the entire proceedings of the fourth international symposium on agmatine and imidazoline systems were published as a single volume in memory of Donald Reis (Annals of the New York Academy of Sciences, Volume 1009). Agmatine was isolated from bovine brain CDS and determined to be present at $1.5-3.0 \mathrm{nmol} / \mathrm{g}$ tissue (Li et al., 1994). It soon became apparent that agmatine was a novel neurotransmitter in the brain, as its synthesis, uptake, vesicular storage, release by depolarization, and subsequent breakdown by agmatinase was demonstrated in the CNS (for review, see Reis and Regunathan, 2000). However, agmatine has a diverse pharmacology and the involvement of I receptors is not always evident (Piletz et al., 2013), particularly because some groups find agmatine to have low affinity for $\mathrm{I}_{1}$ and $\mathrm{I}_{2}$ receptors (Hudson et al., 1999b). For example, agmatine inhibits nitric oxide synthase (Regunathan and Piletz, 2003) and antagonizes $N$-methyl-D-aspartic acid (NMDA) receptors, which may explain the neuroprotective actions of agmatine in rodent models of stroke (Gilad et al., 1996) and glutamate-induced toxicity in cultured rat cerebellar granule cells (Olmos et al., 1999b). Several studies have detailed the effects of agmatine on nociception in rodent models of pain and showed that agmatine enhanced morphine-induced antinociception, an effect mediated through $\alpha_{2}$-adenoceptors and/or I receptors (Aricioglu et al., 2003; Bhalla et al., 2011). However, because agmatine is effective in chronic pain models versus acute models of nociception and selective $\mathrm{I}_{2}$ ligands such as 2-BFI, BU224, and CR4056 [2-phenyl-6-(1H-imidazol1yl) quinazoline] are shown to have therapeutic potential in chronic pain models, $\mathrm{I}_{2}$ receptors rather than $\alpha_{2^{-}}$ adrenoceptors appear to be involved in nociception (Ferrari et al., 2011; Thorn et al., 2016a). In summary, many consider agmatine to be the endogenous ligand for I receptors despite its low affinity for these sites, and much published work favors agmatine over other putative endogenous substances such as IAA-RP or harmane (Piletz et al., 2013; Abu Ghazaleh et al., 2015c).

\section{Imidazoline Subtype 1 Receptors}

\section{A. Definition}

Ernsberger et al. (1993) classified the imidazoline receptors and initiated the terminology " $\mathrm{I}_{1}$ and $\mathrm{I}_{2}$ imidazoline sites." At that time, conclusions were mainly based on data from specific binding experiments using $\left[{ }^{3} \mathrm{H}\right]$ clonidine and $\left[{ }^{3} \mathrm{H}\right]$ idazoxan (Michel and Ernsberger, 1992; Ernsberger et al., 1993). According to this definition, the specific binding sites labeled with tritiated clonidine but resistant to catecholamines 
(i.e., nonadrenergic receptors) were designated as $\mathrm{I}_{1}$ imidazoline receptors by convention.

\section{B. Specific Binding Properties, Selective Ligands, and Tissue and Subcellular Localization}

1. Selective Ligands. Clonidine has been shown to specifically bind to nonadrenergic receptors, particularly non- $\alpha_{2}$-adrenergic receptors, in cell membrane preparations taken from the rostro-ventrolateral part of the brainstem, which contains the main site of the hypotensive action of clonidine (see section II). These clonidine-labeled binding sites themselves are sensitive to other imidazoline compounds or even imidazoles. These imidazoline sensitive binding sites, which are insensitive to catecholamines and even to histamine, are different from those that are labeled by another imidazoline (namely, tritiated idazoxan).

Indeed, idazoxan has a much lower affinity than clonidine for clonidine-labeled sites (Michel and Insel, 1989; Brown et al., 1990; Coupry et al., 1990; Wikberg et al., 1991). These experiments analyzing in detail the binding of tritiated clonidine and that of tritiated idazoxan led to the classification of $\mathrm{I}_{1}$ receptors as having high affinity for tritiated clonidine, whereas $\mathrm{I}_{2}$ receptors are those sites with high affinity for tritiated idazoxan. Clonidine and idazoxan are therefore the two historical markers of the two main classes of imidazoline receptors. Subsequently, many other substances have been used to further investigate specific imidazoline binding. When studied with selective ligands, the specific binding of imidazolines to nonadrenergic receptors was shown to be saturable, reversible, and of high affinity (Greney et al., 1994). ${ }^{125}$ I-labeled para-iodoclonidine was used in a number of studies to characterize the specific binding to $I_{1}$ receptors (Ernsberger et al., 1993). Radiolabeled idazoxan has also been used in attempts to purify the $\mathrm{I}_{1}$ receptor by chromatography (Greney et al., 1997). Ernsberger et al. (1993) showed that there is no correlation between affinities of imidazoline compounds for $\alpha_{2}$-adrenergic receptors and their hypotensive effects in vivo.

Because imidazoline binding sites are responsible for the hypotensive effects of imidazoline substances and of their close derivatives, these specific binding sites can be considered as authentic functional receptors (Gomez et al., 1991; Ernsberger et al., 1993; Bousquet, 2001). Efaroxan is an imidazoline drug that antagonizes the functional effects of clonidine, including its hypotensive effects. This compound does not significantly compete with $\alpha_{2}$-adrenergic receptors (Ernsberger and Haxhiu, 1997); thus, the definition of the $I_{1}$ imidazoline receptors has somewhat improved. It is now a receptor that is sensitive to clonidine and antagonized by efaroxan (Ernsberger and Haxhiu, 1997).

Compound RX82-1002 [2-(2,3-dihydro-2-methoxy1,4-benzodioxin-2-yl)-4,5-dihydro- $1 H$-imidazole hydrochloride] has also been used to mask $\alpha_{2}$-adrenergic receptors in various studies relating to the specific binding of $\left[{ }^{3} \mathrm{H}\right]$ clonidine. As long as very selective ligands of $I_{1}$ receptors were not available, it was necessary to follow a strategy of masking $\alpha_{2}$-adrenergic receptors to study the $I_{1}$ receptors. For example, RX82-1002 was used for this purpose (Bruban et al., 2001). The first ligands thus developed were a series of aminopyrrolines whose first prototypes were LNP509 [cis-/trans-dicyclopropylmethyl-(4,5-dimethyl-4,5-dihydro-3H-pyrrol-2-yl)-amine], LNP906 [2-(5-azido-2-chloro-4-iodo-phenylamino)-5-methylpyrroline], LNP911 [(2-(2-chloro-4-iodo-phenylamino)5-methyl-pyrroline], and LNP599 [3-chloro-2-methyl-phenyl)(4-methyl-4,5-dihydro-3H-pyrrol-2-yl)-amine hydrochloride] (Fig. 3). The most studied was LNP599 because of its pharmacodynamic and pharmacokinetic characteristics, which could make it a lead compound for the development of new therapeutics in the cardiovascular or metabolic field (Gasparik et al., 2015). Details will be provided later in this section.

2. Tissue Distribution. When the binding experiments were carried out with mixed ligands (i.e., capable of binding to both $\alpha_{2}$-adrenergic receptors and imidazoline receptors), it was necessary to follow the strategies of avoiding or eliminating the binding to $\alpha_{2}$-adrenergic receptors so to focus only on binding to $\mathrm{I}_{1}$ imidazoline receptors. In fact, two strategies have been used: namely, the masking of $\alpha_{2}$-adrenergic receptors by a specific and selective ligand of these receptors, such as $\alpha$-methylnoradrenaline or rauwolscine, or using membrane preparations from cells that do not express $\alpha_{2}$-adrenergic receptors but only $I_{1}$ imidazoline receptors, as is the case of chromaffin cells of the adrenal gland (PC12 line). Thus, it has been demonstrated that moxonidine, a second-generation ligand, was more selective for $\mathrm{I}_{1}$ than for $\alpha_{2}$-adrenergic receptors compared with clonidine (Regunathan et al., 1991b; Wang et al., 1992).

$\mathrm{I}_{1}$ binding sites were found in the bovine brainstem (Ernsberger et al., 1987, 1988; Bricca et al., 1989) and<smiles>CC1CCC(Nc2cc(N)c(I)cc2Cl)=N1</smiles>

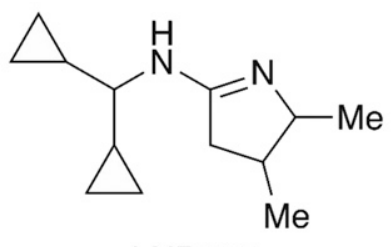

LNP509

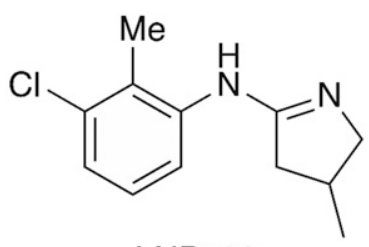

LNP599
Fig. 3. Chemical structures of aminopyrrolines of interest LNP911, LNP906, LNP509, and LNP599. 
also in the human, rabbit, and rat brain (Bricca et al., 1989, 1993). Similar observations were made by Kamisaki et al. (1990) in rat brains and by Ernsberger et al. (1987) in neurons taken from the ventrolateral portion of the bovine brainstem.

Although most of the imidazoline receptor autoradiography experiments published to date have been devoted to $\mathrm{I}_{2}$ receptors, some studies have used $\mathrm{I}_{1}$ ligands. King et al. (1995a,b,c) used $\left[{ }^{3} \mathrm{H}\right]$ idazoxan, $\left[{ }^{3} \mathrm{H}\right]$ para-aminoclonidine, and $\left[{ }^{3} \mathrm{H}\right]$ rilmenidine to describe sites corresponding to the definition of specific $\mathrm{I}_{1}$ binding sites in the kidney and brain of rats. De Vos et al. (1994) used $\left[{ }^{3} \mathrm{H}\right]$ idazoxan to differentiate imidazoline receptors from $\alpha_{2}$-adrenergic receptors in the human CNS (De Vos et al., 1994). Using $\left[{ }^{3} \mathrm{H}\right]$ paraaminoclonidine and $\left[{ }^{3} \mathrm{H}\right]$ idazoxan, MacKinnon et al. (1993) showed the existence of $\mathrm{I}_{1}$ binding sites in the rat kidney and also $\mathrm{I}_{2}$ binding sites under $\alpha_{2}$-adrenergic receptor masking conditions. MacKinnon et al. (1993) found some differences, notably in the receptor density that was lower in the kidney than in the human and bovine brain. In a study of membrane preparations from proximal tubular cells of rabbit using $\left[{ }^{3} \mathrm{H}\right]$ idazoxan, specific $I_{1}$ binding sites were found in this particular region of the kidney (Gargalidis-Moudanos and Parini, 1995). Escribá et al. (1994) achieved immunodetection of imidazoline receptors in the rat brain and the human brain in particular.

Imidazoline binding sites were also found in the rat kidney (Ernsberger et al., 1990), in human platelets (Piletz et al., 1991), in chromaffin cells of the adrenal gland (Separovic et al., 1996), as well as in cat and rabbit carotid sinuses (Kou et al., 1991). Piletz and Sletten (1993) characterized $I_{1}$ imidazoline receptors on human and rabbit platelets. They showed in binding experiments in human platelets that in addition to the classic $\alpha_{2}$-adrenergic binding of this ligand, the $\left[{ }^{3} \mathrm{H}\right]$ $\mathrm{PAC}$ radioligand also binds to nonadrenergic sites corresponding to the definition of $\mathrm{I}_{1}$ imidazoline receptors (Piletz et al., 1991). In addition, specific $\mathrm{I}_{1}$ binding sites have been described in the dog prostate gland (Felsen et al., 1994).

There are no detectable $\mathrm{I}_{1}$ receptors in cardiovascular tissues, including the heart; thus far, only $\mathrm{I}_{2}$ receptors have been found. However, Ernsberger et al. (1998) showed, with para-iodoclonidine, that there are $\mathrm{I}_{1}$ receptors in the carotid bodies. Nevertheless, using the binding technique, $\mathrm{I}_{1}$ imidazoline receptors were shown to be present in the atria and ventricles of rat hearts (El-Ayoubi et al., 2002, 2004). Several teams have shown the existence of imidazoline binding sites in adipocytes of different species, including the hamster and rat (MacKinnon et al., 1989; Langin et al., 1990; Fellmann et al., 2013b; Weiss et al., 2015). Weiss et al. (2015) demonstrated the existence of specific $\mathrm{I}_{1}$ binding sites of imidazolines in hepatic cell lines, and Molderings et al. (1995) also found fairly abundant amounts in the rat stomach. In summary, the expression of the specific $I_{1}$ binding sites is rather ubiquitous and concerns mainly the CNS but also the digestive and endocrine system, cardiovascular system, and adipose tissue.

3. Subcellular Distribution. In a study performed on membrane preparations from neurons taken from the ventrolateral part of the brainstem by a discontinuous sucrose density gradient, Ernsberger and Shen (1997) showed that $I_{1}$ receptors were predominantly on nonmitochondrial membranes. This localization differentiates them clearly from $\mathrm{I}_{2}$ receptors (Ernsberger and Shen, 1997). Heemskerk et al. (1998) subsequently showed that high-affinity $\mathrm{I}_{1}$ receptors in bovine brain tissue are particularly expressed by synaptic membranes, and most likely from presynaptic terminals. Although another team observed a partial mitochondrial localization of $I_{1}$ receptors, it nevertheless confirmed that the highest expression levels were in the plasma membrane fractions in the rat cerebral cortex (Hosseini et al., 1998). Keller and García-Sevilla (2015) used immunodetection to localize $I_{1}$ receptors in the membrane fractions of mouse and human brains. As can be seen, subcellular localization studies are relatively few, but they all converge toward a major localization on the plasma membranes for the expression of these receptors, a location very different from that of the $\mathrm{I}_{2}$ receptors, which will be detailed later in this review.

4. Second-Generation Imidazoline Subtype 1 Receptor Ligands. To achieve the second-generation central antihypertensive drugs moxonidine and rilmenidine, various substitutions were made on the aromatic part of the imidazoline molecule in the case of moxonidine and on the oxazoline structure instead of an authentic imidazoline structure in the case of rilmenidine (Bricca et al., 1989).

The antihypertensive moxonidine is a second-generation $I_{1}$ receptor-selective drug, with a 10 - to 700 -fold greater affinity for $\mathrm{I}_{1}$ receptors than for $\alpha_{2}$-adrenergic receptors (Ernsberger et al., 1993). Similarly, rilmenidine was developed for the same purposes and is, like moxonidine, used as an antihypertensive drug with fewer adverse effects, particularly sedation (Reid, 2001).

Tritium-labeled moxonidine and rilmenidine have also been used as markers for $\mathrm{I}_{1}$ receptors in various experimental studies (King et al., 1992, 1993, 1995c, 1998). The development of imidazoline-like drugs, which were more selective for $I_{1}$ receptors than for $\alpha_{2}$-adrenergic receptors, demonstrated that modifications of the chemical structure could improve this selectivity. Then, new pharmacochemistry projects were developed to further improve this selectivity through structure-activity relationship analysis. Thus, a chemical series of pyrroline compounds has been exploited and tested for biologic activities and also for its specific binding properties.

In this pyrroline series, LNP509, which is a dicyclopropyl-methyl-pyrrol-amine, was the first to have no detectable affinity for $\alpha_{2}$-adrenergic receptors but was 
still able to lower blood pressure after central administration (Schann et al., 2001). This validated the concept that substances with neither activity nor affinity for $\alpha_{2^{-}}$ adrenergic receptors were nevertheless capable of lowering blood pressure by sympathetic inhibition. Another structural modification also led to the development of substances that are highly selective for $\mathrm{I}_{1}$ receptors and induce hypotensive activity even after intravenous administration. These are methylated derivatives on the heterocyclic group; the prototype in this case was LNP630 [(2,6-dichloro-phenyl)-(4-methyl-4,5-dihydro$1 H$-imidazol-2-yl)-amine] (Schann et al., 2012). From this ligand, compounds were formulated to try to develop substances that could lead to new centrally acting antihypertensive drugs that were better tolerated than first-generation drugs. Thus, new molecules of the 2-arylimino-pyrrolidine family have been proposed. In this series, the LNP599 molecule has a nanomolar affinity for $\mathrm{I}_{1}$ receptors, has no detectable affinity or activity for the $\alpha_{2}$-adrenergic receptor, and decreases blood pressure at relatively low doses regardless of the route of administration. This molecule serves as a prototype for development of new drugs to treat hypertension or the metabolic syndrome. This perspective will be detailed later in this review (Gasparik et al., 2015).

5. Selective Imidazoline Subtype 1 Receptor Ligands with High Affinity as Pharmacological Probes. For the purposes of biochemical investigations concerning imidazoline receptors, the development of molecules with a very high affinity and selectivity for the $\mathrm{I}_{1}$ receptors has been a priority. In the pyrroline series, LNP911 was the first molecule that exhibited very high affinity for $I_{1}$ receptors and a very high selectivity for $\mathrm{I}_{1}$ receptors over $\alpha_{2}$-adrenergic receptors (Greney et al., 2002). Subsequently, a photoactivatable function has been added in the LNP906 structure to irreversibly label the $\mathrm{I}_{1}$ receptor with high affinity. LNP906 has also been shown to be an $\mathrm{I}_{1}$ receptor antagonist. These two substances, LNP911 and LNP906, have been used to study the $I_{1}$ receptors (Greney et al., 2002; Urosevic et al., 2004). The entire range of compounds needed to study the target receptors is now available, and they are also useful to explore hypotheses for the development of new drugs.

6. Receptor-Receptor Interactions. As early as the mid-1990s, Hieble and Ruffolo (1995) suggested the existence of possible interactions between $\mathrm{I}_{1}$ receptors and $\alpha_{2}$-adrenergic receptors and wondered about the possible effects of multiple interactions between receptors and between agonists and antagonists on both types of receptors. Greney et al. (2000) used different cell lines, one expressing only $\alpha_{2}$-adrenergic receptors (HT29 cells), a second line expressing only $\mathrm{I}_{1}$ receptors (PC12 cells), and a third one expressing both of them (NG10815 cells). These authors showed that both receptors are individualized entities, but they can couple to the same cAMP transduction pathway. Thus, interactions between the $\mathrm{I}_{1}$ receptors and the $\alpha_{2}$-adrenergic receptors may occur at least at the level of transduction pathways that they have in common (Greney et al., 2000). Shortly afterward, Bruban et al. (2002) showed that a $\alpha_{2}$-adrenergic agonist and a selective $I_{1}$ receptor agonist, devoid of any affinity for $\alpha_{2}$-adrenergic receptors, synergistically lower blood pressure, suggesting functional interaction(s) between the two types of receptors. In this work, LNP509 was the $\mathrm{I}_{1}$ receptor agonist used, whereas $\alpha$-methyl-noradrenaline was the reference $\alpha_{2}$-adrenergic agonist (Bruban et al., 2002). Chen et al. (2003) performed a study on Chinese hamster ovary cells expressing human $\alpha_{2}$-adrenergic receptors transfected with cDNA encoding human imidazoline receptor antisera-selected (IRAS) protein (a candidate protein of the $\mathrm{I}_{1}$ receptor). In these modified cells expressing both types of receptors, Chen et al. (2003) also showed an interaction between the two types of receptors. In summary, although the effects of molecular mechanisms beyond the interactions between $\mathrm{I}_{1}$ receptors and $\alpha_{2}$-adrenergic receptors are not yet fully elucidated, this interaction is presently strongly supported by experimental data.

Nevertheless, additional receptor-receptor interactions have also been proposed. A cannabinoid agonist, WIN52212-2 [(R)-(+)-[2,3-dihydro-5-methyl-3-[(4-morpholino)methyl]pyrrolo-[1,2,3-de]-1,4-benzoxazin-6yl](1-naphthyl)methanone; phenyzoline,4,5-dihidro2 -(2-phenylethyl)- $1 H$-imidazole], and agmatine used as an imidazoline receptor agonist could reduce central temperature by a synergistic mechanism in rats (Rawls et al., 2006). A similar synergistic interaction between agmatine and cannabinoid agonists was observed for their antinociceptive effects in the hot plate test (Aggarwal et al., 2009). Also in the field of antinociceptive effects, Stone et al. (2007) showed that there is a possible synergy between $\mathrm{I}_{1}$ receptors and opioids at the spinal level based on the selective $I_{1}$ receptor agonist, diethyl-phenyl-amino-imidazoline, ST91 [2-(2,6-diethylphenylamino)-2-imidazoline hydrochloride] (Stone et al., 2007). Boxwalla et al. (2010) showed that an endothelin receptor antagonist is able to potentiate the antinociceptive effects of clonidine, indicating a negative interaction between endothelin receptors and imidazoline receptors. Chan and Morgan (1998) showed that two potent $\sigma$ receptor agonists were able to increase insulin secretion from on islets of Langerhans isolated from rats. They studied the possible interaction between $\sigma$ receptors and the imidazoline receptors (possibly of the $I_{1}$ receptor) by using an $I_{1}$ receptor antagonist efaroxan, and they suggested the existence of complex interactions of these two types of receptors at the pancreatic level (Chan and Morgan, 1998). Experiments were performed in rats using selective NMDA and $\alpha$-amino-3-hydroxy-5-methyl-4-isoxazolepropionic acid (AMPA)/kainate receptor antagonists and the $\mathrm{I}_{1}$ receptor agonists clonidine and moxonidine (Wang et al., 2007). The glutamate receptor antagonists abolished the hypotensive actions of clonidine and 
even its actions on heart rate. Wang et al. (2007) therefore suggested the existence of an interaction between the imidazoline receptors and the glutamate receptors.

7. Transduction Mechanisms. As expected, the hypothesis of a coupling of the $\mathrm{I}_{1}$ receptors with $\mathrm{G}$ proteins has been the subject of the greatest number of investigations. Regunathan et al. (1991a) explored this hypothesis using adrenal chromaffin cells of bovine origin. Clonidine did not alter basal or forskolin-stimulated cAMP production, nor did it alter the hydrolysis of basal, guanosine $5^{\prime}-3-O$-(thio) triphosphate-stimulated, or carbachol-stimulated phosphoinositide hydrolysis. In contrast, clonidine increased cGMP production and calcium uptake. Regunathan et al. (1991a) concluded from this seminal study that $\mathrm{I}_{1}$ receptors did not appear to be coupled to a second messenger system involving classic $G$ proteins. Other studies quantified the densities of different $G$ proteins in platelets of patients with depression to analyze possible associations with the expression of imidazoline receptors (García-Sevilla et al., 1996). Positive correlations were found between the immunoreactivity of $I_{1}$ receptors and either $G_{\alpha \alpha / 11}, G_{\alpha i 2}$, or $G_{\beta}$ proteins. The correlation with $\mathrm{G}_{\alpha \mathrm{q} / 11}$ protein suggested that $I_{1}$ receptors could be coupled to a phosphoinositide pathway at least in platelets (García-Sevilla et al., 1996). Thus, a transduction mechanism in the platelets of patients with depression (i.e., the phosphoinositide pathway) that does not exist in chromaffin cells has been described. The question of a possible coupling mechanism of $\mathrm{I}_{1}$ receptors with $\mathrm{G}$ proteins was reanalyzed by Takada et al. (1997). These authors were interested in a possible involvement of $\mathrm{G}$ proteins sensitive to pertussis toxin, and they analyzed the effects of the toxin on the antiarrhythmic actions of various agonists and antagonists for either $\alpha_{2}$-adrenergic receptors or selective for the $\mathrm{I}_{1}$ receptors in a rat model of arrhythmias induced by the halothane-adrenaline mixture. They observed that the arrhythmogenic effect of adrenaline was prevented by rilmenidine and that this action was completely blocked by pretreatment with pertussis toxin. The same applied for dexmedetomidine, a selective $\alpha_{2}$-adrenergic agonist, suggesting that both types of receptors could be functionally coupled to $G$ proteins sensitive to pertussis toxin (Takada et al., 1997). Greney et al. (2002) also took up this question and showed that a selective $\mathrm{I}_{1}$ receptor agonist, benazoline, reduced cAMP levels stimulated by forskolin in rat pheochromocytoma (PC12) cells, but this effect was insensitive to pertussis toxin. It therefore seems that at least for these $G$ proteins sensitive to pertussis toxin, the situation may be variable depending on the tissues or cells studied. In addition, two teams focused their attention on the possible effects of selective $I_{1}$ receptor agonists on phosphatidylcholine-selective phospholipase $\mathrm{C}$ activity in PC12 cells, which do not express $\alpha_{2}$-adrenergic receptors, and in cells from the rostro-ventrolateral region of the medulla oblongata. Thus, Separovic et al. (1997) showed that moxonidine caused an accumulation of diacylglycerides and released tritiated phosphocholine in cells previously labeled with tritiated clonidine. These effects were blocked by a PC-PLC inhibitor. These results demonstrated the involvement of PC-PLC in the effects resulting from the stimulation of $\mathrm{I}_{1}$ receptors (Separovic et al., 1997). This hypothesis was echoed by Zhang et al. (2001) who observed that activation of phosphatidylphospholipase $\mathrm{C}$ by $\mathrm{I}_{1}$ receptors in the PC12 cell line could result in secondary phosphorylation of a mitogenactivated protein kinase (MAPK). Similar results were later described with a protein considered as a candidate for the $I_{1}$ receptor (i.e., IRAS protein) (Zhang and AbdelRahman, 2005). The fact that this transduction mechanism involves PC-PLC and extracellular signal-regulated kinase (ERK) provides support for the similarity between this IRAS and the $\mathrm{I}_{1}$ receptor and immunohistochemistry confirms that the major site of hypotensive action of rilmenidine was in the medulla oblongata. It should be noted that in these experiments, the $\mathrm{I}_{1}$-selective antagonist efaroxan antagonized the effect induced by rilmenidine. This study showed that, as in PC12 cells, ERK1/2 MAPK (p42/44) appears to be involved in effects mediated by the activation of $I_{1}$ receptors in brain tissue (Zhang and Abdel-Rahman, 2005). Edwards et al. (2001) used moxonidine as an $\mathrm{I}_{1}$ receptor agonist in PC12 cells and showed that ERK and c-Jun N-terminal kinase were activated by the treatment and could therefore play a role in the signaling pathways coupled to $I_{1}$ receptors. Edwards et al. (2001) suggested that these receptors may also play a role in cell growth.

The same team also showed that the activation of $I_{1}$ receptors can abolish the nerve growth factor-activated signaling pathway by increasing the levels of a specific phosphatase through ERK dephosphorylation (Edwards and Ernsberger, 2003). Yamanaka et al. (2010) investigated the possible involvement of the phosphatidylinositol 3-kinase/Akt signaling pathway in the antiarrhythmic effects of the centrally administered $\mathrm{I}_{1}$ receptor agonist, rilmenidine. The results of this study showed that the pertussis toxin-sensitive $\mathrm{G}$ protein, phosphatidylinositol 3kinase/Akt GSK3 $\beta$, is coupled with $\mathrm{I}_{1}$ receptors (Yamanaka et al., 2010). Weiss et al. (2015) showed that a ligand selective for $\mathrm{I}_{1}$ receptors, LNP509, was able to increase the phosphorylation of $5^{\prime}$ adenosine monophosphate-activated protein kinase (AMPK) in hepatic cells. AMPK is involved in cellular energy homeostasis. In case of low cellular energy, AMPK increases glucose and fatty acid uptake and oxidation. This activation of the AMPK pathway could explain, at least partially, the favorable effect of $\mathrm{I}_{1}$ receptor activation on insulin sensitivity (Weiss et al., 2015). In a study of the effects of $I_{1}$ receptor activation by moxonidine on the development of hepatic fibrosis, Zhang et al. (2017) showed that $I_{1}$ receptor activation negatively regulates the course of hepatic fibrosis in an Nrf2-dependent pathway. Indeed, both in vivo and in vitro, moxonidine activated Nrf2 signaling, whereas knockout or knockdown of Nrf2 enhanced the antifibrotic and anti-inflammatory effects of moxonidine (Zhang et al., 2017). 
Based on a fairly wide range of experimental models involving various species, tissues, and cell lines, it appears that $I_{1}$ receptors may couple to several transduction mechanisms involving $\mathrm{G}$ proteins, the cAMP pathway, phospholipase C-selective phosphatidylcholine, MAPKs (ERK1/2 and c-Jun N-terminal kinase), mitogen-activated protein kinase phosphatase 2 phosphatase, and even nitric oxide. $\mathrm{I}_{1}$ receptors have been described in various peripheral tissues, including the liver, kidney, and adipose tissue. Now, there is evidence in favor of intracellular functions associated with these receptors, and $\mathrm{I}_{1}$ receptor-selective ligands, at least those that are sufficiently lipophilic to cross the plasma membrane, can target these cytoplasmic receptors. Thus, there is presently experimental evidence that, in addition to transmembrane $I_{1}$ receptors, intracellular $I_{1}$ receptors exist in various peripheral tissues and may be associated with metabolic functions.

8. Attempts to Clone Imidazoline Subtype 1 Receptors. Polyclonal antibodies have been developed in rabbits that specifically label a $70-\mathrm{kDa}$ protein that binds $\mathrm{I}_{1}$ receptor-selective ligands. This protein, capable of binding labeled idazoxan, was purified from solubilized bovine chromaffin cell membranes by affinity chromatography (Escribá et al., 1994). With these antibodies, a cDNA clone isolated from a human hippocampus cDNA library encoded transcripts of 6 and $9.5 \mathrm{~kb}$. The 6 -kb mRNA was enriched particularly in the brain and endocrine glands compared with other tissues (Piletz et al., 2000), and in situ hybridization showed enrichment of this mRNA in neurons of rat hippocampus and also in the cerebellar cortex. The protein encoded by this cDNA has been proposed as the I1 receptors (Piletz et al., 2000). Piletz et al. (2000) also showed that the IRAS-selected cDNA-1 (IRAS-1) encodes a 267-kDa protein that was immunologically consistent with the $\mathrm{I}_{1}$ receptor protein, and significant correlation was observed between total IRAS mRNA and $B_{\max }$ values ( $\mathrm{I}_{1}$ receptor density in different rat tissues). However, the amino acid sequence of IRAS is different from that of the transmembrane $I_{1}$ receptors. Mouse IRAS was identified with nisharin (Alahari et al., 2000; Sun et al., 2007), which is an intracellular protein that plays a role in regulating cell structure. The same group reported that nisharin is involved in the brainstem control of blood pressure (Maziveyi and Alahari, 2015). The fact that this protein has an intracellular localization is quite consistent with the described actions of imidazoline-like compounds on transduction pathways involving AMPK or Nrf2 (see above). Zhang and Abdel-Rahman (2008) also showed that inhibition of nisharin expression decreases the hypotensive effect of rilmenidine.

\section{Cellular Effects}

Here only the main effects that were not addressed in section IV.B.7 and that may contribute to effects observed in vivo or may be of interest in the future will be mentioned.
1. Imidazoline Subtype 1 Receptors and Apoptosis, Cell Viability, Growth, and Proliferation. The effects of a selective $\mathrm{I}_{1}$ receptor agonist on apoptosis in PC12 cells appears to be complex and depends on the experimental model of apoptosis. Thus, benazoline had a facilitating effect on apoptosis in the serum deprivation model, whereas it had a protective action in the model of induction of apoptosis by tumor necrosis factor $\alpha$ (TNF- $\alpha$ ). In both cases, the use of a selective $\mathrm{I}_{1}$ receptor antagonist confirmed that these effects involved $I_{1}$ receptors (Dupuy et al., 2004). Molderings et al. (2007) demonstrated in PC12 cells that moxonidine and also agmatine have an antiproliferative effect linked to their action on $\mathrm{I}_{1}$ receptors, but they also involve receptors of the S1P family. McLean et al. (2014) confirmed that another selective $\mathrm{I}_{1}$ receptor agonist, S43126 (2-[40-methoxyphenyl]-4,5-dihydro- $1 H$-imidazole), has an antiproliferative effect on PC12 cells. Using cardiomyocytes from rat neonates, the selective $\mathrm{I}_{1}$ receptor agonist moxonidine protects against cell death induced by starvation or by interleukin-1b (Aceros et al., 2014). In summary, it appears that the activation of $I_{1}$ receptors most often has a protective effect on cell viability.

2. Imidazoline Subtype 1 Receptors and Insulin and Adiponectin. Using insulin-secreting Min6 $\beta$-cells Tesfai et al. (2012) showed that $I_{1}$ receptor activation with a selective $I_{1}$ receptor ligand, $S 43126$, had a glucosedependent insulinotropic action; this effect was prevented by efaroxan, a selective $\mathrm{I}_{1}$ receptor antagonist. Weiss et al. (2015) showed that activation of $I_{1}$ receptors on tissues targeted by insulin (i.e., liver and adipose tissues) also led to an improvement in insulin sensitivity. LNP599, a compound highly selective for $I_{1}$ receptors, stimulates the secretion of adiponectin by 3T3-L1 adipocyte cultures (Fellmann et al., 2013a; Weiss et al., 2015). In addition to the work just mentioned, Yang et al. (2012) observed on these same cells that a selective $I_{1}$ receptor agonist can increase the expression of farnesoid $\mathrm{X}$ nuclear receptors and thus improve hepatic steatosis. This effect appears to be due to an increase in intracellular calcium and an increase in p38 phosphorylation. An improvement in hepatic steatosis was also observed in vivo in mice treated with rilmenidine (Yang et al., 2012).

$\mathrm{I}_{1}$ receptor activation negatively regulates the progression of fibrosis through a Nrf2-dependent pathway in hepatic stellate cells. This hepatic $\mathrm{I}_{1}$-dependent antifibrotic action was also observed in vivo in mice (Zhang et al., 2017). In human platelets, when $\alpha_{2^{-}}$ adrenergic receptors are blocked by yohimbine, the addition of dexmedetomidine (a $\alpha_{2}$-adrenergic agonist $/ \mathrm{I}_{1}$ receptor agonist) was actually found to suppress ADPinduced platelet aggregation, and this effect was blocked by efaroxan, an $\mathrm{I}_{1}$ receptor-selective antagonist. The specific activation of $I_{1}$ receptors thus leads to an interesting platelet antiaggregation effect (Kawamoto et al., 2015).

3. Imidazoline Subtype 1 Receptors and Neurons. In rats, immunohistochemistry showed an increase in ERK1/2 (p42/44) MAPK in the ventrolateral part of the 
brainstem associated with the hypotensive effect of rilmenidine and this effect was abolished by efaroxan (Zhang and Abdel-Rahman, 2005). In a whole-cell patchclamp study performed on rat dorsal striatum slices, moxonidine significantly decreased $\mathrm{GABA}_{\mathrm{A}}$ receptormediated inhibitory postsynaptic currents through the involvement of presynaptic $\mathrm{I}_{1}$ receptors (Tanabe et al., 2006). In organotypic cultures of mouse hippocampal slices, dexmedetomidine had a postconditioning effect dependent on $\mathrm{I}_{1}$ receptors (Dahmani et al., 2010).

Once again, the cellular effects on neurons implicating $I_{1}$ receptors appear complex and depend much on the localization within the CNS.

\section{Imidazoline Subtype 1 Receptors and In Vivo Effects}

Here we will only discuss the effects that have been repeatedly documented in the scientific literature. Obviously, the cardiovascular and metabolic effects largely dominate the picture.

1. Effects on Blood Pressure and Heart Rate. Effects on blood pressure and heart rate were analyzed in detail in section I. It is accepted that all $\mathrm{I}_{1}$ receptor agonists that are sufficiently lipophilic to cross the blood-brain barrier reduce arterial pressure and heart rate in all mammalian species tested, including humans, effects that are mediated by a central sympathoinhibitory action. According to Mahmoudi et al. (2018), $\mathrm{I}_{1}$ receptor agonists may have interesting clinical applications in hypertensive patients with intracerebral hemorrhage by reducing post-intracerebral brain injury. This hypothesis is based on the fact that not only do these drugs allow the control of hypertension, but they also have a set of potential effects (e.g., anti-inflammatory, antiedematous, anti-inflammatory, and antiapoptotic effects) that can circumvent posthemorrhagic complications (Mahmoudi et al., 2018).

2. Antiarrhythmic Effects. Cardiac antiarrhythmic effects of $I_{1}$ receptor agonists have been observed in several species, in several experimental models, and with various $\mathrm{I}_{1}$-selective drugs. Thus, Leprán and Papp (1994) observed a protective effect of moxonidine against arrhythmias induced by myocardial ischemia in rats; this beneficial effect extended even to the reperfusion period. Rilmenidine has a protective effect against bicuculline-induced cardiac arrhythmias in rabbits (Roegel et al., 1996, 1998). Rilmenidine and dexmedetomidine have protective effects against adrenalineinduced arrhythmias in halothane anesthetized dogs (Kamibayashi et al., 1995; Mammoto et al., 1995, 1996). In the same experimental model in rats, moxonidine and rilmenidine are also clearly protective (Kagawa et al., 2005; Yamanaka et al., 2010). Similarly, moxonidine is protective against ouabain-induced arrhythmias in guinea pigs (Mest et al., 1995). In a model of neurogenic arrhythmias induced by electrical stimulation of the posterior hypothalamus, moxonidine also exerts a significant protective effect in rabbits (Poisson et al., 2000). In summary, the antiarrhythmic properties associated with the activation of $I_{1}$ receptors are amply documented.

3. Effects in Congestive Heart Failure. In a clinical study of 32 patients with class III congestive heart failure according to the New York Heart Association classification, moxonidine was administered in single doses of 0.4 or $0.6 \mathrm{mg}$ per patient compared with placebo. Moxonidine caused a modest vasodilator effect accompanied by a significant reduction in systemic and pulmonary arterial pressures as well as a reduction in the plasma concentration of noradrenaline (Swedberg et al., 2000). Unfortunately, this effect of moxonidine was not confirmed in the MOXCON clinical trial, which involved chronic treatment of patients with fairly severe heart failure. In this trial, the sympathetic activity was probably inhibited too much in patients who, at this advanced stage, require sympathetic activity (Cohn et al., 2003; Pocock et al., 2004). In the hamster model of cardiomyopathy, moxonidine improved cardiac performance by both central and direct cardiac sympathoinhibitory actions (Stabile et al., 2011). The same team showed that moxonidine prevents left ventricular hypertrophy and cardiac remodeling in hypertensive rats and in hamsters with cardiomyopathy (MukaddamDaher, 2012). Therefore, despite interesting experimental observations, moxonidine did not display efficacy in patients with congestive heart failure. Two possible contributors to this finding involve too intense sympathoinhibition with respect to the disease severity in the patients tested and the insufficient selectivity of the test drug, moxonidine, for the $\mathrm{I}_{1}$ receptors.

4. Effects on Glucose and Lipid Metabolism and Interest in Metabolic Syndrome. The group of symptoms consisting of arterial hypertension and at least two of the following abnormalities (i.e., insulin resistance, hyperlipidemia, obesity, or at least overweight) form what is now called the metabolic syndrome (Fellmann et al., 2013a). This syndrome is known to be associated with high cardiovascular risk in patients (Mongraw-Chaffin et al., 2018).

In rats with fructose-induced insulin resistance, moxonidine completely prevented the development of insulin resistance, hyperinsulinemia, and hypertension (Ernsberger et al., 1999). Spontaneously hypertensive obese (SHROB) rats have a faK mutation of leptin receptors that naturally attenuates them. SHROB rats exhibit hypertension, glucose intolerance, and insulin resistance. In SHROB rats, chronic treatment with moxonidine reduced blood pressure and improved glucose intolerance. It also decreased fasting insulin and free fatty acids (Ernsberger et al., 1999). Koletsky et al. (2003) also achieved similar results with rilmenidine in SHROB rats, with a reduction in triglycerides and cholesterol (Velliquette et al., 2006; Niu et al., 2011). In another model of metabolic syndrome (high-fat diet-induced 
obesity), clonidine and rilmenidine had similar beneficial blood pressure and metabolic effects that were accompanied by a reversal of microvascular rarefaction in skeletal muscles and in the heart (Nascimento et al., 2016). It is interesting to note that under acute conditions, moxonidine and rilmenidine cause hyperglycemia, but less than that induced by clonidine in the same experimental conditions. The acute effects were observed in normal rats, fructose-fed rats, and SHROB rats (Rösen et al., 1997; Velliquette and Ernsberger, 2003). This acute effect is apparently related to a $\alpha_{2^{-}}$ adrenergic activity, whereas the beneficial action of the chronic treatments is the consequence of the activation of $I_{1}$ receptors.

Since $I_{1}$ receptor agonists not only lower blood pressure but improve glucose intolerance, insulin resistance, and hyperlipidemia, it made sense to think of the metabolic syndrome as a possible new application for such compounds. As can be seen above, at least in the case of glucose intolerance, it appears that the action on $\alpha_{2}$-adrenergic receptors of $\mathrm{I}_{1} / \alpha_{2}$-adrenoceptor mixed agonists is likely to limit their favorable effects. Making drugs highly selective for $I_{1}$ receptors would be an interesting challenge to test the hypothesis according to which such selectivity would improve the therapeutic efficacy in metabolic syndrome but would also have a better tolerance profile. In a pharmacochemistry study, Gasparik et al. (2015) designed and synthesized a series of aminopyrrolines that were highly selective for $\mathrm{I}_{1}$ receptors to the extent that some of them lacked any detectable affinity and activity at $\alpha_{2}$-adrenergic receptors. A lead compound LNP599 was selected on the basis of these pharmacological properties but also for its favorable lipophilicity to allow passage through the blood-brain barrier (Gasparik et al., 2015). In an experimental model of metabolic syndrome in rats (i.e., rats with spontaneously hypertensive heart failure), this compound had favorable effects on blood pressure because of its sympathoinhibitory activity as well as favorable effects on insulin resistance, glucose tolerance, and lipid profile, and it also stabilized body weight. The metabolic effects of LNP599 were associated with the stimulation of adiponectin secretion (Fellmann et al., 2013a). A specific study showed that in addition to sympathetic inhibition and stimulation of adiponectin secretion by adipocytes, the $\mathrm{I}_{1}$-selective agent LNP599 improves insulin sensitivity in the liver (Weiss et al., 2015).

In conclusion of this section on the pharmacology of $\mathrm{I}_{1}$ receptors and their ligands, the recent development of very selective pharmacological agents suggests the possibility of developing new centrally acting drugs with fewer side effects compared with the historical reference drugs such as clonidine, moxonidine, and rilmenidine (see section II). A summary of the pharmacological effects mediated via $\mathrm{I}_{1}$ receptors is provided in Table 1. It is also pharmacologically legitimate to think about new indications of such new drugs: the metabolic syndrome already appears as an interesting target.

\section{Imidazoline Subtype 2 Receptors}

\section{A. Definition, Distribution, and Composition}

As discussed above, $\mathrm{I}_{2}$ imidazoline receptors are defined as the nonadrenergic binding sites that bind $\left[{ }^{3} \mathrm{H}\right]$-idazoxan with high affinity and bind $\left[{ }^{3} \mathrm{H}\right]-p$ aminoclonidine and $\left[{ }^{3} \mathrm{H}\right]$-clonidine at substantially lower affinity (Regunathan and Reis, 1996). Largely identified by ligand binding, $\mathrm{I}_{2}$ receptors are found in many organs, tissues, and cell types, including but not limited to the brain, kidney, liver, colon, placenta, urethra, prostate, adrenal medulla, carotid bodies, astrocytes, glial cells, platelets, pancreatic cells, and vascular smooth muscle cells (Regunathan and Reis, 1996).

Unlike $\mathrm{I}_{1}$ receptors, which are considered a homogenous entity, the $\mathrm{I}_{2}$ receptors are highly heterogenous. Largely through binding studies, it was initially proposed to differentiate $\mathrm{I}_{2}$ receptors into $\mathrm{I}_{2 \mathrm{~A}}$ and $\mathrm{I}_{2 \mathrm{~B}}$ subtypes based on their binding affinity to the drug amiloride (Diamant et al., 1992). This seemed consistent with drug competition curve studies, which typically showed biphasic competitor binding curves for a number of $\mathrm{I}_{2}$ ligands (Miralles et al., 1993). However, functional evidence supporting such a classification is lacking. Studies using a polyclonal antiserum against idazoxan-binding proteins found four different protein bands, which slightly differed between rat and rabbit brain tissues (rat brains: approximately $30,45,66$, and $85 \mathrm{kDa}$; rabbit brains: approximately $30,57,66$, and 85 $\mathrm{kDa}$ (Olmos et al., 1999a). Repeated treatment with $\mathrm{I}_{2}$ receptor ligands such as BU224 and tracizoline, also known as LSL61122 (2-styryl-4,5-dihydro-l $H$-imidazole) and valldemossine, significantly reduced the 30-, 45-, and $66-\mathrm{kDa}$ protein levels in the mouse brain, whereas treatment with idazoxan, the purported $\mathrm{I}_{2}$ receptor antagonist, increased these levels (Keller and GarcíaSevilla, 2015), demonstrating the biochemical correlates of $\mathrm{I}_{2}$ receptor ligands and these proteins. Using the prototypical $\mathrm{I}_{2}$ receptor ligand 2-BFI to generate an affinity column, other studies successfully isolated and sequenced one of the proteins, which was identified as the brain creatine kinase (Kimura et al., 2009). These investigators demonstrated that brain creatine kinase binds $\left[{ }^{3} \mathrm{H}\right] 2-\mathrm{BFI}$, and this binding was attenuated by BU224 or the irreversible $\mathrm{I}_{2}$ receptor ligand BU99006. Thus, the identity of the approximately 45$\mathrm{kDa}$ protein band as reported earlier (Olmos et al., 1999a) has likely been solved. However, the identities of other protein bands remain a mystery. Furthermore, the functional correlates between various reported pharmacological effects of $\mathrm{I}_{2}$ receptor ligands and brain creatine kinase remains elusive.

At the subcellular level, $\mathrm{I}_{2}$ receptors are primarily located at the outer membrane of mitochondria and are 


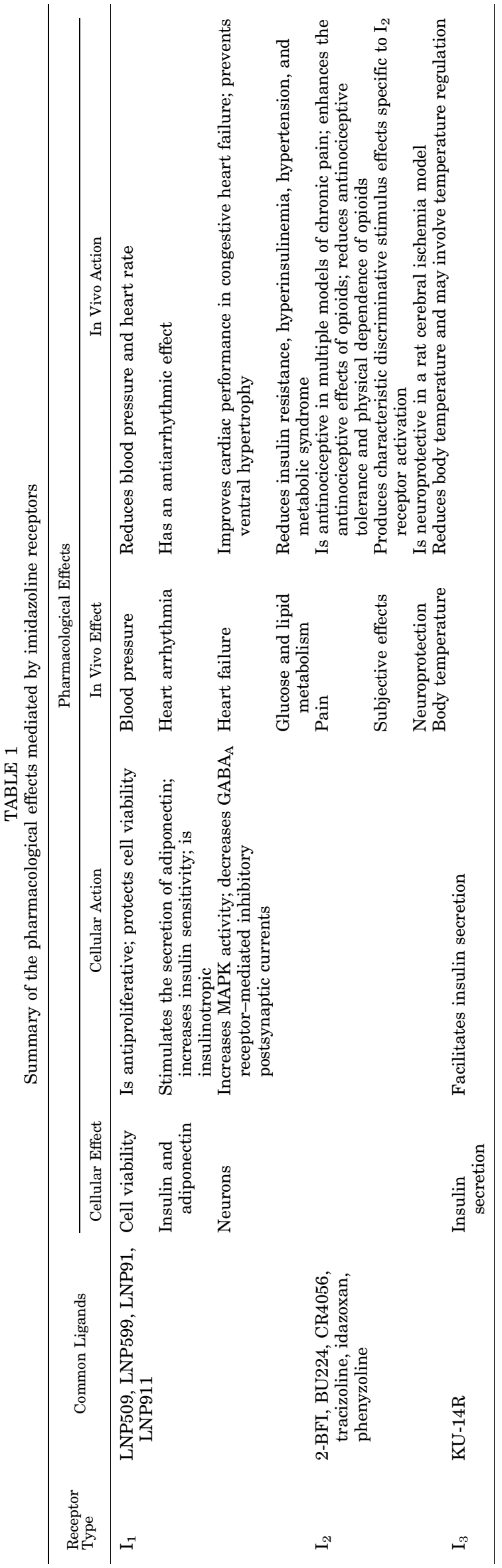

thought to be novel allosteric binding sites of $\mathrm{MAO}_{\mathrm{A}}$ and MAOB (Tesson et al., 1991, 1995; Parini et al., 1996). However, MAO likely only accounts for a portion of the total $\mathrm{I}_{2}$ receptor binding, as substantial binding remains in MAO knockout mice (Remaury et al., 2000; Anderson et al., 2006b). Consistent with this observation, brain creatine kinase is apparently unrelated to MAO (Kimura et al., 2009).

In summary, the current consensus is that the $\mathrm{I}_{2}$ receptors represent a group of heterogenous proteins that $\mathrm{I}_{2}$ receptor ligands such as idazoxan and 2-BFI recognize; some of these binding sites are related to MAO and others are not. Therefore, it is important to note that referring to " $\mathrm{I}_{2}$ receptors" in the literature does not refer to a specified molecular identity. Rather, it refers to several different and potentially biologically diverse protein molecules. This clarification proves to be useful in interpreting many recent functional results.

\section{B. Synthetic Imidazoline Subtype 2 Receptor Ligands}

Because idazoxan was initially used to characterize $\mathrm{I}_{2}$ receptors but it also binds to adrenoceptors, medicinal chemistry efforts have been actively developing selective $\mathrm{I}_{2}$ receptor ligands with low $\mathrm{I}_{1}$ and $\alpha_{2}$-adrenogic receptor binding activities. The chemical structures of some commonly used $\mathrm{I}_{2}$ receptor ligands are given in Fig. 4. A large library of selective $\mathrm{I}_{2}$ receptor ligands have been developed over the years and the effort continues. For example, a recent study describes a new family of (2-imidazolin-4-yl) phosphonates that have high affinity for $\mathrm{I}_{2}$ receptors (Abás et al., 2017). Among those compounds, several such as 2-BFI, BU224, phenyzoline, and CR4056 have been commonly used in previous studies to explore $\mathrm{I}_{2}$ receptor pharmacology and have become valuable research tools. Among these synthetic ligands, two are worthy of discussion because both have moved from preclinical research to human studies.

${ }^{11} \mathrm{C}-\mathrm{BU} 99008$ is a new radiolabeled $\mathrm{I}_{2}$ receptor ligand that has been used in positron emission tomography (PET) studies with human volunteers to demonstrate the distribution of these receptors in the brain (Tyacke et al., 2018). In the future, this PET ligand may make great inroads in expanding our understanding of $\mathrm{I}_{2}$ receptors in neurodegenerative disorders. In fact, ${ }^{11} \mathrm{C}$-BU99008 was developed with the knowledge that the $\mathrm{I}_{2}$ receptor density changes in several psychiatric conditions particularly where there is marked gliosis. Therefore, this PET ligand could not only be used to confirm and monitor neurodegenerative disease, but it would also detect glioblastomas. The authors of this study had previously established that ${ }^{11} \mathrm{C}-\mathrm{BU} 99008$ has low affinity for $\mathrm{MAO}_{\mathrm{B}}$ and high affinity and selectivity for $\mathrm{I}_{2}$ receptors (Parker et al., 2014). Nonetheless, in their current study, volunteers were cotreated with the irreversible MAO inhibitor isocarboxazid, which showed that the signal in the human brain from ${ }^{11} \mathrm{C}-\mathrm{BU} 99008$ was unaffected by MAO inhibition. In contrast, pretreatment 
of volunteers with an oral dose of idazoxan (20 and 80 $\mathrm{mg}$ ) showed marked attenuation of the ${ }^{11} \mathrm{C}-\mathrm{BU} 99008$ signal across all brain regions (Fig. 5). Although this initial study represents PET scans from a small number of volunteers, the clarity of the ${ }^{11} \mathrm{C}-\mathrm{BU} 99008$ signal in the human brain is remarkable, with structures such as the striatum, thalamus, amygdala, and other key areas clearly visible (Fig. 5). To quote the authors' conclusions, "This new clinical imaging tool has paved the way for more in-depth clinical investigations into the role of $\mathrm{I}_{2}$ binding sites in disease states and in the development of potential therapies" (Tyacke et al., 2018, p. 1602).

Another significant advancement in the field is the development of CR4056 (Fig. 4) which has shown positive results in one phase II clinical trial for the treatment of chronic pain related to knee osteoarthritis (Rovati et al., 2017) (see below for further details).

\section{Neuropharmacology of Imidazoline Subtype 2 Receptor Ligands}

In recent years, an increasing number of studies have used selective $\mathrm{I}_{2}$ receptor ligands in various functional assays and have identified several increasingly promising therapeutic uses of $\mathrm{I}_{2}$ receptor agonists. In addition, the study of these compounds also provides novel insights into understanding the nature of $\mathrm{I}_{2}$ receptors. Interestingly, although $\mathrm{I}_{2}$ receptors have a wide distribution, most studies related to $\mathrm{I}_{2}$ receptor functions focus on the CNS. This probably is not surprising given the fact that earlier correlational studies using human tissue consistently report that the expression of $\mathrm{I}_{2}$ receptors was significantly altered in several neuropsychiatric diseases (García-Sevilla et al., 1999). This section will review four well characterized in vivo effects of $\mathrm{I}_{2}$ receptor ligands: analgesic, discriminative stimulus, neuroprotective, and hypothermic effects. These pharmacological effects are also summarized in Table 1.

1. Pain. One of the best studied pharmacological effects of $\mathrm{I}_{2}$ receptor ligands is their potential analgesic effects, which have been demonstrated with various $\mathrm{I}_{2}$ receptor ligands across multiple preclinical pain models.

The overall findings for $\mathrm{I}_{2}$ receptor agonists support the notion that these compounds are not very effective for acute nociception in thermal stimulus-induced pain models. Earlier studies found that $\mathrm{I}_{2}$ receptor ligands, including 2-BFI, tracizoline, phenyzoline, and LSL60101, do not produce significant antinociception in rodent models of acute nociception such as radiant tail flick and hot plate assays (Boronat et al., 1998; Sánchez-Blázquez et al., 2000; Gentili et al., 2006). More recent studies from Li's group are consistent with these findings. 2-BFI and phenyzoline only produced mild antinociception, whereas other selective $\mathrm{I}_{2}$ receptor ligands such as BU224 and S22687 (5-[2methyl phenoxy methyl]-1,3-oxazolin-2-yl) amine) had no effect in a warm water tail flick assay (Thorn et al., 2011; Sampson et al., 2012).

$\mathrm{I}_{2}$ receptor agonists are generally efficacious for chemical stimulus-induced pain. For example, in one study, 2BFI, BU224, and morphine were found equally effective in decreasing the writhing response in a writhing test (Li et al., 2011). In another study employing intraplantar injection of capsaicin-induced mechanical allodynia, CR4056, which as mentioned above is a structurally novel $\mathrm{I}_{2}$ receptor agonist, completely reversed capsaicininduced neurogenic/inflammatory allodynia, and the effect was dose-dependently prevented by idazoxan (Ferrari et al., 2011). In the formalin test (a widely used chemical stimulation-induced persistent pain model), the rodents demonstrate nocifensive behaviors that typically include two phases: an early phase I that is primarily neurogenic and a later phase II that is primarily inflammatory (Hunskaar and Hole, 1987). 2-BFI, BU224, and CR4056 all dose-dependently reduced the flinching response during phase II (Thorn et al., 2016b).

Overall, several studies have consistently shown that $\mathrm{I}_{2}$ receptor agonists are effective in various animal models of chronic pain. Thus, the selective $\mathrm{I}_{2}$ receptor agonists 2-BFI, BU224, and tracizoline all significantly reduced

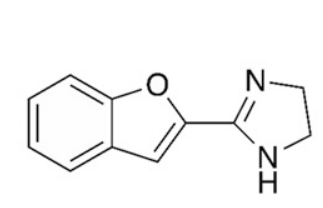

2-BFI

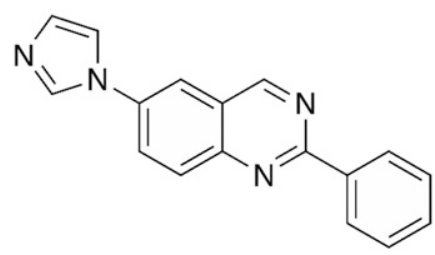

CR4056

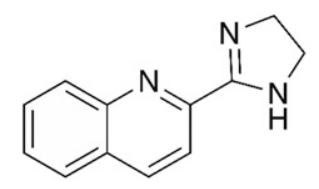

BU224

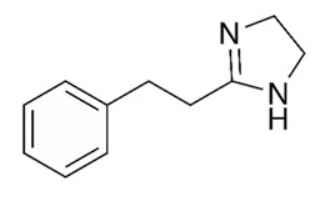

Phenyzoline

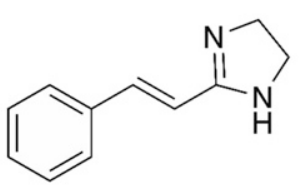

Tracizoline<smiles>c1ccc2c(c1)OCC(C1=NCCN1)O2</smiles>

Idazoxan

Fig. 4. Chemical structures of $\mathrm{I}_{2}$ receptor ligands 2-BFI, BU224, tracizoline, CR4056, phenyzoline, and idazoxan. 


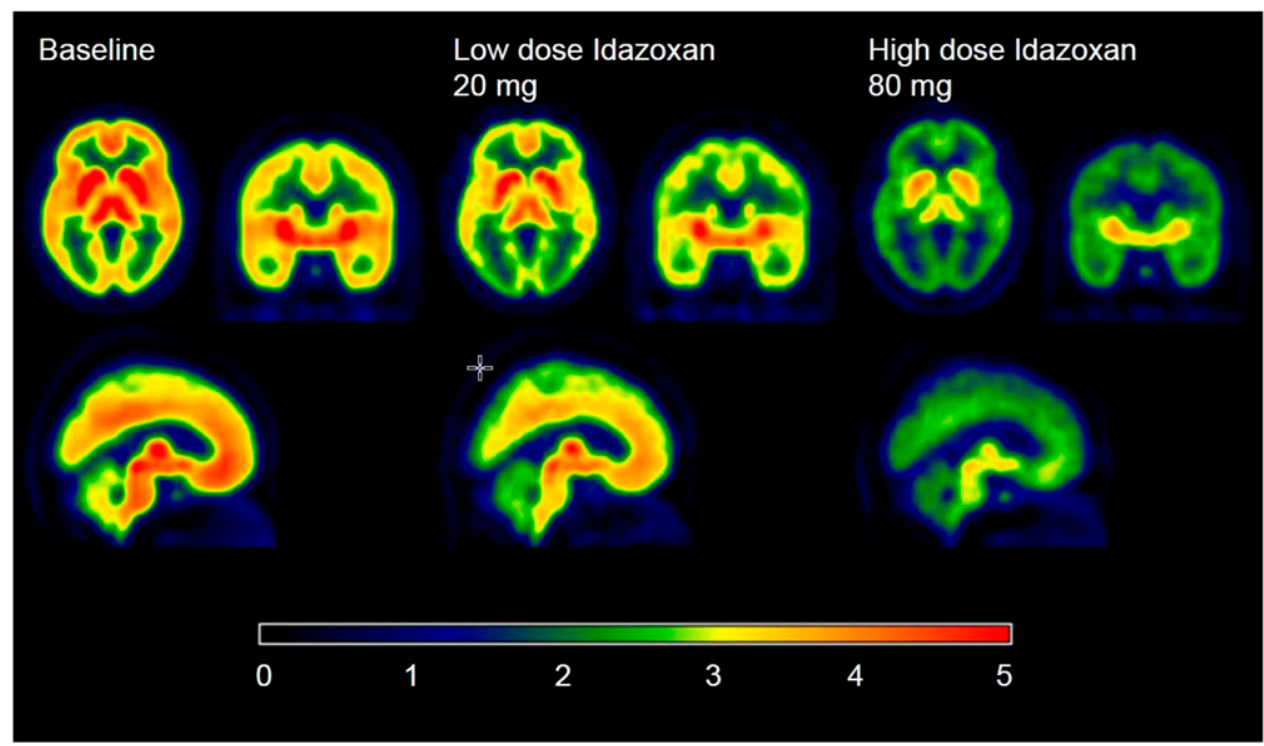

Fig. 5. PET imaging of $I_{2}$ receptors in healthy volunteers treated with the radioligand ${ }^{11} \mathrm{C}-\mathrm{BU} 99008$. Data adapted from Tyacke et al. (2018) with permission.

the mechanical allodynia and thermal hyperalgesia in a complete Freund's adjuvant (CFA)-induced inflammatory pain model (Li et al., 2014). 2-BFI and phenyzoline also both attenuated mechanical allodynia in a rat peripheral neuropathic pain model [chronic constriction injury (CCI)] (Li et al., 2014; Thorn et al., 2017). The antiallodynic effects of 2-BFI and phenyzoline were attenuated by idazoxan, confirming an $\mathrm{I}_{2}$ receptormediated mechanism ( $\mathrm{Li}$ et al., 2014; Thorn et al., 2015; Siemian et al., 2016a). In a series of studies, CR4056 demonstrated a robust antihyperalgesic effect in several different rat models of chronic pain. CR4056 reduced mechanical allodynia in CFA-treated rats (Ferrari et al., 2011), attenuated mechanical hyperalgesia in diabetes-induced neuropathic pain (Ferrari et al., 2011), and reduced neuropathic pain induced by chronic treatment with the chemotherapeutic agent bortezomib (Meregalli et al., 2012). Interestingly, CR4056 was also effective in a rat model of fibromyalgia (Ferrari et al., 2011). When acidic saline (pH 4, $150 \mu \mathrm{l}$ ) is injected into the right gastrocnemius muscle, rats demonstrate a persistent mechanical allodynia condition, which is thought to mimic human chronic pain syndromes such as fibromyalgia (Nielsen et al., 2004). CR4056 significantly reversed acidic saline-induced mechanical allodynia (Ferrari et al., 2011). In another study, CR4056 was fully effective in reversing mechanical allodynia in a postoperative pain model, and this effect was blocked by idazoxan (Lanza et al., 2014). In the same study, no sex difference was found for CR4056induced antinociception (Lanza et al., 2014). Together, these studies convincingly show that $I_{2}$ receptor agonists are able to attenuate various chronic painful conditions and may represent a novel class of analgesics with a broad spectrum of analgesic activity. These findings are significant because many chronic pain conditions respond poorly to existing pharmacotherapies; as such, $\mathrm{I}_{2}$ receptor agonists could provide urgently needed treatments for certain complex chronic pain conditions. Indeed, a phase II multisite, randomized placebo-controlled clinical trial on CR4056 in a group of 213 patients with knee osteoarthritis was recently completed (Rovati et al., 2017). In this study, CR4056 at oral doses of 100 or $200 \mathrm{mg}$ twice daily produced significant analgesic activity in a short 2-week study. Not only were the doses well tolerated and no serious adverse events were noted, but interestingly the analgesic effect was more prominent in patients with obesity (Rovati et al., 2017). This is very exciting progress, and larger long-term trials are planned based on these results. In addition, the potential clinical indications have been expanded to other painful conditions including an ongoing phase II clinical trial studying the analgesic effect of CR4056 in patients with postoperative dental pain. If CR4056 is eventually approved, this would be an analgesic with a completely novel mechanism of action and the first-in-class drug to treat chronic pain based on $\mathrm{I}_{2}$ receptor pharmacology.

The existing evidence supports that $\mathrm{I}_{2}$ receptor agonists are most effective for the management of chronic pain and persistent pain. Because chronic pain is long-lasting and pharmacotherapies of chronic pain require repeated drug use, the possibility of the development of analgesic tolerance has to be carefully considered. The available data suggest that such a possibility is quite low for $\mathrm{I}_{2}$ receptor agonists. For example, daily treatment with 2-BFI or CR4056 at the dose that produced the maximal antihyperalgesic effect for at least 1 week failed to produce observable tolerance in CFA-treated rats (Li et al., 2014). In another study using the chemotherapeutic agent-induced neuropathic pain model, daily treatment with a CR4056 dose 
$(6 \mathrm{mg} / \mathrm{kg})$ that completely prevented mechanical allodynia for 3 weeks did not produce observable antinociceptive tolerance (Meregalli et al., 2012). Using a much more aggressive treatment regimen (twice-daily treatment for 19 days), phenyzoline at the dose that produced near maximal antinociceptive effect only produced a slight antinociceptive tolerance in CFA-treated and CCI rats (Thorn et al., 2017). In contrast, oxycodone produced dramatic antinociceptive tolerance under similar treatment conditions (Thorn et al., 2017). In summary, this accumulating evidence suggests that the possibility for developing tolerance to the antinociceptive effects for $\mathrm{I}_{2}$ receptor agonists is relatively low as long as the doses used are close to therapeutically relevant doses.

Given the complexity and diversity of painful conditions, it is unrealistic to expect one analgesic drug to treat all pain. Combination therapy could offer a more effective approach for pain control. This strategy may be able to achieve better analgesia and produce fewer adverse effects due to the smaller doses needed. Several studies have examined the antinociceptive interactions between $\mathrm{I}_{2}$ receptor ligands and other analgesic agents. One study reported that 2-BFI shifted the opioid antinociceptive dose-effect curves leftward and markedly enhanced the antinociceptive effects of morphine and tramadol (Thorn et al., 2011). Although $\mathrm{I}_{2}$ receptor agonists are not effective for acute pain, combining them with opioids to treat acute pain could substantially reduce the opioid dose needed, which is obviously clinically beneficial. Similar results were found in a writhing test in which the combination of morphine and 2-BFI or BU224 produced synergistic antinociception ( $\mathrm{Li}$ et al., 2011). The interaction between 2-BFI and opioids is partially determined by the efficacy of the opioids at the $\mu$-opioid receptors. For example, although both the high-efficacy opioid fentanyl and the moderate-efficacy opioids morphine and oxycodone produced additive antinociceptive interactions with 2-BFI in CFA-treated rats (Li et al., 2014; Thorn et al., 2015), lower-efficacy opioids such as buprenorphine and NAQ (17-cyclopropylmethyl-3,14 $\beta$-dihydroxy- $4,5 \alpha$-epoxy- $6 \alpha$ [( 3 '-isoquinolyl) acetamido] morphine) produced synergistic interactions with 2-BFI in the same pain model (Siemian et al., 2016b). The interaction also seems to depend on which $\mathrm{I}_{2}$ receptor agonist is used. For example, phenyzoline produced synergistic antinociceptive interactions with oxycodone in CFA-treated rats (Thorn et al., 2015), whereas CR4056 produced synergistic interactions with morphine in models of capsaicin-induced neurogenic pain (Ferrari et al., 2011) and postoperative pain (Lanza et al., 2014). Together, these studies strongly suggest that $I_{2}$ receptor agonists and opioids produce overall preferable antinociceptive interactions under several different painful conditions and may be a viable combination therapy strategy to treat pain. Several factors such as the drugs used (both $\mathrm{I}_{2}$ receptor ligands and opioids) and the pain conditions are important determinants of drug-drug interactions.

Besides the favorable antinociceptive interactions, increasing evidence also suggests that $I_{2}$ receptor agonists can actually reduce some adverse effects related to prolonged opioid use. Chronic opioid use often leads to significant adverse effects such as constipation, dependence, and increased propensity to addiction. Two studies examined the concern of opioid-induced physical dependence. In one study, BU224 reduced some naltrexone-precipitated observable withdrawal signs in morphine-dependent rats (Hudson et al., 1999a). In a more systematic study, naltrexone treatment disrupted food-maintained operant responding in rats treated chronically with morphine (Thorn et al., 2016b). 2-BFI treatment reduced the development of tolerance to morphine and attenuated naltrexone-precipitated body weight loss (Thorn et al., 2016b). $\mathrm{I}_{2}$ receptor agonists (2BFI, BU224, and CR4056) also significantly reduced the development of antinociceptive tolerance to repeated morphine treatment (Thorn et al., 2016b). Combined, these results suggest that $I_{2}$ receptor agonists may decrease some adverse effects related to opioid use.

2. Discriminative Stimulus Effects. Drug discrimination is a powerful behavioral pharmacological procedure to study the in vivo mechanism of action of a novel compound. Over half a century's research has convincingly demonstrated that most psychoactive drugs can be distinguished by various species (from mice to humans) and be classified based on their discriminative stimulus effects, and such classifications correlate highly with a specific cellular mechanism of action (Schuster and Johanson, 1988). For example, if a group of rats are trained to recognize a drug with a known mechanism of action as a discriminative stimulus, drugs with the same or similar (overlapping) mechanisms of action typically are able to elicit responding on the same operandum as the training drug (i.e., the test drug "substitutes" for the training drug), consistent with their shared pharmacological mechanism(s) of action.

Several groups have successfully used drug discrimination procedures to study the discriminative stimulus effects of various imidazoline $\mathrm{I}_{2}$ receptor agonists and characterized their pharmacological specificity (Jordan et al., 1996; MacInnes and Handley, 2002; Qiu et al., 2014a,b, 2015). In an early study, rats were trained to discriminate the prototypical $\mathrm{I}_{2}$ receptor agonist 2-BFI (6 mg/kg, i.p.) from saline (Jordan et al., 1996). Rats readily learned the discrimination and substitution studies showed that idazoxan and the $\alpha_{2}$-adrenoceptor antagonist ethoxy idazoxan fully substituted for 2-BFI. The MAO inhibitors moclobemide and pargyline also fully substituted for 2-BFI, suggesting that MAO inhibition plays an essential role in mediating the discriminative stimulus effects of 2-BFI (Jordan et al., 1996). In a follow-up study by the same group, several known $\mathrm{I}_{2}$ receptor ligands were tested: BU224 and BU226 
fully substituted, whereas BU216, LSL60101, and LSL60125 (2-[6-methoxybenzofuran-2-yl] imidazole hydrochloride) partially substituted for 2-BFI (MacInnes and Handley, 2002). The reversible $\mathrm{MAO}_{\mathrm{A}}$ inhibitors, moclobemide and RO41-1049, and the naturally occurring $\mathrm{MAO}_{\mathrm{A}}$ inhibitor $\beta$-carbolines (harmane, norharmane, and harmaline) all exhibited significant and dose-dependent substitution for 2-BFI (MacInnes and Handley, 2002). It is interesting that the reversible MAO-B inhibitors lazabemide and RO16-1649 were not able to produce 2-BFI-like discriminative stimulus effects, suggesting that the activity of $\mathrm{MAO}_{\mathrm{A}}$ but not MAO-B is important in mediating the discriminative stimulus effects of 2-BFI (MacInnes and Handley, 2002). $\mathrm{MAO}_{\mathrm{A}}$ is a limiting factor in monoamine synthesis and is critical in monoaminergic biology. Because $\mathrm{I}_{2}$ receptor agonists have been shown to increase extracellular monoamine levels in the brain (Hudson et al., 1999a), it is therefore reasonable to assume that the modulation of monoaminergic activity may be involved in the discriminative stimulus effects of $\mathrm{I}_{2}$ receptor agonists such as 2-BFI (but see section V.D). Indeed, the monoamine-releasing drugs amphetamine and fenfluramine both dose-dependently substituted for 2-BFI, whereas reuptake inhibitors for norepinephrine (desipramine, reboxetine) and serotonin (clomipramine, citalopram) all only partially substituted for 2-BFI (MacInnes and Handley, 2003). These results suggest that the noradrenergic and serotonergic mechanisms are important in 2-BFI discrimination.

In an attempt to expand the existing knowledge, we trained rats to discriminate several other $I_{2}$ receptor agonists (Qiu et al., 2014a,b, 2015). Rats can readily learn to discriminate $5.6 \mathrm{mg} / \mathrm{kg}$ BU224 (i.p.) from saline. Other $\mathrm{I}_{2}$ receptor ligands, including phenyzoline, tracizoline, CR4056, RS45041 [4-chloro-2-(imidazolin-2-yl) isoindoline hydrochloride], and idazoxan, as well as the $\mathrm{MAO}_{\mathrm{A}}$ inhibitor harmane, all showed full substitution for BU224 (Qiu et al., 2015). Using a newer $\mathrm{I}_{2}$ receptor agonist phenyzoline $(32 \mathrm{mg} / \mathrm{kg})$ as the discriminative cue, RS45041, CR4056, phenyzoline, tracizoline, and harmane all showed full substitution (Qiu et al., 2015). Finally, in rats discriminating CR4056 (10 mg/kg, i.p.) from its vehicle, tracizoline, phenyzoline, RS45041, and idazoxan all fully substituted for CR4056, whereas 2BFI partially substituted and BU224 failed to substitute for CR4056 (Qiu et al., 2014a). Interestingly, harmane failed to produce a significant CR4056-like discriminative stimulus effect under this situation (Qiu et al., 2014a). In summary, these studies strongly suggest that most of the selective $\mathrm{I}_{2}$ receptor ligands studied thus far share similar pharmacological mechanisms of action that presumably are an essential component of $\mathrm{I}_{2}$ receptors, which mediate the characteristic interoceptive cue of the $\mathrm{I}_{2}$ receptor agonists.

Among these findings, substitution tests with idazoxan emerge as a surprising outlier. In nearly all pain studies, idazoxan reliably antagonizes the effects of many $I_{2}$ receptor agonists (Ferrari et al., 2011; Li et al., 2011, 2014; Lanza et al., 2014) and it has long been considered the only known $\mathrm{I}_{2}$ receptor antagonist. However, in all of the drug discrimination studies, idazoxan fully substituted for the training $\mathrm{I}_{2}$ receptor agonists. This is surprising because it essentially shows that idazoxan acts as an agonist in one assay (drug discrimination) but as an antagonist in a different assay (antinociception) when interacting with the same $\mathrm{I}_{2}$ receptor ligands (e.g., 2-BFI, CR4056). The only reasonable explanation for these results seems to be that there exists more than one "I ${ }_{2}$ receptor" and that idazoxan has different pharmacological properties at each of them. This is reasonable, given that $\mathrm{I}_{2}$ receptors have long been known to actually include several proteins (Olmos et al., 1999a). Thus, idazoxan could act like an agonist at one of these $\mathrm{I}_{2}$ receptors (e.g., to produce discriminative stimulus effects) and like an antagonist at another (different) $I_{2}$ receptor (e.g., for antinociception). This notion is sufficient to explain the apparently discordant in vivo results as discussed previously (Qiu et al., 2014a, 2015; Thorn et al., 2016a) and is further supported by two recent findings. First, 2-BFI and BU224 led to seizures in mice at higher doses, an effect that was not attenuated by idazoxan (Min et al., 2013). Second, idazoxan did not block the 2-BFI- and CR4056induced antinociceptive effect in phase II of the formalin test (Thorn et al., 2016b). Thus, it is logical to propose at least two functionally different $\mathrm{I}_{2}$ receptors: one is idazoxan sensitive and another is idazoxan insensitive (Thorn et al., 2016b).

3. Neuroprotection. It was known over 2 decades ago that idazoxan could against protect neuronal damage in a rat model of transient global forebrain ischemia (Gustafson et al., 1989, 1990). This neuroprotection may be partially explained by a small hypothermic effect induced by idazoxan (Craven and Conway, 1997). However, a later study failed to support these findings. In a rat focal cerebral hypoxiaischemia model, idazoxan was found not only to be ineffective but to worsen the brain damage induced by hypoxia (Antier et al., 1999). This discrepancy is difficult to reconcile due to the descriptive nature of the studies.

Recent studies showed more consistent results using a selective $\mathrm{I}_{2}$ receptor ligand 2-BFI. 2-BFI was found to exert significant neuroprotection in a rat model of cerebral ischemia (middle cerebral artery occlusion model) (Han et al., 2009, 2010, 2012). Several cellular and molecular mechanisms appear to be involved in 2BFI-induced neuroprotection. For example, NMDA receptor-mediated currents can be selectively blocked by the endogenous imidazoline receptor ligand agmatine in rat hippocampal neurons; agmatine did not block AMPA or kainate-induced currents (Yang and Reis, 1999). Moreover, imidazoline receptor drugs and 
the candidate IRAS/nischarin (Piletz et al., 1999; Sun et al., 2007) have been associated with antiapoptotic and/or cytoprotective functions, because they were shown to reduce the levels of proapoptotic proteins and to protect cells from cell death induced by noxious stimuli (Choi et al., 2002; Dontenwill et al., 2003; Garau et al., 2013). The NMDA receptor is a glutamate receptor subtype with many available competitive and noncompetitive antagonists. NMDA receptor activation by endogenous glutamate or analogs such as NMDA opens the receptor cation channel, allowing $\mathrm{Ca}^{2+}$ influx and an increase in the intracellular calcium concentration $\left(\mathrm{Ca}^{2+} \mathrm{i}\right)$. Prolonged receptor activation by increasing $\mathrm{Ca}^{2+} \mathrm{i}$ may activate potentially damaging $\mathrm{Ca}^{2+}$-dependent enzymes. Noncompetitive NMDA receptor antagonists such as MK-801 (dizocilpine), ketamine, and phencyclidine block $\mathrm{Ca}^{2+}$ entry by binding to a site within or at the mouth of the cation channel (MacDonald and Nowak, 1990). 2-BFI and idazoxan both produced transient and reversible inhibition of intracellular calcium influx through NMDA receptors (Jiang et al., 2010). Whereas 2-BFI inhibits NMDAstimulated currents, it did not affect AMPA-stimulated currents (Han et al., 2013). Interaction of $\mathrm{I}_{2}$ receptor ligands with NMDA receptors was previously reported (Olmos et al., 1996, 1999b), and these results support modulation of NMDA receptor activity by $\mathrm{I}_{2}$ receptor ligands. These mechanisms were used to explain the neuroprotective effects of 2-BFI and idazoxan in a glutamate toxicity test using cortical neurons in vitro (Jiang et al., 2010; Han et al., 2013). In the cerebral ischemia model, 2-BFI reduced terminal deoxynucleotidyl transferase-mediated digoxigenin-deoxyuridine nick-end labeling-positive cells, preserved the integrity of subcellular structures, and significantly increased the Bcl-2 expression level, further confirming neuroprotection at the cellular and molecular levels (Han et al., 2010). To further extend the molecular observations from 2-BFI to other $\mathrm{I}_{2}$ receptor ligands, a recent study examined the effects of acute and chronic treatment with four different $\mathrm{I}_{2}$ receptor ligands (2-BFI, tracizoline, BU224, and LSL60101) on a battery of molecules within the canonical apoptotic pathways (Garau et al., 2013).

In many in vitro and in vivo models, NMDA receptor blockade may provide a molecular basis for the neuroprotective actions of imidazoline receptor ligands. However, imidazoline receptor ligands also interact (in the micromolar range) with the MAO enzymes (e.g., see Parini et al., 1996; Ozaita et al., 1997; Ferrari et al., 2011) and various cation channels [reviewed in Olmos et al. (1999a)]. These compounds also block ATP-sensitive $\mathrm{K}^{+}$channels in pancreatic $\beta$-cells and rat insulinoma cells, which leads to the stimulation of insulin release (Jonas et al., 1992; Olmos et al., 1994; Berdeu et al., 1997; Proks and Ashcroft, 1997). Imidazoline receptor ligands can also inhibit the acetylcholine-induced secretion of catecholamines in adrenal chromaffin cells by blocking nicotinic acetylcholine receptors (Musgrave et al., 1995). $\mathrm{I}_{2}$ receptor ligands also interact with the 5$\mathrm{HT}_{3}$ receptor channel in N1E-115 cells, inhibiting the veratridine-induced influx of guanidinium into these cells (Molderings et al., 1996). Moreover, in vitro interactions with red cell Gardos channels (Coupry et al., 1996) and rat brain NMDA receptors (Olmos et al., 1996) have also been reported for these compounds [see Olmos et al. (1999b)].

Although effects of $\mathrm{I}_{2}$ receptor ligands on the variety of potential mechanisms as discussed above may be useful to interpret the neuroprotective effects of certain $\mathrm{I}_{2}$ receptor ligands, 2-BFI was the only selective $\mathrm{I}_{2}$ receptor ligand that was ever tested in in vivo functional studies that involve a well characterized animal model and generalization to other $\mathrm{I}_{2}$ receptor ligands has not been attempted. This is problematic because marked inconsistencies exist in the effects of the $\mathrm{I}_{2}$ receptor ligands on biochemical events, and it is essentially impossible to link any of those changes to a specific $\mathrm{I}_{2}$ receptor component. In addition, the effects are also only correlational, and it is unknown whether the molecules are actually on the $\mathrm{I}_{2}$ receptor signaling pathway.

4. Body Temperature. Imidazoline $\mathrm{I}_{2}$ receptor ligands can reduce body temperature, and this effect is mediated by $\mathrm{I}_{2}$ receptors as shown by pharmacological antagonism studies (Thorn et al., 2012). Indeed, the hypothermic effect was significantly reversed by the prototypical $\mathrm{I}_{2}$ receptor antagonist idazoxan, but not by the $\mathrm{I}_{1}$ receptor antagonist efaroxan or the $\alpha_{2}$-adrenoceptor antagonist yohimbine (Thorn et al., 2012). In addition, this is a general effect that is shared by all $\mathrm{I}_{2}$ receptor ligands that have been studied in rats and is highly dose and time dependent. This simple and straightforward in vivo assay (hypothermia) is increasingly used as a preliminary study of newly synthesized $\mathrm{I}_{2}$ receptor ligands and is particularly useful when combined with specific receptor antagonists (Abás et al., 2017). As discussed above, because body temperature reduction can produce significant neuroprotection under certain conditions such as in cerebral ischemia (Craven and Conway, 1997), the observed $\mathrm{I}_{2}$ receptor agonistinduced neuroprotection could be partially attributable to drug-induced hypothermia (Craven and Conway, 1997).

\section{Pharmacological and Neurobiological Mechanisms}

Although the potential mechanisms discussed above on the neuroprotective actions of $\mathrm{I}_{2}$ receptor agonists are intriguing and helpful, evidence increasingly suggests that these mechanisms are unlikely to account for the in vivo pharmacological effects of $I_{2}$ receptor agonists in pain and drug discrimination. For example, unlike 2-BFI, LSL60101 treatment did not change the apoptotic biomarkers (Garau et al., 2013), but it enhanced 
morphine antinociception similar to 2-BFI and substituted for 2-BFI in rats trained to discriminate 2-BFI (SánchezBlázquez et al., 2000; MacInnes and Handley, 2002). Moreover, although tracizoline showed a different pattern in manipulating the canonical apoptotic pathways (Garau et al., 2013) than 2-BFI, the two compounds showed strikingly similar behavioral effects: they both produced antihyperalgesia, reduced body temperature, and demonstrated symmetrical substitution in drug discrimination (Thorn et al., 2012; Li et al., 2014; Qiu et al., 2015).

Existing evidence strongly suggests that $I_{2}$ receptor agonists are able to modulate the monoaminergic system possibly via inhibition of $\mathrm{MAO}_{\mathrm{A}}$ activity. Several $\mathrm{I}_{2}$ receptor agonists such as 2-BFI and BU224 and the novel $\mathrm{I}_{2}$ receptor agonist CR4056 have been shown to inhibit human recombinant $\mathrm{MAO}_{\mathrm{A}}$ activity in a concentration-dependent manner, and in vivo these drugs caused marked increases in norepinephrine and serotonin content in the rat cerebral cortex and lumbar spinal cord (Ferrari et al., 2011; see also Jones et al., 2007). Li's group has examined the involvement of the monoaminergic system in 2-BFI- and CR4056-induced antinociception in two chronic pain rat models: CFA-induced inflammatory pain and CCI-induced neuropathic pain (Siemian et al., 2018). 2-BFI induced dose-dependent antiallodynia in CCI rats; pretreatment with the selective serotonin reuptake inhibitor fluoxetine or the norepinephrine reuptake inhibitor desipramine dosedependently and significantly enhanced the effects of 2BFI and shifted the 2-BFI dose-effect curve leftward (Siemian et al., 2018). The dopamine reuptake inhibitor GBR12909 failed to alter the antiallodynic effect of 2-BFI under the same condition. To further explore the involvement of serotonin and norepinephrine in 2-BFI-induced antinociception, we used a combination of parachlorophenylalanine and fenfluramine to deplete endogenous serotonin and used DSP-4 [N-(2-chloroethyl)$N$-ethyl-2-bromobenzylamine], a neurotoxin selective for noradrenergic neurons, to deplete norepinephrine. This treatment protocol dramatically attenuated the antinociceptive effect of 2-BFI (Siemian et al., 2018). These results clearly demonstrate that serotonin and norepinephrine, but not dopamine, are important in 2BFI-induced antinociception. Because both serotonin and norepinephrine include multiple subtype receptors, the role of some receptors that reportedly are involved in pain processing was studied in $\mathrm{I}_{2}$ receptor agonist-induced antinociception. Thus, for both 2-BFIand CR4056-induced antinociception in CCI rats, the selective $5-\mathrm{HT}_{1 \mathrm{~A}}$ receptor antagonist WAY100135 [(S)-Ntert-butyl-3-(4-(2-methoxyphenyl)-piperazin-1-yl)-2-phenylpropanamide], the 5- $\mathrm{HT}_{2 \mathrm{~A}}$ receptor antagonist MDL100907 $[(R)-(+)-\alpha-(2,3$-dimethoxyphenyl)-1-[2-(4-fluorophenyl) ethyl]-4-piperinemethanol], and the $\alpha_{1}$-adrenergic receptor antagonist WB4101 [2-(2,6-dimethoxyphenoxyethyl)aminomethyl-1,4-benzodioxane hydrochloride], but not other monoamine receptor antagonists for $5-\mathrm{HT}_{2 \mathrm{C}}$, adrenergic $\alpha_{2}$, dopamine $\mathrm{D}_{1}$, and $\mathrm{D}_{2}$ receptors, dosedependently attenuated the effects of 2-BFI and CR4056. These results suggest that several monoaminergic receptors, including $5-\mathrm{HT}_{1 \mathrm{~A}}$ receptors, $5-\mathrm{HT}_{2 \mathrm{~A}}$ receptors, and adrenergic $\alpha_{1}$ receptors, are critically involved in the $\mathrm{I}_{2}$ receptor agonist-induced antinociceptive effects. These results are consistent with the findings that $\mathrm{I}_{2}$ receptor agonists inhibit $\mathrm{MAO}_{\mathrm{A}}$ activity and increase the central monoamine levels, and they support the central role of the monoaminergic system in mediating $\mathrm{I}_{2}$ receptor agonist-induced antinociception (Siemian et al., 2018).

However, none of the monoaminergic ligands altered 2-BFI-induced hypothermia nor 2-BFI-induced discriminative stimulus effects (Siemian et al., 2018). These results strongly suggest that $I_{2}$ receptor agonists produce antinociceptive effects and discriminative stimulus effects via different pharmacological mechanisms. Results from another study support this notion. Siemian et al. (2017) examined the role of intracellular $\mathrm{Ca}^{2+}$ signaling in 2-BFI-induced antinociception. The L-type $\mathrm{Ca}^{2+}$ channel blockers verapamil and nimodipine, the calmodulin antagonist W-7 [ $N$-(6-aminohexyl)5-chloro-1-naphthalenesulfonamide hydrochloride], and the internal $\mathrm{Ca}^{2+}$ release inhibitor ryanodine all attenuated the antinociceptive effects of 2-BFI. This effect is somewhat specific to 2-BFI, as the same treatment did not alter the antinociceptive effect of oxycodone and acetaminophen. In contrast, in rats reliably discriminating $5.6 \mathrm{mg} / \mathrm{kg} 2$-BFI from saline, verapamil, nimodipine, and W-7 did not alter the discriminative stimulus effects of 2-BFI. Again, these results strongly suggest that $\mathrm{I}_{2}$ receptor agonist-induced antinociception and some other behavioral effects may not be mediated by the same mechanisms. Given the crucial role of internal $\mathrm{Ca}^{2+}$ in mediating neurotransmitter exocytosis, it is not surprising that the inhibition of internal $\mathrm{Ca}^{2+}$ signaling by blocking a key step of the chain reaction disrupts the release of monoamines and the subsequent pharmacological effects of $\mathrm{I}_{2}$ receptor agonists. A schematic figure detailing the proposed mechanistic pathways of $\mathrm{I}_{2}$ receptor agonist-induced antinociception is provided in Fig. 6.

Immunocompetent cells in the CNS, including microglia and astrocytes, have become increasingly recognized as essential players in pain pathophysiology. Glial cells express $\mathrm{I}_{2}$ receptors and several studies have shown that $\mathrm{I}_{2}$ receptor agonists can modulate glial activity. For example, in mice with brain and spinal cord injury induced by experimental autoimmune encephalomyelitis, repeated 2-BFI administration reduced spinal microglial activation, reduced levels of cytokines such as interferon- $\gamma$ and TNF- $\alpha$ in the blood and spinal cord, and improved symptom severity scores (Li et al., 2012; Zhu et al., 2015). In an effort to evaluate whether $\mathrm{I}_{2}$ receptor agonists produce antinociception by directly modulating glial activities, Siemian et al. (2018) 
examined the glial reactivity in the dorsal horn of the spinal cord and the TNF- $\alpha$ levels in CCI rats. CCI injury led to robust microglial and astrocyte activity in the dorsal horn of the spinal cord, which was significantly reduced by repeated 2-BFI treatment at the dose that significantly reduced the mechanical allodynia in the same rats. The TNF- $\alpha$ level in the lumbar spinal cord tissue was significantly higher in CCI rats than sham rats, and this increase was significantly attenuated by 2BFI treatment. To provide direct evidence that 2-BFI acts directly on the glial cells, in vitro mouse cortical astrocyte cultures were used and 2-BFI treatment was found to markedly reduce LPS-stimulated astrocyte activation and reduced TNF- $\alpha$ levels. Together, these results provide direct evidence that 2 -BFI could directly suppress glial activity in CCI rats, which contributes to the observed antinociceptive activities induced by 2-BFI. This potential mechanism of action of $\mathrm{I}_{2}$ receptor agonists is depicted in Fig. 6.

\section{Imidazoline Subtype 3 Receptors}

$\mathrm{I}_{3}$ receptors represent a putative binding site that is different from $I_{1} / I_{2}$ receptors. The nature and the functional characterization of this receptor remains elusive and little progress has been made in the past 2 decades. A brief review of this receptor will be provided here primarily based on the earlier literature (Eglen et al., 1998; Morgan and Chan, 2001).

It has long been recognized that phentolamine, an imidazoline, and other imidazoline compounds administered to human subjects results in an alteration in glycemic control (Cerasi et al., 1969). Later studies established that these compounds may influence the insulin secretory activity of pancreatic $\beta$-cells and that imidazoline binding sites exist on $\beta$-cells (Bousquet et al., 1984; Coupry et al., 1987; Ernsberger et al., 1987). Indeed, using an antiserum that is often used to identify $\mathrm{I}_{2}$ receptors, pancreatic islet tissue was found to contain protein bands that are consistent with $\mathrm{I}_{2}$ receptors (Morgan and Chan, 2001). The existence of $\mathrm{I}_{1}$ receptors is, however, controversial. Using pancreatic $\beta$-cells as the bioassay, some $\mathrm{I}_{2}$ receptor agonists were able to regulate insulin secretion, whereas others did not (Morgan et al., 1999). For example, 2-BFI is an efficient potentiator of glucose-induced insulin secretion in these cells at high concentrations (high micromoles), whereas its typical concentrations for interacting with $\mathrm{I}_{2}$ receptors are much lower (low nanomoles). On the other hand, other $\mathrm{I}_{2}$ receptor ligands (e.g., idazoxan, $\mathrm{RS} 45041-190$ ) do not stimulate insulin release nor do they antagonize the insulin secretory effect of other imidazoline compounds on $\beta$-cells (Chan et al., 1994; Berdeu et al., 1995). These results suggest that 2-BFI and related compounds may not directly modulate $\beta$-cell insulin secretion via $\mathrm{I}_{2}$ receptors.

One proposed model to explain how imidazoline compounds alter insulin secretion states that these compounds bind to a site associated with (or present on) the ATP-sensitive potassium $\left(\mathrm{K}_{\mathrm{ATP}}\right)$ channel, thereby causing a reduction in the rate of potassium efflux. This in turn leads to an increase in the membrane potential (toward a less negative value) and culminates in membrane depolarization with the subsequent gating of voltage-sensitive $\mathrm{Ca}^{2+}$ channels and the triggering of insulin secretion (Morgan and Chan, 2001). This model is based primarily on the findings that imidazoline compounds such as phentolamine can alter the permeability of the $\beta$-cell plasma membrane to both

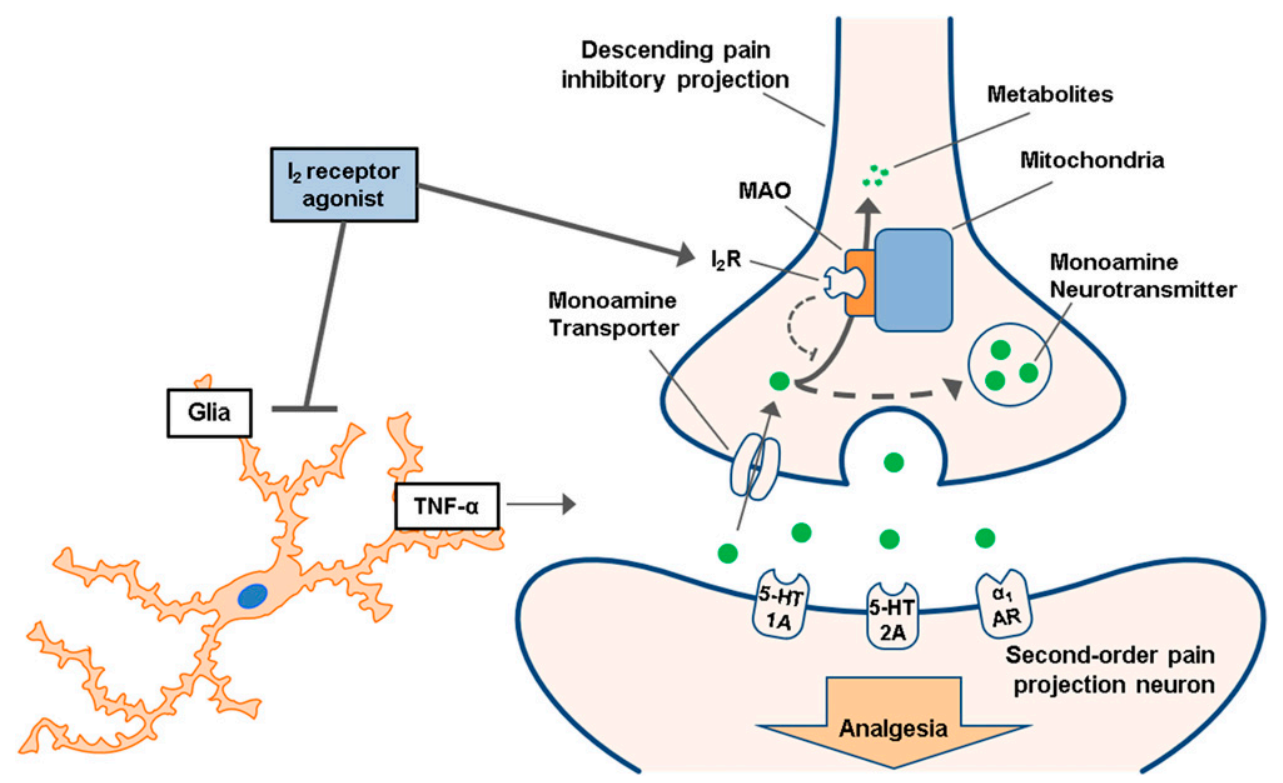

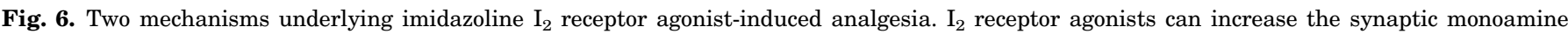

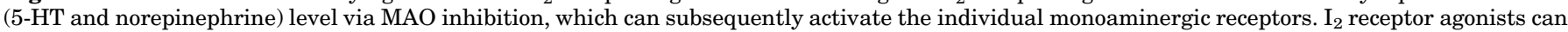

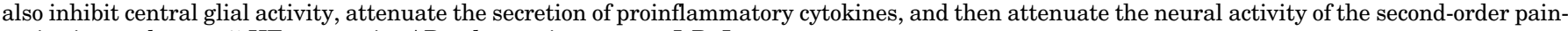
projecting pathways. 5-HT, serotonin; AR, adrenergic receptor; $\mathrm{I}_{2} \mathrm{R}, \mathrm{I}_{2}$ receptor. 
ion flux measurements and by electrophysiological analysis of membrane current flow (Chan et al., 1991; Dunne, 1991). Patch-clamp recording revealed that imidazoline compounds can reduce the rate of potassium efflux through $\mathrm{K}_{\mathrm{ATP}}$ channels. Clearly, this mechanism is drastically different from the conventional recognition of $I_{1}$ and $I_{2}$ imidazoline receptors and has been suggested to involve $\mathrm{I}_{3}$ receptors.

The $\beta$-cell $\mathrm{K}_{\mathrm{ATP}}$ channel is an octomeric complex composed of two subunits: Kir6.2 and sulfonylurea receptor 1 (SUR1). Earlier studies showed that imidazoline compounds retain their activity as $\mathrm{K}_{\mathrm{ATP}}$ channel blockers when truncated Kir6.2 is expressed in the absence of SUR1, suggesting that SUR1 is not required for imidazoline compounds to regulate the ionic conductance of Kir6.2 and that the $\mathrm{I}_{3}$ receptor is located within Kir6.2 itself (Ishida-Takahashi et al., 1996; Proks and Ashcroft, 1997). Subsequent biochemical evidence supports this notion (Monks et al., 1999). Thus, $I_{3}$ receptors represent a binding site that is located on the Kir6.2subunit of $\mathrm{K}_{\mathrm{ATP}}$ channels.

Given that imidazoline compounds are able to modulate insulin secretion via $\mathrm{I}_{3}$ receptors, this receptor may have the potential to be a novel drug target for the development of new antidiabetic drugs. Unfortunately, little progress has been made in this regard. This is due in large part to the fact that how imidazoline compounds stimulate insulin secretion remains to be fully elucidated. Whether the $I_{3}$ receptor is a viable drug target awaits much more detailed mechanistic investigations.

\section{Summary and Conclusions}

Since the last systematic review on the topic of imidazoline receptors and their endogenous ligands (Regunathan and Reis, 1996), the field of imidazoline receptors has seen uneven progress: some quite dramatic and some much less so. The endogenous imidazoline receptor ligands remain an enigma and multiple candidates have been studied and discussed. The past 2 decades also saw a boom in the research on the purported endogenous imidazoline receptor ligand agmatine, including human trials to demonstrate the safety and potential therapeutic benefits for certain pain conditions (Keynan et al., 2010; Gilad and Gilad, 2014). The physiologic and pharmacological effects of agmatine continue to be studied and expanded to new arenas, including learning and memory (Moretti et al., 2014), pain (Li and Zhang, 2011), opioid dependence (Wu et al., 2008), and depression (Freitas et al., 2016). Sufficient preclinical evidence supports promising clinical translations, and the recent call for more translational studies with agmatine is a good reflection of the maturity of this field (Piletz et al., 2013).

Until recently, moxonidine and rilmenidine were considered representative $I_{1}$ receptor agonists that modulate blood pressure. However, both compounds only have marginal $I_{1} / \alpha_{2}$-receptor selectivity (approximately 10 -fold) and their clinical efficacy cannot be solely attributed to $I_{1}$ receptor activity. In this regard, novel compounds such as LNP599 demonstrate extraordinary $I_{1}$ receptor selectivity and exciting therapeutic efficacy in hypertension and the metabolic syndrome (Fellmann et al., 2013a). These new developments may pave the way toward a newer generation of pharmacotherapy against hypertension and related complications.

For many years, one major impediment for $\mathrm{I}_{2}$ receptor research was the lack of well characterized in vivo functionalities that can be related to this receptor with confidence. The most prominent development in this field is the mounting and unequivocal findings that $\mathrm{I}_{2}$ receptor agonists are effective analgesics. This is endorsed by the recent successful phase II clinical trial of CR4056, a selective $\mathrm{I}_{2}$ receptor agonist (Rovati et al., 2017). For the first time, it seems that an $I_{2}$ receptorbased analgesic could become a reality. This would prompt further research to explore other therapeutic potentials of $\mathrm{I}_{2}$ receptor agonists, such as neuroprotection. Using ${ }^{11} \mathrm{C}$-BU99008 as a ligand for imaging $\mathrm{I}_{2}$ receptors in the human brain in real time, researchers can now study these receptors in various neurodegenerative states (Tyacke et al., 2018).

In contrast, there is really not much progress on $\mathrm{I}_{3}$ receptor pharmacology and the research on this receptor remains in its infancy. Further research should remain focused on deciphering the nature of this enigmatic receptor and on developing new and selective $\mathrm{I}_{3}$ receptor ligands to facilitate more extensive pharmacological studies.

In summary, despite several decades of efforts, pharmacologists remain puzzled by the nature of the so-called "imidazoline binding sites." The continued endeavor to decipher the molecular identities of these receptors remains important. However, exciting progress has been made from a different perspective: translational pharmacology. With the new developments in $I_{1}$ and $I_{2}$ receptor pharmacology and their synthetic ligands, now may be the prime time to focus more on imidazoline receptor drug discovery and translating preclinical findings to novel pharmacotherapies to benefit millions of patients suffering from hypertension, metabolic syndrome, chronic pain, and stroke, as imidazoline receptor agonists show the most promising therapeutic potential for these conditions. Looking forward, it is not too radical to predict that imidazoline receptor-based novel therapies are on the horizon.

\section{Authorship Contributions}

Wrote or contributed to the writing of the manuscript: Bousquet, Hudson, García-Sevilla, Li.

\section{References}

Abás S, Erdozain AM, Keller B, Rodríguez-Arévalo S, Callado LF, García-Sevilla JA, and Escolano C (2017) Neuroprotective effects of a structurally new family of high affinity imidazoline $\mathrm{I}_{2}$ receptor ligands. ACS Chem Neurosci 8:737-742.

Abu Ghazaleh H, Lalies MD, Nutt DJ, and Hudson AL (2015a) Harmane: an atypical neurotransmitter? Neurosci Lett 590:1-5. 
Abu Ghazaleh H, Lalies MD, Nutt DJ, and Hudson AL (2015b) The modulatory action of harmane on serotonergic neurotransmission in rat brain. Brain Res 1597:57-64. Abu Ghazaleh H, Tyacke RJ, and Hudson AL (2015c) Borne identity: leading endogenous suspects at imidazoline binding sites. J Neurol Neurosci 6:1-9.

Aceros H, Farah G, Noiseux N, and Mukaddam-Daher S (2014) Moxonidine modulates cytokine signalling and effects on cardiac cell viability. Eur J Pharmacol 740: 168-182.

Aggarwal S, Shavalian B, Kim E, and Rawls SM (2009) Agmatine enhances cannabinoid action in the hot-plate assay of thermal nociception. Pharmacol Biochem Behav 93:426-432.

Aglawe MM, Taksande BG, Kuldhariya SS, Chopde CT, Umekar MJ, and Kotagale NR (2014) Participation of central imidazoline binding sites in antinociceptive effect of ethanol and nicotine in rats. Fundam Clin Pharmacol 28:284-293.

Alahari SK, Lee JW, and Juliano RL (2000) Nischarin, a novel protein that interacts with the integrin alpha5 subunit and inhibits cell migration. J Cell Biol 151: 1141-1154.

Alexander SP, Mathie A, and Peters JA (2011) Guide to receptors and channels (GRAC), 5th edition. Br J Pharmacol 164 (Suppl 1):S1-S324.

Anderson NJ, Seif I, Nutt DJ, Hudson AL, and Robinson ES (2006b) Autoradiographical distribution of imidazoline binding sites in monoamine oxidase A deficient mice. $J$ Neurochem 96:1551-1559.

Anderson NJ, Tyacke RJ, Husbands SM, Nutt DJ, Hudson AL, and Robinson ESJ (2006a) In vitro and ex vivo distribution of $\left[{ }^{3} \mathrm{H}\right]$ harmane, an endogenous $\beta$-carboline, in rat brain. Neuropharmacology 50:269-276.

Antier D, Franconi F, and Sannajust F (1999) Idazoxan does not prevent but worsens focal hypoxic-ischemic brain damage in neonatal Wistar rats. J Neurosci Res 58 690-696.

Antonaccio MJ and Halley J (1977) Clonidine hypotension: lack of effect of bilateral lesions of the nucleus solitary tract in anaesthetized cats. Neuropharmacology 16: 431-433.

Arib O, Rat P, Molimard R, Chait A, Faure P, and de Beaurepaire R (2010) Electrophysiological characterization of harmane-induced activation of mesolimbic dopamine neurons. Eur $J$ Pharmacol 629:47-52.

Aricioglu F, Korcegez E, Bozkurt A, and Ozyalcin S (2003) Effect of agmatine on acute and mononeuropathic pain. Ann N Y Acad Sci 1009:106-115.

Aricioglu-Kartal F, Kayir H, and Tayfun Uzbay I (2003) Effects of harman and harmine on naloxone-precipitated withdrawal syndrome in morphine-dependent rats. Life Sci 73:2363-2371.

Armstrong JM and Boura AL (1973) Effects of clonidine and guanethidine on peripheral sympathetic nerve function in the pithed rat. Br J Pharmacol 47:850-852. Atlas D (1994) Identifying clonidine-displacing substance. Science 266:462-464.

Atlas D and Burstein Y (1984) Isolation and partial purification of a clonidinedisplacing endogenous brain substance. Eur J Biochem 144:287-293.

Atlas D, Diamant S, Fales HM, and Pannell L (1987) The brain's own clonidine: purification and characterization of endogenous clonidine displacing substance from brain. J Cardiovasc Pharmacol 10 (Suppl 12):S122-S127.

Berdeu D, Gross R, Puech R, Loubatières-Mariani MM, and Bertrand G (1995) Evidence for two different imidazoline sites on pancreatic B cells and vascular bed in rat. Eur J Pharmacol 275:91-98.

Berdeu D, Puech R, Ribes G, Loubatières-Mariani MM, and Bertrand G (1997) Antazoline increases insulin secretion and improves glucose tolerance in rats and dogs. Eur J Pharmacol 324:233-239.

Bhalla S, Rapolaviciute V, and Gulati A (2011) Determination of $\alpha(2)$-adrenoceptor and imidazoline receptor involvement in augmentation of morphine and oxycodone analgesia by agmatine and BMS182874. Eur J Pharmacol 651:109-121.

Bogaievsky D, Bogaievsky Y, Tsoucaris-Kupfer D, and Schmitt H (1974) Blockade of the central hypotensive effect of clonidine by alpha-adrenoreceptor and antagonists in rats, rabbits and dogs. Clin Exp Pharmacol Physiol 1:527-534

Bolme P, Corrodi H, Fuxe K, Hökfelt T, Lidbrink P, and Goldstein M (1974) Possible involvement of central adrenaline neurons in vasomotor and respiratory control. Studies with clonidine and its interactions with piperoxane and yohimbine. Eur $J$ Pharmacol 28:89-94.

Boronat MA, Olmos G, and García-Sevilla JA (1998) Attenuation of tolerance to opioid-induced antinociception and protection against morphine-induced decrease of neurofilament proteins by idazoxan and other $\mathrm{I}_{2}$-imidazoline ligands. $\mathrm{Br}$ $J$ Pharmacol 125:175-185.

Boudier HS, de Boer J, Smeets G, Lien EJ, and van Rossum J (1975) Structure activity relationships for central and peripheral alpha adrenergic activities of imidazoline derivatives. Life Sci 17:377-385.

Bousquet P (2001) $\mathrm{I}_{1}$ receptors, cardiovascular function, and metabolism. Am $J$ Hypertens 14:317S-321S

Bousquet P and Feldman J (1987) The blood pressure effects of alpha-adrenoceptor antagonists injected in the medullary site of action of clonidine: the nucleus reticularis lateralis. Life Sci 40:1045-1052.

Bousquet P, Feldman J, Bloch R, and Schwartz J (1980) Medullary cardiovascular effects of tetrodotoxin in anaesthetized cats. Eur J Pharmacol 65:293-296.

Bousquet P, Feldman J, Bloch R, and Schwartz J (1981) The nucleus reticularis lateralis: a region highly sensitive to clonidine. Eur J Pharmacol 69:389-392.

Bousquet P, Feldman J, and Schwartz J (1984) Central cardiovascular effects of alpha adrenergic drugs: differences between catecholamines and imidazolines. $J$ Pharmacol Exp Ther 230:232-236.

Bousquet P and Guertzenstein PG (1973) Localization of the central cardiovascular action of clonidine. $\mathrm{Br} J$ Pharmacol 49:573-579.

Boxwalla M, Matwyshyn G, Puppala BL, Andurkar SV, and Gulati A (2010) Involvement of imidazoline and opioid receptors in the enhancement of clonidineinduced analgesia by sulfisoxazole. Can J Physiol Pharmacol 88:541-552.

Bozdagi O, Wang XB, Martinelli GP, Prell G, Friedrich VL Jr, Huntley GW, and Holstein GR (2011) Imidazoleacetic acid-ribotide induces depression of synaptic responses in hippocampus through activation of imidazoline receptors. J Neurophysiol 105:1266-1275.
Braestrup C, Nielsen M, and Olsen CE (1980) Urinary and brain beta-carboline-3carboxylates as potent inhibitors of brain benzodiazepine receptors. Proc Natl Acad Sci USA 77:2288-2292.

Bralet J and Rochette L (1973) Effect of clonidine on the turnover rate of noradrenaline in peripheral tissues of the rat. Eur $J$ Pharmacol 23:239-244.

Bricca G, Dontenwill M, Molines A, Feldman J, Belcourt A, and Bousquet P (1988) Evidence for the existence of a homogeneous population of imidazoline receptors in the human brainstem. Eur J Pharmacol 150:401-402.

Bricca G, Dontenwill M, Molines A, Feldman J, Belcourt A, and Bousquet P (1989) The imidazoline preferring receptor: binding studies in bovine, rat and human brainstem. Eur J Pharmacol 162:1-9.

Bricca G, Greney H, Zhang J, Dontenwill M, Stutzmann J, Belcourt A, and Bousquet $\mathrm{P}$ (1994) Human brain imidazoline receptors: further characterization with $\left[{ }^{3} \mathrm{H}\right]$ clonidine. Eur J Pharmacol 266:25-33.

Bricca G, Zhang J, Greney H, Dontenwill M, Stutzmann J, Belcourt A, and Bousquet $\mathrm{P}$ (1993) Relevance of the use of $\left[{ }^{3} \mathrm{H}\right]$-clonidine to identify imidazoline receptors in the rabbit brainstem. $\mathrm{Br} J$ Pharmacol 110:1537-1543.

Brown CM, MacKinnon AC, McGrath JC, Spedding M, and Kilpatrick AT (1990) Alpha 2-adrenoceptor subtypes and imidazoline-like binding sites in the rat brain. Br J Pharmacol 99:803-809.

Bruban V, Estato V, Schann S, Ehrhardt J-D, Monassier L, Renard P, Scalbert E, Feldman J, and Bousquet P (2002) Evidence for synergy between alpha(2)-adrenergic and nonadrenergic mechanisms in central blood pressure regulation. Circulation 105:1116-1121.

Bruban V, Feldman J, Greney H, Dontenwill M, Schann S, Jarry C, Payard M, Boutin J, Scalbert E, Pfeiffer B, et al. (2001) Respective contributions of alpha-adrenergic and non-adrenergic mechanisms in the hypotensive effect of imidazoline-like drugs. Br J Pharmacol 133:261-266.

Brunton L, Chabner B, and Knollman B (2011) Goodman and Gilman's the Pharmacological Basis of Therapeutics, McGraw-Hill Education, New York.

Carenzi A, Chiarino D, Napoletano M, Reggiani A, Sala A, and Sala R (1989) New isoxazole derivatives provided with antihypertensive activity. Arzneimittelforschung 39:642-646.

Cavero I, Fénard S, Finch L, Lefevre F, and Roach A (1977) Studies on the rebound hypertension after clonidine withdrawal in conscious hypertensive cats, rats, and dogs [proceedings]. Br J Pharmacol 60:288P-289P

Cavero I and Roach AG (1978) The effects of prazosin on the clonidine induced hypotension and bradycardia in rats and sedation in chicks [proceedings]. $\mathrm{Br}$ I Pharmacol 62:468P-469P.

Cerasi E, Effendic S, and Luft R (1969) Role of adrenergic receptors in glucoseinduced insulin secretion in man. Lancet 2:301-302.

Chan SL, Atlas D, James RF, and Morgan NG (1997) The effect of the putative endogenous imidazoline receptor ligand, clonidine-displacing substance, on insulin secretion from rat and human islets of Langerhans. $B r$ J Pharmacol 120:926-932

Chan SL, Brown CA, Scarpello KE, and Morgan NG (1994) The imidazoline site involved in control of insulin secretion: characteristics that distinguish it from $\mathrm{I}_{1}$ and $\mathrm{I}_{2}$-sites. $\mathrm{Br} J$ Pharmacol 112:1065-1070.

Chan SL and Morgan NG (1998) Sigma receptor ligands and imidazoline secretagogues mediate their insulin secretory effects by activating distinct receptor systems in isolated islets. Eur J Pharmacol 350:267-272.

Chan SL, Stillings MR, and Morgan NG (1991) Mechanisms involved in stimulation of insulin secretion by the hypoglycaemic alpha-adrenergic antagonist, DG-5128. Biochem Biophys Res Commun 176:1545-1551.

Chen MJ, Zhu HE, and Piletz JE (2003) Intracellular effect of imidazoline receptor on alpha(2A)-noradrenergic receptor. Ann N Y Acad Sci 1009:427-438.

Choi DH, Kim DH, Park YG, Chun BG, and Choi SH (2002) Protective effects of rilmenidine and AGN 192403 on oxidative cytotoxicity and mitochondrial inhibitorinduced cytotoxicity in astrocytes. Free Radic Biol Med 33:1321-1333.

Cohn JN, McInnes GT, and Shepherd AM (2011) Direct-acting vasodilators. J Clin Hypertens (Greenwich) 13:690-692.

Cohn JN, Pfeffer MA, Rouleau J, Sharpe N, Swedberg K, Straub M, Wiltse C, and Wright TJ; MOXCON Investigators (2003) Adverse mortality effect of central sympathetic inhibition with sustained-release moxonidine in patients with heart failure (MOXCON). Eur J Heart Fail 5:659-667.

Corboz MR, Rivelli MA, Shah H, Boyce CW, McCormick KD, Chapman RW, and Hunter JC (2013) Role of $\alpha 2$-adrenoceptors in electrical field stimulationinduced contraction of pig nasal mucosa and pharmacologic characterization of a novel $\alpha 2 \mathrm{C}$-adrenoceptor agonist. Am J Rhinol Allergy 27:84-90.

Cottereau MJ, Antebi M, Benyacoub A, Loo H, Roux JM, and Deniker P (1979) [Preliminary assay of clonidine in opiate withdrawal. Results of an open-study (author's transl)]. Nouv Presse Med 8:3267.

Coupry I, Armsby CC, Alper SL, Brugnara C, and Parini A (1996) Clotrimazole and efaroxan inhibit red cell Gardos channel independently of imidazoline $\mathrm{I}_{1}$ and $\mathrm{I}_{2}$ binding sites. Eur J Pharmacol 295:109-112.

Coupry I, Atlas D, Podevin RA, Uzielli I, and Parini A (1990) Imidazolineguanidinium receptive site in renal proximal tubule: asymmetric distribution, regulation by cations and interaction with an endogenous clonidine displacing substance. J Pharmacol Exp Ther 252:293-299.

Coupry I, Podevin RA, Dausse JP, and Parini A (1987) Evidence for imidazoline binding sites in basolateral membranes from rabbit kidney. Biochem Biophys Res Commun 147:1055-1060.

Craven JA and Conway EL (1997) Effects of alpha 2-adrenoceptor antagonists and imidazoline2-receptor ligands on neuronal damage in global ischaemia in the rat. Clin Exp Pharmacol Physiol 24:204-207.

Dahmani S, Rouelle D, Gressens P, and Mantz J (2010) Characterization of the postconditioning effect of dexmedetomidine in mouse organotypic hippocampal slice cultures exposed to oxygen and glucose deprivation. Anesthesiology 112 373-383.

Dardonville C and Rozas I (2004) Imidazoline binding sites and their ligands: an overview of the different chemical structures. Med Res Rev 24:639-661. 
Delbarre B and Schmitt H (1973) A further attempt to characterize sedative receptors activated by clonidine in chickens and mice. Eur J Pharmacol 22:355-359.

De Vos H, Bricca G, De Keyser J, De Backer JP, Bousquet P, and Vauquelin G (1994) Imidazoline receptors, non-adrenergic idazoxan binding sites and alpha 2adrenoceptors in the human central nervous system. Neuroscience 59:589-598.

Dhasmana KM, Fokker WA, and Spilker BA (1972) Peripheral cardiovascular effects, in the pithed rat, of compounds used in the treatment of hypertension. $\mathrm{Br}$ $J$ Pharmacol 46:508-510.

Diamant S, Eldor A, and Atlas D (1987) A low molecular weight brain substance interacts, similarly to clonidine, with alpha 2-adrenoceptors of human platelets. Eur J Pharmacol 144:247-255.

Diamant S, Eldar-Geva T, and Atlas D (1992) Imidazoline binding sites in human placenta: evidence for heterogeneity and a search for physiological function. $\mathrm{Br}$ J Pharmacol 106:101-108

Dontenwill M, Bricca G, Molines A, Bousquet P, and Belcourt A (1988) Production and characterization of anti-clonidine antibodies not cross-reacting with catecholamines. Eur J Pharmacol 149:249-255

Dontenwill M, Piletz JE, Chen M, Baldwin J, Pascal G, Ronde P, Dupuy L, Greney H, Takeda K, and Bousquetd P (2003) IRAS is an anti-apoptotic protein. Ann NY Acad Sci 1009:400-412.

Drew GM, Gower AJ, and Marriott AS (1979) Alpha 2-adrenoceptors mediate clonidine-induced sedation in the rat. Br J Pharmacol 67:133-141.

Dunne MJ (1991) Block of ATP-regulated potassium channels by phentolamine and other alpha-adrenoceptor antagonists. Br J Pharmacol 103:1847-1850.

Dupuy L, Urosevic D, Greney H, Quaglia W, Pigini M, Brasili L, Dontenwill M, and Bousquet $\mathrm{P}$ (2004) $\mathrm{I}_{1}$ imidazoline receptor-mediated effects on apoptotic processes in PC12 cells. Cell Death Differ 11:1049-1052.

Edwards L and Ernsberger P (2003) The I(1)-imidazoline receptor in PC12 pheochromocytoma cells reverses NGF-induced ERK activation and induces MKP-2 phosphatase. Brain Res 980:71-79.

Edwards L, Fishman D, Horowitz P, Bourbon N, Kester M, and Ernsberger P (2001) The $\mathrm{I}_{1}$-imidazoline receptor in $\mathrm{PC} 12$ pheochromocytoma cells activates protein kinases C, extracellular signal-regulated kinase (ERK) and c-Jun N-terminal kinase (JNK). J Neurochem 79:931-940.

Edwards LP, Brown-Bryan TA, McLean L, and Ernsberger P (2012) Pharmacological properties of the central antihypertensive agent, moxonidine. Cardiovasc Ther $\mathbf{3 0}$ 199-208.

Eglen RM, Hudson AL, Kendall DA, Nutt DJ, Morgan NG, Wilson VG, and Dillon MP (1998) 'Seeing through a glass darkly': casting light on imidazoline 'I' sites. Trends Pharmacol Sci 19:381-390.

El-Ayoubi R, Gutkowska J, Regunathan S, and Mukaddam-Daher S (2002) Imidazoline receptors in the heart: characterization, distribution, and regulation. $J$ Cardiovasc Pharmacol 39:875-883.

El-Ayoubi R, Menaouar A, Gutkowska J, and Mukaddam-Daher S (2004) Imidazoline receptors but not alpha 2 -adrenoceptors are regulated in spontaneously hypertensive rat heart by chronic moxonidine treatment. $J$ Pharmacol Exp Ther $\mathbf{3 1 0}$ 446-451.

Ernsberger P, Damon TH, Graff LM, Schäfer SG, and Christen MO (1993) Moxonidine, a centrally acting antihypertensive agent, is a selective ligand for $\mathrm{I}_{1}$-imidazoline sites. J Pharmacol Exp Ther 264:172-182.

Ernsberger P, Giuliano R, Willette RN, and Reis DJ (1990) Role of imidazole receptors in the vasodepressor response to clonidine analogs in the rostral ventrolateral medulla. J Pharmacol Exp Ther 253:408-418.

Ernsberger P and Haxhiu MA (1997) The $\mathrm{I}_{1}$-imidazoline-binding site is a functional receptor mediating vasodepression via the ventral medulla. Am $J$ Physiol 273: R1572-R1579.

Ernsberger P, Koletsky RJ, and Friedman JE (1999) Molecular pathology in the obese spontaneous hypertensive Koletsky rat: a model of syndrome X. Ann NY Acad Sci 892:272-288.

Ernsberger P, Kou YR, and Prabhakar NR (1998) Carotid body $I_{1}$-imidazoline receptors: binding, visualization and modulatory function. Respir Physiol 112:239-251.

Ernsberger P, Meeley MP, Mann JJ, and Reis DJ (1987) Clonidine binds to imidazole binding sites as well as alpha 2-adrenoceptors in the ventrolateral medulla. Eur $J$ Pharmacol 134:1-13.

Ernsberger P, Meeley MP, and Reis DJ (1988) An endogenous substance with clonidine-like properties: selective binding to imidazole sites in the ventrolateral medulla. Brain Res 441:309-318.

Ernsberger P and Shen IH (1997) Membrane localization and guanine nucleotide sensitivity of medullary $\mathrm{I}_{1}$-imidazoline binding sites. Neurochem Int 30:17-23.

Escribá PV, Sastre M, Wang H, Regunathan S, Reis DJ, and García-Sevilla JA (1994) Immunodetection of putative imidazoline receptor proteins in the human and rat brain and other tissues. Neurosci Lett 178:81-84.

Fantozzi R, Luciani G, Masini E, Blandina P, and Mannaioni P (1980) Clonidine and naloxone-induced opiate withdrawal: a comparison between clonidine and morphine in man. Subst Alcohol Actions Misuse 1:369-373.

Fellmann L, Nascimento AR, Tibiriça E, and Bousquet P (2013a) Murine models for pharmacological studies of the metabolic syndrome. Pharmacol Ther 137:331-340.

Fellmann L, Regnault V, Greney H, Gasparik V, Muscat A, Max J-P, Gigou L, Oréa V, Chetrite G, Pizard A, et al. (2013b) A new pyrroline compound selective for $\mathrm{I}_{1^{-}}$ imidazoline receptors improves metabolic syndrome in rats. J Pharmacol Exp Ther 346:370-380.

Felsen D, Ernsberger P, Sutaria PM, Nejat RJ, Nguyen P, May M, Breslin DS, Marion DN, and Vaughan ED Jr (1994) Identification, localization and functional analysis of imidazoline and alpha adrenergic receptors in canine prostate. J Pharmacol Exp Ther 268:1063-1071.

Ferrari F, Fiorentino S, Mennuni L, Garofalo P, Letari O, Mandelli S, Giordani A, Lanza M, and Caselli G (2011) Analgesic efficacy of CR4056, a novel imidazoline-2 receptor ligand, in rat models of inflammatory and neuropathic pain. $J$ Pain Res 4:111-125.

Freitas AE, Neis VB, and Rodrigues ALS (2016) Agmatine, a potential novel therapeutic strategy for depression. Eur Neuropsychopharmacol 26:1885-1899.
Friedrich VL Jr, Martinelli GP, Prell GD, and Holstein GR (2007) Distribution and cellular localization of imidazoleacetic acid-ribotide, an endogenous ligand at imidazol(in)e and adrenergic receptors, in rat brain. J Chem Neuroanat 33:53-64.

Garau C, Miralles A, and García-Sevilla JA (2013) Chronic treatment with selective $\mathrm{I}_{2}$-imidazoline receptor ligands decreases the content of pro-apoptotic markers in rat brain. $J$ Psychopharmacol 27:123-134.

García-Sevilla JA, Escribá PV, Busquets X, Walzer C, and Guimón J (1996) Platelet imidazoline receptors and regulatory $\mathrm{G}$ proteins in patients with major depression. Neuroreport 8:169-172.

García-Sevilla JA, Escribá PV, and Guimón J (1999) Imidazoline receptors and human brain disorders. Ann N Y Acad Sci 881:392-409.

Gargalidis-Moudanos C and Parini A (1995) Selectivity of rilmenidine for $\mathrm{I}_{1}$-imidazoline-binding sites in rabbit proximal tubule cells. J Cardiovasc Pharmacol 26 (Suppl 2):S59-S62.

Gasparik V, Greney H, Schann S, Feldman J, Fellmann L, Ehrhardt J-D, and Bousquet $\mathrm{P}$ (2015) Synthesis and biological evaluation of 2-aryliminopyrrolidines as selective ligands for $\mathrm{I}_{1}$ imidazoline receptors: discovery of new sympatho-inhibitory hypotensive agents with potential beneficial effects in metabolic syndrome. J Med Chem 58 : 878-887.

Gatti PJ, Hill KJ, Da Silva AM, Norman WP, and Gillis RA (1988) Central nervous system site of action for the hypotensive effect of clonidine in the cat. J Pharmacol Exp Ther 245:373-380.

Gentili F, Cardinaletti C, Carrieri A, Ghelfi F, Mattioli L, Perfumi M, Vesprini C, and Pigini $M$ (2006) Involvement of $\mathrm{I}_{2}$-imidazoline binding sites in positive and negative morphine analgesia modulatory effects. Eur J Pharmacol 553:73-81.

Gilad GM and Gilad VH (2014) Long-term (5 years), high daily dosage of dietary agmatine--evidence of safety: a case report. J Med Food 17:1256-1259.

Gilad GM, Salame K, Rabey JM, and Gilad VH (1996) Agmatine treatment is neuroprotective in rodent brain injury models. Life Sci 58:41-46.

Glennon RA, Dukat M, Grella B, Hong S, Costantino L, Teitler M, Smith C, Egan C, Davis K, and Mattson MV (2000) Binding of $\beta$-carbolines and related agents at serotonin $\left(5-\mathrm{HT}\left({ }_{2}\right)\right.$ and 5-HT( $\left.\left(_{1 \mathrm{~A}}\right)\right)$, dopamine $(\mathrm{D}(2))$ and benzodiazepine receptors. Drug Alcohol Depend 60:121-132.

Glover V, Liebowitz J, Armando I, and Sandler M (1982) Beta-carbolines as selective monoamine oxidase inhibitors: in vivo implications. J Neural Transm (Vienna) 54: $209-218$.

Gold MS, Donabedian RK, and Redmond DE Jr (1978) Further evidence for alpha-2 adrenergic receptor mediated inhibition of prolactin secretion: the effect of yohimbine. Psychoneuroendocrinology 3:253-260.

Gomez RE, Ernsberger P, Feinland G, and Reis DJ (1991) Rilmenidine lowers arterial pressure via imidazole receptors in brainstem $\mathrm{C} 1$ area. Eur J Pharmacol 195: 181-191.

Gowing L, Ali R, White JM, and Mbewe D (2017) Buprenorphine for managing opioid withdrawal. Cochrane Database Syst Rev 2:CD002025.

Greenberg DA, Prichard DC, and Snyder SH (1976) Alpha-noradrenergic receptor binding in mammalian brain: differential labeling of agonist and antagonist states. Life Sci 19:69-76.

Greney H, Bricca G, Dontenwill M, Stutzmann J, Bousquet P, and Belcourt A (1994) Characterization of imidazoline binding protein(s) solubilized from human brainstem: studies with $\left[{ }^{3} \mathrm{H}\right]$ idazoxan and $\left[{ }^{3} \mathrm{H}\right]$ clonidine. Neurochem Int 25:183-191.

Greney H, Dontenwill M, Vonthron C, and Bousquet P (1997) Further biochemical characterization of imidazoline binding sites from the human brainstem. Fundam Clin Pharmacol 11:63-67.

Greney H, Ronde P, Magnier C, Maranca F, Rascente C, Quaglia W, Giannella M, Pigini M, Brasili L, Lugnier C, et al. (2000) Coupling of I(1) imidazoline receptors to the cAMP pathway: studies with a highly selective ligand, benazoline. Mol Pharmacol 57:1142-1151.

Greney H, Urosevic D, Schann S, Dupuy L, Bruban V, Ehrhardt J-D, Bousquet P, and Dontenwill M (2002) $\left[{ }^{125} \mathrm{I}\right] 2$-(2-chloro-4-iodo-phenylamino)-5-methyl-pyrroline (LNP 911), a high-affinity radioligand selective for $\mathrm{I}_{1}$ imidazoline receptors. $M o$ Pharmacol 62:181-191.

Gustafson I, Miyauchi Y, and Wieloch TW (1989) Postischemic administration of idazoxan, an alpha-2 adrenergic receptor antagonist, decreases neuronal damage in the rat brain. $J$ Cereb Blood Flow Metab 9:171-174.

Gustafson I, Westerberg E, and Wieloch T (1990) Protection against ischemiainduced neuronal damage by the alpha 2-adrenoceptor antagonist idazoxan: influence of time of administration and possible mechanisms of action. J Cereb Blood Flow Metab 10:885-894.

Guyenet PG and Cabot JB (1981) Inhibition of sympathetic preganglionic neurons by catecholamines and clonidine: mediation by an alpha-adrenergic receptor $J$ Neurosci 1:908-917.

Han Z, Cheng ZH, Liu S, Yang JL, Xiao MJ, Zheng RY, and Hou ST (2012) Neurovascular protection conferred by 2 -BFI treatment during rat cerebral ischemia Biochem Biophys Res Commun 424:544-548.

Han Z, Xiao MJ, Shao B, Zheng RY, Yang GY, and Jin K (2009) Attenuation of ischemia-induced rat brain injury by 2-(-2-benzofuranyl)-2-imidazoline, a high selectivity ligand for imidazoline I(2) receptors. Neurol Res 31:390-395.

Han Z, Yang JL, Jiang SX, Hou ST, and Zheng RY (2013) Fast, non-competitive and reversible inhibition of NMDA-activated currents by 2-BFI confers neuroprotection. PLoS One 8:e64894.

Han Z, Zhang HX, Tian JS, Zheng RY, and Hou ST (2010) 2-(-2-benzofuranyl)-2imidazoline induces Bcl-2 expression and provides neuroprotection against transient cerebral ischemia in rats. Brain Res 1361:86-92.

Heemskerk FM, Dontenwill M, Greney H, Vonthron C, and Bousquet P (1998) Evidence for the existence of imidazoline-specific binding sites in synaptosomal plasma membranes of the bovine brainstem. J Neurochem $\mathbf{7 1}$ : 2193-2202.

Herraiz T and Galisteo $\mathrm{J}$ (2003) Tetrahydro-beta-carboline alkaloids occur in fruits and fruit juices. Activity as antioxidants and radical scavengers. J Agric Food Chem 51:7156-7161. 
Herraiz T and Galisteo J (2014) Naturally-occurring tetrahydro- $\beta$-carboline alkaloids derived from tryptophan are oxidized to bioactive $\beta$-carboline alkaloids by heme peroxidases. Biochem Biophys Res Commun 451:42-47.

Herraiz T and Papavergou E (2004) Identification and occurrence of tryptamine- and tryptophan-derived tetrahydro-beta-carbolines in commercial sausages. J Agric Food Chem 52:2652-2658.

Hieble JP and Ruffolo RR Jr (1995) Possible structural and functional relationships between imidazoline receptors and alpha 2-adrenoceptors. Ann N Y Acad Sci 763:8-21.

Hoefke W, Kobinger W, and Walland A (1975) Relationship between activity and structure in derivatives of clonidine. Arzneimittelforschung 25:786-793.

Hoobler SW and Sagastume E (1971) Clonidine hydrochloride in the treatment of hypertension. Am J Cardiol 28:67-73.

Hosseini AR, Jackman GP, King PR, Louis WJ, and Gundlach AL (1998) Pharmacology and subcellular distribution of $\left[{ }^{3} \mathrm{H}\right]$ rilmenidine binding sites in rat brain. J Auton Nerv Syst 72:129-136.

Howe PR (1985) Blood pressure control by neurotransmitters in the medulla oblongata and spinal cord. J Auton Nerv Syst 12:95-115.

Hudson AL, Gough R, Tyacke R, Lione L, Lalies M, Lewis J, Husbands S, Knight P, Murray F, Hutson P, et al. (1999a) Novel selective compounds for the investigation of imidazoline receptors. Ann N Y Acad Sci 881:81-91.

Hudson AL, Luscombe S, Gouch RE, Nutt DJ, and Tyacke RJ (1999b) Endogenous indoleamines demonstrate moderate affinity for $\mathrm{I}_{2}$ binding sites. Ann N Y Acad Sci 881:212-216

Hunskaar S and Hole K (1987) The formalin test in mice: dissociation between inflammatory and non-inflammatory pain. Pain 30:103-114.

Hunt GE, Atrens DM, Becker FT, and Paxinos G (1978) Alpha-adrenergic modulation of hypothalamic self-stimulation: effects of phenoxybenzamine, yohimbine, dexamphetamine and their interactions with clonidine. Eur J Pharmacol 53:1-8.

Husbands SM, Glennon RA, Gorgerat S, Gough R, Tyacke R, Crosby J, Nutt DJ, Lewis JW, and Hudson AL (2001) $\beta$-carboline binding to imidazoline receptors. Drug Alcohol Depend 64:203-208.

Ishida-Takahashi A, Horie M, Tsuura Y, Ishida H, Ai T, and Sasayama S (1996) Block of pancreatic ATP-sensitive $\mathrm{K}+$ channels and insulinotrophic action by the antiarrhythmic agent, cibenzoline. Br J Pharmacol 117:1749-1755.

Jiang SX, Zheng RY, Zeng JQ, Li XL, Han Z, and Hou ST (2010) Reversible inhibition of intracellular calcium influx through NMDA receptors by imidazoline I(2) receptor antagonists. Eur J Pharmacol 629:12-19.

Jonas JC, Plant TD, and Henquin JC (1992) Imidazoline antagonists of alpha 2adrenoceptors increase insulin release in vitro by inhibiting ATP-sensitive $\mathrm{K}+$ channels in pancreatic beta-cells. Br J Pharmacol 107:8-14.

Jones TZ, Giurato L, Guccione S, and Ramsay RR (2007) Interactions of imidazoline ligands with the active site of purified monoamine oxidase A. FEBS $J$ 274: $1567-1575$

Jordan S, Jackson HC, Nutt DJ, and Handley SL (1996) Discriminative stimulus produced by the imidazoline $\mathrm{I}_{2}$ site ligand, 2-BFI. J Psychopharmacol 10:273-278.

Kagawa K, Hayashi Y, Itoh I, Iwasaki M, Takada K, Kamibayashi T, Yamatodani A, and Mashimo $\mathrm{T}$ (2005) Identification of the central imidazoline receptor subtype involved in modulation of halothane-epinephrine arrhythmias in rats. Anesth Analg 101:1689-1694.

Kamibayashi T, Mammoto T, Hayashi Y, Yamatodani A, Takada K, Sasaki S, and Yoshiya I (1995) Further characterization of the receptor mechanism involved in the antidysrhythmic effect of dexmedetomidine on halothane/epinephrine dysrhythmias in dogs. Anesthesiology 83:1082-1089.

Kamisaki Y, Ishikawa T, Takao Y, Omodani H, Kuno N, and Itoh T (1990) Binding of $\left[{ }^{3} \mathrm{H}\right]$ p-aminoclonidine to two sites, alpha 2-adrenoceptors and imidazoline binding sites: distribution of imidazoline binding sites in rat brain. Brain Res 514:15-21.

Kapur H, Rouot B, and Snyder SH (1979) Binding to alpha-adrenergic receptors: differential pharmacological potencies and binding affinities of benzodioxanes. Eur $J$ Pharmacol 57:317-328.

Kawamoto S, Hirakata H, Sugita N, and Fukuda K (2015) Bidirectional effects of dexmedetomidine on human platelet functions in vitro. Eur J Pharmacol $\mathbf{7 6 6}$ 122-128.

Keller B and García-Sevilla JA (2015) Immunodetection and subcellular distribution of imidazoline receptor proteins with three antibodies in mouse and human brains: effects of treatments with I1- and I-imidazoline drugs. J Psychopharmacol 29:996-1012.

Keynan O, Mirovsky Y, Dekel S, Gilad VH, and Gilad GM (2010) Safety and efficacy of dietary agmatine sulfate in lumbar disc-associated radiculopathy. An open-label, dose-escalating study followed by a randomized, double-blind, placebo-controlled trial. Pain Med 11:356-368.

Khan A, Camel G, and Perry HM Jr (1970) Clonidine (Catapres): a new antihypertensive agent. Curr Ther Res Clin Exp 12:10-18.

Kimura A, Tyacke RJ, Robinson JJ, Husbands SM, Minchin MC, Nutt DJ, and Hudson AL (2009) Identification of an imidazoline binding protein: creatine kinase and an imidazoline-2 binding site. Brain Res 1279:21-28.

King PR, Gundlach AL, Jarrott B, and Louis WJ (1992) Nature of $\left[{ }^{3} \mathrm{H}\right]$ rilmenidine binding to membranes of rat cerebral cortex. Am J Hypertens 5:64S-68S.

King PR, Gundlach AL, and Louis WJ (1995a) Quantitative autoradiographic localization in rat brain of alpha 2-adrenergic and non-adrenergic I-receptor binding sites labelled by $\left[{ }^{3} \mathrm{H}\right]$ rilmenidine. Brain Res 675:264-278.

King PR, Suzuki S, Hosseini AR, Iakovidis D, Nero TL, Jackman GP, Louis WJ, and Gundlach $\mathrm{AL}$ (1998) [ $\left.{ }^{3} \mathrm{H}\right]$ Rilmenidine-labelled imidazoline-receptor binding sites co-localize with $\left[{ }^{3} \mathrm{H}\right] 2$-(benzofuranyl)-2-imidazoline-labelled imidazolinereceptor binding sites and monoamine oxidase-B in rabbit, but not rat, kidney. J Auton Nerv Syst 72:118-128.

King PR, Suzuki S, Louis WJ, and Gundlach AL (1995b) Differential characteristics and localisation of $\left[{ }^{3} \mathrm{H}\right]$ oxazoline and $\left[{ }^{3} \mathrm{H}\right]$ imidazoline binding sites in rat kidney. Eur J Pharmacol 281:341-346.

King PR, Suzuki S, Louis WJ, and Gundlach AL (1995c) Distribution of nonadrenergic $\left[{ }^{3} \mathrm{H}\right]$ rilmenidine binding in rat brain and kidney. Ann N Y Acad Sci $\mathbf{7 6 3}$ 194-207.
King PR, Suzuki S, Nero TL, Gundlach AL, and Louis WJ (1993) Molecular studies of alpha-2-adrenoceptor and catecholamine-insensitive imidazoline-receptor binding sites using $\left[{ }^{3} \mathrm{H}\right]$-rilmenidine in rat brain and kidney. $J$ Hypertens Suppl 11: S160-S161.

Klupp H, Knappen F, Otsuka Y, Streller I, and Teichmann H (1970) Effects of clonidine on central sympathetic tone. Eur J Pharmacol 10:225-229.

Kobinger W (1967) [On the mechanism of action of a new antihypertensive substance with imidazoline structure]. Naunyn Schmiedebergs Arch Exp Pathol Pharmakol 258:48-58.

Kobinger W and Walland A (1967) Investigations into the mechanism of the hypotensive effect of 2-(2,6-dichlorphenylamino)-2-imidazoline-HCl. Eur J Pharmacol 2 $155-162$.

Kobinger W and Walland A (1972a) Evidence for a central activation of a vagal cardiodepressor reflex by clonidine. Eur J Pharmacol 19:203-209.

Kobinger W and Walland A (1972b) Facilitation of vagal reflex bradycardia by an action of clonidine on central $\alpha$-receptors. Eur J Pharmacol 19:210-217.

Koletsky RJ, Velliquette RA, and Ernsberger P (2003) The role of I(1)-imidazoline receptors and alpha(2)-adrenergic receptors in the modulation of glucose and lipid metabolism in the SHROB model of metabolic syndrome X. Ann N Y Acad Sci 1009:251-261.

Kou YR, Ernsberger P, Cragg PA, Cherniack NS, and Prabhakar NR (1991) Role of alpha 2-adrenergic receptors in the carotid body response to isocapnic hypoxia. Respir Physiol 83:353-364

Kubo T and Misu Y (1981) Pharmacological characterisation of the alphaadrenoceptors responsible for a decrease of blood pressure in the nucleus tractus solitarii of the rat. Naunyn Schmiedebergs Arch Pharmacol 317:120-125.

Laduron PM (1988) Stereospecificity in binding studies. A useful criterion though insufficient to prove the presence of receptors. Biochem Pharmacol 37:37-40.

Lalies MD, Hibell A, Hudson AL, and Nutt DJ (1999) Inhibition of central monoamine oxidase by imidazoline2 site-selective ligands. Ann N Y Acad Sci 881 $114-117$.

Langer SZ, Adler-Graschinsky E, and Giorgi O (1977) Physiological significance of alpha-adrenoceptor-mediated negative feedback mechanism regulating noradrenaline release during nerve stimulation. Nature 265:648-650.

Langin D, Paris H, and Lafontan M (1990) Binding of $\left[{ }^{3} \mathrm{H}\right]$ idazoxan and of its methoxy derivative $\left[{ }^{3} \mathrm{H}\right]$ RX821002 in human fat cells: $\left[{ }^{3} \mathrm{H}\right]$ idazoxan but not $\left[{ }^{3} \mathrm{H}\right]$ RX821002 labels additional non-alpha 2-adrenergic binding sites. Mol Pharmacol 37:876-885.

Lanza M, Ferrari F, Menghetti I, Tremolada D, and Caselli G (2014) Modulation of imidazoline $\mathrm{I}_{2}$ binding sites by $\mathrm{CR} 4056$ relieves postoperative hyperalgesia in male and female rats. Br J Pharmacol 171:3693-3701.

Laubie M, Schmitt H, and Drouillat M (1976) Action of clonidine on the baroreceptor pathway and medullary sites mediating vagal bradycardia. Eur J Pharmacol 38: 293-303.

Laviță SI, Aro R, Kiss B, Manto M, and Duez P (2016) The role of $\beta$-carboline alkaloids in the pathogenesis of essential tremor. Cerebellum 15:276-284.

Leclerc G, Rouot B, Schwartz J, Velly J, and Wermuth CG (1980) Studies on some para-substituted clonidine derivatives that exhibit an alpha-adrenoceptor stimulant activity. $\mathrm{Br} J$ Pharmacol 71:5-9.

Leprán I and Papp JG (1994) Effect of moxonidine on arrhythmias induced by coronary artery occlusion and reperfusion. $J$ Cardiovasc Pharmacol 24 (Suppl 1): S9-S15.

Li F, Zhang ZX, Liu YF, Xu HQ, Hou ST, and Zheng RY (2012) 2-BFI ameliorates EAE-induced mouse spinal cord damage: effective therapeutic time window and possible mechanisms. Brain Res 1483:13-19.

Li G, Regunathan S, Barrow CJ, Eshraghi J, Cooper R, and Reis DJ (1994) Agmatine: an endogenous clonidine-displacing substance in the brain. Science 263:966-969.

Li JX, Thorn DA, Qiu Y, Peng BW, and Zhang Y (2014) Antihyperalgesic effects of imidazoline $\mathrm{I}(2)$ receptor ligands in rat models of inflammatory and neuropathic pain. Br J Pharmacol 171:1580-1590.

Li JX and Zhang Y (2011) Imidazoline $\mathrm{I}_{2}$ receptors: target for new analgesics? Eur $J$ Pharmacol 658:49-56.

Li JX, Zhang Y, and Winter JC (2011) Morphine-induced antinociception in the rat: supra-additive interactions with imidazoline $\mathrm{I}_{2}$ receptor ligands. Eur J Pharmacol 669:59-65

Li Y, Cheng K-C, Asakawa A, Amitani H, Takimoto Y, Runtuwene J, and Inui A (2015) Activation of imidazoline- $\mathrm{I}_{3}$ receptors ameliorates pancreatic damage. Clin Exp Pharmacol Physiol 42:964-971.

Lipski J, Przybylski J, and Solnicka E (1976) Reduced hypotensive effect of clonidine after lesions of the nucleus tractus solitarii in rats. Eur J Pharmacol 38:19-22.

MacDonald JF and Nowak LM (1990) Mechanisms of blockade of excitatory amino acid receptor channels. Trends Pharmacol Sci 11:167-172.

MacInnes N and Handley SL (2002) Characterization of the discriminable stimulus produced by 2-BFI: effects of imidazoline I(2)-site ligands, MAOIs, beta-carbolines, agmatine and ibogaine. $\mathrm{Br}$ J Pharmacol 135:1227-1234.

MacInnes N and Handley SL (2003) Potential serotonergic and noradrenergic involvement in the discriminative stimulus effects of the selective imidazoline $\mathrm{I}_{2}$-site ligand 2-BFI. Pharmacol Biochem Behav 75:427-433.

MacKinnon AC, Brown CM, Spedding M, and Kilpatrick AT (1989) $\left[{ }^{3} \mathrm{H}\right]$-idazoxan binds with high affinity to two sites on hamster adipocytes: an alpha 2 adrenoceptor and a non-adrenoceptor site. Br J Pharmacol 98:1143-1150.

MacKinnon AC, Stewart M, Olverman HJ, Spedding M, and Brown CM (1993) $\left[{ }^{3} \mathrm{H}\right] \mathrm{p}-$ aminoclonidine and $\left[{ }^{3} \mathrm{H}\right]$ idazoxan label different populations of imidazoline sites on rat kidney. Eur J Pharmacol 232:79-87.

Mahmoudi J, Majdi A, Lattanzi S, Di Napoli M, Bershad EM, Rodrigues CMP, and Divani AA (2018) Imidazoline receptor agonists for managing hypertension may hold promise for treatment of intracerebral hemorrhage. Curr Mol Med 18 $241-251$. 
Mammoto T, Kamibayashi T, Hayashi Y, Takada K, Yamatodani A, and Yoshiya I (1995) Rilmenidine prevents epinephrine-induced arrhythmias in halothaneanesthetized dogs. J Cardiovasc Pharmacol 26 (Suppl 2):S40-S43.

Mammoto T, Kamibayashi T, Hayashi Y, Yamatodani A, Takada K, and Yoshiya I (1996) Antiarrhythmic action of rilmenidine on adrenaline-induced arrhythmia via central imidazoline receptors in halothane-anaesthetized dogs. $\mathrm{Br} J$ Pharmacol 117:1744-1748.

Maziveyi M and Alahari SK (2015) Breast cancer tumor suppressors: a special emphasis on novel protein nischarin. Cancer Res 75:4252-4259.

McLean LS, Crane L, Baziard-Mouysset G, and Edwards LP (2014) Antiproliferative effect induced by novel imidazoline S43126 in PC12 cells is mediated by ROS, stress activated MAPKs and caspases. Pharmacol Rep 66:937-945.

McRaven DR, Kroetz FW, Kioschos JM, and Kirkendall WM (1971) The effect of clonidine on hemodynamics in hypertensive patients. Am Heart J 81:482-489.

Meeley MP, Ernsberger PR, Granata AR, and Reis DJ (1986) An endogenous clonidine-displacing substance from bovine brain: receptor binding and hypotensive actions in the ventrolateral medulla. Life Sci 38:1119-1126.

Meeley MP, Hensley ML, Ernsberger P, Felsen D, and Reis DJ (1992) Evidence for a bioactive clonidine-displacing substance in peripheral tissues and serum. Biochem Pharmacol 44:733-740.

Meeley MP, Towle AC, Ernsberger P, and Reis DJ (1988) A specific antiserum recognizes clonidine-displacing substance: implications for the structure of the brain's own clonidine. Neurosci Lett 84:84-90.

Meregalli C, Ceresa C, Canta A, Carozzi VA, Chiorazzi A, Sala B, Oggioni N, Lanza M, Letari O, Ferrari F, et al. (2012) CR4056, a new analgesic $\mathrm{I}_{2}$ ligand, is highly effective against bortezomib-induced painful neuropathy in rats. J Pain Res 5: $151-167$.

Mest HJ, Thomsen P, and Raap A (1995) Antiarrhythmic effect of the selective I1imidazoline receptor modulator moxonidine on ouabain-induced cardiac arrhythmia in guinea pigs. Ann N Y Acad Sci 763:620-633.

Miach PJ, Dausse J, and Meyer P (1978) Direct biochemical demonstration of two types of alpha-adrenoreceptor in rat brain. Nature 274:492-494

Michel MC and Ernsberger P (1992) Keeping an eye on the I site: imidazolinepreferring receptors. Trends Pharmacol Sci 13:369-370.

Michel MC and Insel PA (1989) Are there multiple imidazoline binding sites? Trends Pharmacol Sci 10:342-344.

Min JW, Peng BW, He X, Zhang Y, and Li JX (2013) Gender difference in epileptogenic effects of 2-BFI and BU224 in mice. Eur $J$ Pharmacol 718:81-86.

Miralles A, Olmos G, Sastre M, Barturen F, Martin I, and García-Sevilla JA (1993) Discrimination and pharmacological characterization of $\mathrm{I}_{2}$-imidazoline sites with $\left[{ }^{3} \mathrm{H}\right]$ idazoxan and alpha-2 adrenoceptors with $\left[{ }^{3} \mathrm{H}\right] \mathrm{RX} 821002$ (2-methoxy idazoxan in the human and rat brains. J Pharmacol Exp Ther 264:1187-1197.

Molderings GJ, Donecker K, and Göthert M (1995) Characterization of nonadrenergic $\left[{ }^{3} \mathrm{H}\right]$ clonidine binding sites in rat stomach: high affinity of imidazolines, guanidines and sigma ligands. Naunyn Schmiedebergs Arch Pharmacol $\mathbf{3 5 1}$ 561-564.

Molderings GJ, Göthert M, and von Kügelgen I (2007) Characterization of an antiproliferative effect of imidazoline receptor ligands on PC12 cells. Pharmacol Rep 59:789-794.

Molderings GJ, Schmidt K, Bönisch H, and Göthert M (1996) Inhibition of 5-HT3 receptor function by imidazolines in mouse neuroblastoma cells: potential involvement of sigma 2 binding sites. Naunyn Schmiedebergs Arch Pharmacol 354: $245-252$.

Mongraw-Chaffin M, Foster MC, Anderson CAM, Burke GL, Haq N, Kalyani RR, Ouyang P, Sibley CT, Tracy R, Woodward M, et al. (2018) Metabolically healthy obesity, transition to metabolic syndrome, and cardiovascular risk. J Am Coll Cardiol 71:1857-1865.

Monks LK, Cosgrove KE, Dunne MJ, Ramsden CA, Morgan NG, and Chan SL (1999) Affinity isolation of imidazoline binding proteins from rat brain using 5 -aminoefaroxan as a ligand. FEBS Lett 447:61-64.

Moretti M, Matheus FC, de Oliveira PA, Neis VB, Ben J, Walz R, Rodrigues AL, and Prediger RD (2014) Role of agmatine in neurodegenerative diseases and epilepsy. Front Biosci (Elite Ed) 6:341-359.

Morgan NG and Chan SL (2001) Imidazoline binding sites in the endocrine pancreas can they fulfil their potential as targets for the development of new insulin secretagogues? Curr Pharm Des 7:1413-1431.

Morgan NG, Chan SL, Mourtada M, Monks LK, and Ramsden CA (1999) Imidazolines and pancreatic hormone secretion. Ann N Y Acad Sci 881:217-228.

Morgan NG, Cooper EJ, Squires PE, Hills CE, Parker CA, and Hudson AL (2003) Comparative effects of efaroxan and $\beta$-carbolines on the secretory activity of rodent and human $\beta$ cells. Ann N Y Acad Sci 1009:167-174.

Mukaddam-Daher S (2012) An "I" on cardiac hypertrophic remodelling: imidazoline receptors and heart disease. Can J Cardiol 28:590-598.

Musgrave IF and Badoer E (2000) Harmane produces hypotension following microinjection into the RVLM: possible role of I(1)-imidazoline receptors. $\mathrm{Br}$ $J$ Pharmacol 129:1057-1059.

Musgrave IF, Krautwurst D, Hescheler J, and Schultz G (1995) Clonidine and cirazoline inhibit activation of nicotinic channels in PC-12 cells. Ann N Y Acad Sci 763:272-282

Nascimento AR, Machado MV, Gomes F, Vieira AB, Gonçalves-de-Albuquerque CF, Lessa MA, Bousquet P, and Tibiriçá E (2016) Central sympathetic modulation reverses microvascular alterations in a rat model of high-fat diet-induced metabolic syndrome. Microcirculation 23:320-329.

Nayler WG, Rosenbaum M, McInnes I, and Lowe TE (1966) Effect of a new hypotensive drug, ST155, on the systemic circulation. Am Heart J 72:764-770.

Nielsen AN, Mathiesen C, and Blackburn-Munro G (2004) Pharmacological characterisation of acid-induced muscle allodynia in rats. Eur $J$ Pharmacol 487:93-103.

Niu C-S, Wu H-T, Cheng K-C, Lin K-C, Chen C-T, and Cheng J-T (2011) A novel mechanism for decreasing plasma lipid level from imidazoline I-1 receptor activation in high fat diet-fed mice. Horm Metab Res 43:458-463.
Olmos G, Alemany R, Boronat MA, and García-Sevilla JA (1999a) Pharmacologic and molecular discrimination of $\mathrm{I}_{2}$-imidazoline receptor subtypes. Ann N Y Acad Sci 881:144-160.

Olmos G, DeGregorio-Rocasolano N, Paz Regalado M, Gasull T, Assumpció Boronat M, Trullas R, Villarroel A, Lerma J, and García-Sevilla JA (1999b) Protection by imidazol(ine) drugs and agmatine of glutamate-induced neurotoxicity in cultured cerebellar granule cells through blockade of NMDA receptor. $\mathrm{Br} J$ Pharmacol 127: 1317-1326.

Olmos G, Kulkarni RN, Haque M, and MacDermot J (1994) Imidazolines stimulate release of insulin from RIN-5AH cells independently from imidazoline I1 and $\mathrm{I}_{2}$ receptors. Eur J Pharmacol 262:41-48.

Olmos G, Ribera J, and García-Sevilla JA (1996) Imidazoli(di)ne compounds interact with the phencyclidine site of NMDA receptors in the rat brain. Eur J Pharmacol 310:273-276.

Ozaita A, Olmos G, Boronat MA, Lizcano JM, Unzeta M, and García-Sevilla JA (1997) Inhibition of monoamine oxidase A and B activities by imidazol(ine)/guanidine drugs, nature of the interaction and distinction from $\mathrm{I}_{2}$-imidazoline receptors in rat liver. Br J Pharmacol 121:901-912.

Parini A, Moudanos CG, Pizzinat N, and Lanier SM (1996) The elusive family of imidazoline binding sites. Trends Pharmacol Sci 17:13-16.

Parker CA, Anderson NJ, Robinson ESJ, Price R, Tyacke RJ, Husbands SM, Dillon MP, Eglen RM, Hudson AL, Nutt DJ, et al. (2004) Harmane and harmalan are bioactive components of classical clonidine-displacing substance. Biochemistry 43 16385-16392.

Parker CA, Hudson AL, Nutt DJ, Dillon MP, Eglen RM, Chan SL, Morgan NG, and Crosby J (1999a) Extraction of active clonidine-displacing substance from bovine lung and comparison with clonidine-displacing substance extracted from other tissues. Eur J Pharmacol 378:213-221.

Parker CA, Hudson AL, Nutt DJ, Dillon MP, Eglen RM, and Crosby J (1999b) Comparison of crude methanolic CDS extracts from various tissues. Ann N Y Acad Sci 881:92-96.

Parker CA, Hudson AL, Nutt DJ, Dillon MP, Eglen RM, and Crosby J (1999c) Tryptophan: a distinct but biologically inactive component of clonidine-displacing substance. Br J Pharmacol 127:U41.

Parker CA, Hudson AL, Nutt DJ, Dillon MP, Eglen RM, and Crosby J (2000) Isolation of RP-HPLC pure clonidine-displacing substance from NG108-15 cells. Eur $J$ Pharmacol 387:27-30.

Parker CA, Nabulsi N, Holden D, Lin SF, Cass T, Labaree D, Kealey S, Gee AD, Husbands SM, and Quelch D (2014) Evaluation of 11C-BU99008, a PET ligand for the imidazoline2 binding sites in rhesus brain. J Nucl Med 55:838-844.

Pfau W and Skog K (2004) Exposure to beta-carbolines norharman and harman. $J$ Chromatogr B Analyt Technol Biomed Life Sci 802:115-126.

Piletz JE, Andorn AC, Unnerstall JR, and Halaris A (1991) Binding of $\left[{ }^{3} \mathrm{H}\right]-\mathrm{p}$-aminoclonidine to alpha 2-adrenoceptor states plus a non-adrenergic site on human platelet plasma membranes. Biochem Pharmacol 42:569-584.

Piletz JE, Aricioglu F, Cheng JT, Fairbanks CA, Gilad VH, Haenisch B, Halaris A, Hong S, Lee JE, Li J, et al. (2013) Agmatine: clinical applications after 100 years in translation. Drug Discov Today 18:880-893.

Piletz JE, Ivanov TR, Sharp JD, Ernsberger P, Chang CH, Pickard RT, Gold G, Roth $\mathrm{B}$, Zhu H, Jones JC, et al. (2000) Imidazoline receptor antisera-selected (IRAS) cDNA: cloning and characterization. DNA Cell Biol 19:319-329.

Piletz JE, Jones JC, Zhu H, Bishara O, and Ernsberger P (1999) Imidazoline receptor antisera-selected cDNA clone and mRNA distribution. Ann N Y Acad Sci 881:1-7.

Piletz JE and Sletten K (1993) Nonadrenergic imidazoline binding sites on human platelets. J Pharmacol Exp Ther 267:1493-1502.

Pocock S, Wilhelmsen L, Dickstein K, Francis G, and Wittes J (2004) The data monitoring experience in the MOXCON trial. Eur Heart $J$ 25:1974-1978.

Poisson D, Christen MO, and Sannajust F (2000) Protective effects of I(1)-antihypertensive agent moxonidine against neurogenic cardiac arrhythmias in halothane-anesthetized rabbits. J Pharmacol Exp Ther 293:929-938.

Prell GD, Martinelli GP, Holstein GR, Matulić-Adamić J, Watanabe KA, Chan SL, Morgan NG, Haxhiu MA, and Ernsberger P (2004) Imidazoleacetic acid-ribotide: an endogenous ligand that stimulates imidazol(in)e receptors. Proc Natl Acad Sci USA 101:13677-13682.

Proks P and Ashcroft FM (1997) Phentolamine block of KATP channels is mediated by Kir6.2. Proc Natl Acad Sci USA 94:11716-11720.

Qiu Y, He XH, Zhang Y, and Li JX (2014a) Discriminative stimulus effects of the novel imidazoline $\mathrm{I}_{2}$ receptor ligand CR4056 in rats. Sci Rep 4:6605.

Qiu Y, Thorn DA, Zhang Y, He X, and Li JX (2014b) Behavioral effects of the imidazoline $\left.\mathrm{I}_{2}\right)$ receptor ligand BU99006 in rats. Behav Pharmacol 25:130-136.

Qiu Y, Zhang Y, and Li JX (2015) Discriminative stimulus effects of the imidazoline $\mathrm{I}_{2}$ receptor ligands BU224 and phenyzoline in rats. Eur $J$ Pharmacol 749:133-141. Rawls SM, Tallarida RJ, and Zisk J (2006) Agmatine and a cannabinoid agonist, WIN 55212-2, interact to produce a hypothermic synergy. Eur J Pharmacol 553:89-98 Regunathan S, Evinger MJ, Meeley MP, and Reis DJ (1991a) Effects of clonidine and other imidazole-receptor binding agents on second messenger systems and calcium influx in bovine adrenal chromaffin cells. Biochem Pharmacol 42:2011-2018.

Regunathan S, Meeley MP, and Reis DJ (1991b) Clonidine-displacing substance from bovine brain binds to imidazoline receptors and releases catecholamines in adrenal chromaffin cells. Mol Pharmacol 40:884-888.

Regunathan S and Piletz JE (2003) Regulation of inducible nitric oxide synthase and agmatine synthesis in macrophages and astrocytes. Ann N Y Acad Sci 1009:20-29.

Regunathan S and Reis DJ (1996) Imidazoline receptors and their endogenous ligands. Annu Rev Pharmacol Toxicol 36:511-544.

Reid JL (2001) Update on rilmenidine: clinical benefits. Am J Hypertens 14: $322 \mathrm{~S}-324 \mathrm{~S}$.

Reis DJ, Doba N, Snyder DW, and Nathan MA (1977) Brain lesions and hypertension: chronic lability and elevation of arterial pressure produced by electrolytic lesions and 6-hydroxydopamine treatment of nucleus tractus solitarii (NTS) in rat and cat. Prog Brain Res 47:169-188. 
Reis DJ and Regunathan S (2000) Is agmatine a novel neurotransmitter in brain? Trends Pharmacol Sci 21:187-193.

Remaury A, Raddatz R, Ordener C, Savic S, Shih JC, Chen K, Seif I, De Maeyer E Lanier SM, and Parini A (2000) Analysis of the pharmacological and molecular heterogeneity of I(2)-imidazoline-binding proteins using monoamine oxidasedeficient mouse models. Mol Pharmacol 58:1085-1090.

Rockhold RW and Caldwell RW (1979) Effect of lesions of the nucleus tractus solitarii on the cardiovascular actions of clonidine in conscious rats. Neuropharmacology 18: 347-354.

Rockhold RW and Caldwell RW (1980) Cardiovascular effects following clonidine microinjection into the nucleus tractus solitarii of the rat. Neuropharmacology 19: 919-922.

Roegel JC, Yannoulis N, De Jong W, Feldman J, and Bousquet P (1998) Preventive effect of rilmenidine on the occurrence of neurogenic ventricular arrhythmias in rabbits. J Hypertens Suppl 16:S39-S43.

Roegel JC, Yannoulis N, De Jong W, Monassier L, Feldman J, and Bousquet P (1996) Inhibition of centrally induced ventricular arrhythmias by rilmenidine and idazoxan in rabbits. Naunyn Schmiedebergs Arch Pharmacol 354:598-605.

Rommelspacher H, Brüning G, Susilo R, Nick M, and Hill R (1985) Pharmacology of harmalan (1-methyl-3,4-dihydro-beta-carboline). Eur J Pharmacol 109:363-371.

Rösen P, Ohly P, and Gleichmann H (1997) Experimental benefit of moxonidine on glucose metabolism and insulin secretion in the fructose-fed rat. J Hypertens Suppl 15:S31-S38.

Rouot B, Leclerc G, and Wermuth CG (1976) Clonidine and related analogues. Quantitative correlations. $J$ Med Chem 19:1049-1054.

Rouot B, Quennedey MC, and Schwartz J (1982) Characteristics of the $\left[{ }^{3} \mathrm{H}\right]$ yohimbine binding on rat brain alpha2-adrenoceptors. Naunyn Schmiedebergs Arch Pharmacol 321:253-259.

Rouot BR and Snyder SH (1979) $\left[{ }^{3} \mathrm{H}\right]$ Para-amino-clonidine: a novel ligand which binds with high affinity to alpha-adrenergic receptors. Life Sci 25:769-774.

Rovati LC, Brambilla N, Blicharski T, Probert NJ, Vitalini C, Giacovelli G, Girolami $\mathrm{F}$, and D'Amato M (2017) A randomized, placebo-controlled, double-blind, phase II clinical trial of the first-in-class imidazoline-2 receptor ligand CR4056 in pain from knee osteoarthritis and disease phenotypes (Abstract). Arthritis Rheumatol 69 (Suppl 10):1193.

Ruffolo RR Jr, Dillard RD, Waddell JE, and Yaden EL (1979a) Receptor interactions of imidazolines. III. Structure-activity relationships governing alpha adrenergic receptor occupation and receptor activation for mono- and dimethoxy-substituted tolazoline derivatives in rat aorta. J Pharmacol Exp Ther 211:733-738.

Ruffolo RR Jr, Dillard RD, Yaden EL, and Waddell JE (1979b) Receptor interactions of imidazolines. II. Affinities and efficacies of hydroxy-substituted tolazoline derivatives in rat aorta. J Pharmacol Exp Ther 211:74-79.

Ruffolo RR Jr, Rosing EL, and Waddell JE (1979c) Receptor interactions of imidazolines. I. Affinity and efficacy for alpha adrenergic receptors in rat aorta. J Pharmacol Exp Ther 209:429-436.

Ruffolo RR Jr, Waddell JE, and Yaden EL (1980a) Receptor interactions of imidazolines. IV. Structural requirements for alpha adrenergic receptor occupation and receptor activation by clonidine and a series of structural analogs in rat aorta J Pharmacol Exp Ther 213:267-272.

Ruffolo RR Jr, Yaden EL, and Waddell JE (1980b) Receptor interactions of imidazolines. V. Clonidine differentiates postsynaptic alpha adrenergic receptor subtypes in tissues from the rat. $J$ Pharmacol Exp Ther 213:557-561.

Sampson C, Zhang Y, Del Bello F, and Li JX (2012) Effects of imidazoline $\mathrm{I}_{2}$ receptor ligands on acute nociception in rats. Neuroreport 23:73-77.

Sánchez-Blázquez P, Boronat MA, Olmos G, García-Sevilla JA, and Garzón J (2000) Activation of $\mathrm{I}(2)$-imidazoline receptors enhances supraspinal morphine analgesia in mice: a model to detect agonist and antagonist activities at these receptors. $\mathrm{Br}$ $J$ Pharmacol 130:146-152.

Schann S, Bruban V, Pompermayer K, Feldman J, Pfeiffer B, Renard P, Scalbert E, Bousquet P, and Ehrhardt JD (2001) Synthesis and biological evaluation of pyrrolinic isosteres of rilmenidine. Discovery of cis-/trans-dicyclopropylmethyl-(4,5dimethyl-4,5-dihydro-3H-pyrrol-2-yl)-amine (LNP 509), an $\mathrm{I}_{1}$ imidazoline receptor selective ligand with hypotensive activity. J Med Chem 44:1588-1593.

Schann S, Greney H, Gasparik V, Dontenwill M, Rascente C, Lacroix G, Monassier L, Bruban V, Feldman J, Ehrhardt J-D, et al. (2012) Methylation of imidazoline related compounds leads to loss of $\alpha_{2}$-adrenoceptor affinity. Synthesis and biological evaluation of selective $\mathrm{I}_{1}$ imidazoline receptor ligands. Bioorg Med Chem 20: $4710-4715$

Schmitt H and Fénard S (1973a) Action of $\alpha$-adrenergic blocking drugs on the sympathetic centres and their interactions with the central sympatho-inhibitory effect of clonidine. Arzneimittelforschung 23:40-45.

Schmitt H and Fénard S (1973b) Decrease in the sympatho-inhibitory action of clonidine after destruction of the sympatho-inhibitory area. Experientia 29:1247-1249

Schmitt H and Fénard S (1972) New evidence for an $\alpha$-adrenergic component in the sympathetic centres: centrally mediated decrease in sympathetic tone by L-dopa and its antagonism by piperoxane and yohimbine. Eur J Pharmacol 17:293-296.

Schuster CR and Johanson CE (1988) Relationship between the discriminative stimulus properties and subjective effects of drugs. Psychopharmacol Ser 4: 161-175.

Scriabine A, Stavorski J, Wenger HC, Torchiana ML, and Stone CA (1970) Cardiac slowing effects of clonidine (ST-155) in dogs. J Pharmacol Exp Ther 171:256-264.

Separovic D, Kester M, and Ernsberger P (1996) Coupling of $\mathrm{I}_{1}$-imidazoline receptors to diacylglyceride accumulation in PC12 rat pheochromocytoma cells. Mol Pharmacol 49:668-675.

Separovic D, Kester M, Haxhiu MA, and Ernsberger P (1997) Activation of phosphatidylcholine-selective phospholipase $\mathrm{C}_{\text {by }} \mathrm{I}_{1}$-imidazoline receptors in PC12 cells and rostral ventrolateral medulla. Brain Res 749:335-339.

Shaw J, Hunyor SN, and Korner PI (1971) The peripheral circulatory effects of clonidine and their role in the production of arterial hypotension. Eur J Pharmacol 14:101-111.
Siemian JN, Li J, Zhang Y, and Li JX (2016a) Interactions between imidazoline $\mathrm{I}_{2}$ receptor ligands and acetaminophen in adult male rats: antinociception and schedule-controlled responding. Psychopharmacology (Berl) 233:873-882.

Siemian JN, Obeng S, Zhang Y, Zhang Y, and Li JX (2016b) Antinociceptive interactions between the imidazoline I2 receptor agonist 2-BFI and opioids in rats: role of efficacy at the $\mu$-opioid receptor. J Pharmacol Exp Ther 357: $509-519$

Siemian JN, Qiu Y, Zhang Y, and Li JX (2017) Role of intracellular $\mathrm{Ca}^{2+}$ signaling in the antinociceptive and discriminative stimulus effects of the imidazoline $\mathrm{I}_{2}$ receptor agonist 2-BFI in rats. Psychopharmacology (Berl) 234:3299-3307.

Siemian JN, Wang K, Zhang Y, and Li JX (2018) Mechanisms of imidazoline $\mathrm{I}_{2}$ receptor agonist-induced antinociception in rats: involvement of monoaminergic neurotransmission. Br J Pharmacol 175:1519-1534.

Stabile AM, Aceros H, Stockmeyer K, Abdel Rahman AA, Noiseux N, and Mukaddam-Daher S (2011) Functional and molecular effects of imidazoline receptor activation in heart failure. Life Sci 88:493-503.

Stähle H (2000) A historical perspective: development of clonidine. Best Pract Res Clin Anaesthesiol 14:237-246.

Stähle H, Daniel H, Kobinger W, Lillie C, and Pichler L (1980) Chemistry, pharmacology, and structure-activity relationships with a new type of imidazolines exerting a specific bradycardic action at a cardiac site. J Med Chem 23:1217-1222.

Starke K and Endo T (1976) Presynaptic alpha-adrenoceptors. Gen Pharmacol 7: 307-312.

Starke K, Taube HD, and Browski E (1977) Presynaptic receptor systems in catecholaminergic transmission. Biochem Pharmacol 26:259-268.

Stone LS, Kitto KF, Eisenach JC, Fairbanks CA, and Wilcox GL (2007) ST91 [2-(2,6diethylphenylamino)-2-imidazoline hydrochloride]-mediated spinal antinociception and synergy with opioids persists in the absence of functional alpha-2A- or alpha2C-adrenergic receptors. J Pharmacol Exp Ther 323:899-906.

Sun Z, Chang CH, and Ernsberger P (2007) Identification of IRAS/nischarin as an I1imidazoline receptor in PC12 rat pheochromocytoma cells. J Neurochem 101: 99-108.

Susilo R and Rommelspacher H (1987) Formation of a beta-carboline (1,2,3,4-tetrahydro-1-methyl-beta-carboline-1-carboxylic acid) following intracerebroventricular injection of tryptamine and pyruvic acid. Naunyn Schmiedebergs Arch Pharmacol 335:70-76.

Swedberg K, Bergh CH, Dickstein K, McNay J, and Steinberg M; Moxonidine Investigators (2000) The effects of moxonidine, a novel imidazoline, on plasma norepinephrine in patients with congestive heart failure. $J$ Am Coll Cardiol 35: 398-404.

Takada K, Hayashi Y, Kamibayashi T, Mammoto T, Yamatodani A, Kitamura S, and Yoshiya I (1997) The involvement of pertussis toxin-sensitive G proteins in the post receptor mechanism of central $\mathrm{I}_{1}$-imidazoline receptors. $\mathrm{Br} J$ Pharmacol 120 : $1575-1581$

Tanabe M, Kino Y, Honda M, and Ono H (2006) Presynaptic $\mathrm{I}_{1}$-imidazoline receptors reduce GABAergic synaptic transmission in striatal medium spiny neurons. $J$ Neurosci 26:1795-1802.

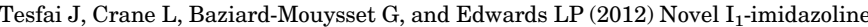
agonist S43126 augment insulin secretion in Min6 cells. J Diabetes Metab 3:183.

Tesson F, Limon-Boulez I, Urban P, Puype M, Vandekerckhove J, Coupry I, Pompon $\mathrm{D}$, and Parini A (1995) Localization of $\mathrm{I}_{2}$-imidazoline binding sites on monoamine oxidases. J Biol Chem 270:9856-9861.

Tesson F, Prip-Buus C, Lemoine A, Pegorier JP, and Parini A (1991) Subcellular distribution of imidazoline-guanidinium-receptive sites in human and rabbit liver. Major localization to the mitochondrial outer membrane. J Biol Chem 266: $155-160$.

Thorn DA, An XF, Zhang Y, Pigini M, and Li JX (2012) Characterization of the hypothermic effects of imidazoline $\mathrm{I}_{2}$ receptor agonists in rats. $\mathrm{Br}$ J Pharmacol 166: 1936-1945

Thorn DA, Qiu Y, Jia S, Zhang Y, and Li JX (2016a) Antinociceptive effects of imidazoline ${ }_{\text {I2 }}$ receptor agonists in the formalin test in rats. Behav Pharmacol 27. 377-383.

Thorn DA, Siemian JN, Zhang Y, and Li JX (2015) Anti-hyperalgesic effects of imidazoline $\mathrm{I}_{2}$ receptor ligands in a rat model of inflammatory pain: interactions with oxycodone. Psychopharmacology (Berl) 232:3309-3318.

Thorn DA, Zhang Y, and Li JX (2016b) Effects of the imidazoline $\mathrm{I}_{2}$ receptor agonist 2 -BFI on the development of tolerance to and behavioural/physical dependence on morphine in rats. Br J Pharmacol 173:1363-1372.

Thorn DA, Zhang Y, and Li JX (2017) Tolerance and cross-tolerance to the antinociceptive effects of oxycodone and the imidazoline $\mathrm{I}_{2}$ receptor agonist phenyzoline in adult male rats. Psychopharmacology (Berl) 234:1871-1880.

Thorn DA, Zhang Y, Peng BW, Winter JC, and Li JX (2011) Effects of imidazoline $\mathrm{I}_{2}$ receptor ligands on morphine- and tramadol-induced antinociception in rats. Eur $J$ Pharmacol 670:435-440.

Tibiriça E, Feldman J, and Bousquet P (1992) Contribution of catecholaminergic neurons of the dorsomedial and ventrolateral medulla oblongata to the hypotensive effect of clonidine in spontaneously hypertensive rats: in vivo voltammetric studies. J Hypertens 10:1327-1334.

Tibiriç E, Feldman J, Mermet C, Monassier L, Gonon F, and Bousquet P (1991) Selectivity of rilmenidine for the nucleus reticularis lateralis, a ventrolatera medullary structure containing imidazoline-preferring receptors. Eur J Pharmacol 209:213-221.

Tibiriça E, Mermet C, Feldman J, Gonon F, and Bousquet P (1989) Correlation between the inhibitory effect on catecholaminergic ventrolateral medullary neurons and the hypotension evoked by clonidine: a voltammetric approach. J Pharmacol Exp Ther 250:642-647.

Trolin G (1975) Effects of pentobarbitone and decerebration on the clonidine-induced circulatory changes. Eur J Pharmacol 34:1-7.

Tyacke RJ, Myers JFM, Venkataraman A, Mick I, Turton S, Passchier J, Husbands SM, Rabiner EA, Gunn RN, Murphy PS, et al. (2018) Evaluation of ${ }^{11}$ C-BU99008, 
a PET ligand for the imidazoline2 binding site in human brain. J Nucl Med 59: $1597-1602$.

U'Prichard DC, Greenberg DA, and Snyder SH (1977) Binding characteristics of a radiolabeled agonist and antagonist at central nervous system alpha noradrenergic receptors. Mol Pharmacol 13:454-473.

Urosevic D, Schann S, Ehrhardt JD, Bousquet P, and Greney H (2004) LNP 906, the first high-affinity photoaffinity ligand selective for $\mathrm{I}_{1}$ imidazoline receptors [published correction appears in Br J Pharmacol (2004) 142:1368]. Br J Pharmacol 142: 609-617.

van Zwieten PA (1973) The central action of antihypertensive drugs, mediated via central alpha-receptors. J Pharm Pharmacol 25:89-95.

Vauquelin G, De Backer JP, Ladure P, and Flamez A (1999) Identification of I1 and $\mathrm{I}_{2}$ imidazoline receptors in striatum membranes from different species. Ann N Y Acad Sci 881:135-143.

Velliquette RA and Ernsberger P (2003) The role of I(1)-imidazoline and alpha(2)adrenergic receptors in the modulation of glucose metabolism in the spontaneously hypertensive obese rat model of metabolic syndrome X. J Pharmacol Exp Ther 306: 646-657.

Velliquette RA, Kossover R, Previs SF, and Ernsberger P (2006) Lipid-lowering actions of imidazoline antihypertensive agents in metabolic syndrome X. Naunyn Schmiedebergs Arch Pharmacol 372:300-312.

Vlahakos D, Gavras I, and Gavras H (1985) Alpha-adrenoceptor agonists applied in the area of the nucleus tractus solitarii in the rat: effect of anesthesia on cardiovascular responses. Brain Res 347:372-375.

Wang H, McGowan D, Regunathan S, Bramwell S, Li G, and Reis DJ (1993) Idazoxan-specific antiserum recognizes an endogenous clonidine-displacing substance (CDS) in human serum and CSF. Soc Neurosci Abstr 19:1691.

Wang H, Regunathan S, Meeley MP, and Reis DJ (1992) Isolation and characterization of imidazoline receptor protein from bovine adrenal chromaffin cells. Mol Pharmacol 42:792-801.

Wang L-G, Zeng J, Yuan W-J, Su D-F, and Wang W-Z (2007) Comparative study of NMDA and AMPA/kainate receptors involved in cardiovascular inhibition produced by imidazoline-like drugs in anaesthetized rats. Exp Physiol 92:849-858.

Weiss M, Bouchoucha S, Aiad F, Ayme-Dietrich E, Dali-Youcef N, Bousquet P, Greney H, and Niederhoffer N (2015) Imidazoline-like drugs improve insulin sensitivity through peripheral stimulation of adiponectin and AMPK pathways in a rat model of glucose intolerance. Am J Physiol Endocrinol Metab 309:E95-E104.
Wikberg JE, Uhlén S, and Chhajlani V (1991) Medetomidine stereoisomers delineate two closely related subtypes of idazoxan (imidazoline) I-receptors in the guinea pig. Eur J Pharmacol 193:335-340.

Wu N, Su RB, and Li J (2008) Agmatine and imidazoline receptors: their role in opioid analgesia, tolerance and dependence. Cell Mol Neurobiol 28:629-641.

Yamanaka H, Hayashi Y, Iwasaki M, Kamibayashi T, Yamatodani A, and Mashimo T (2010) Activation of phosphatidylinositol 3-kinase/Akt signaling pathway and endogenous nitric oxide are needed for the antiarrhythmic effect of centrally administered rilmenidine. Eur $J$ Pharmacol 647:155-160.

Yang P-S, Wu H-T, Chung H-H, Chen C-T, Chi C-W, Yeh C-H, and Cheng J-T (2012) Rilmenidine improves hepatic steatosis through p38-dependent pathway to higher the expression of farnesoid X receptor. Naunyn Schmiedebergs Arch Pharmaco 385:51-56

Yang XC and Reis DJ (1999) Agmatine selectively blocks the N-methyl-D-aspartate subclass of glutamate receptor channels in rat hippocampal neurons. J Pharmacol Exp Ther 288:544-549.

Zandberg P, De Jong W, and De Wied D (1979) Effect of catecholamine-receptor stimulating agents on blood pressure after local application in the nucleus tractus solitarii of the medulla oblongata. Eur J Pharmacol 55:43-56.

Zhang J and Abdel-Rahman AA (2005) Mitogen-activated protein kinase phosphorylation in the rostral ventrolateral medulla plays a key role in imidazoline (i1) receptor-mediated hypotension. J Pharmacol Exp Ther 314:945-952.

Zhang J and Abdel-Rahman AA (2008) Inhibition of nischarin expression attenuates rilmenidine-evoked hypotension and phosphorylated extracellular signal-regulated kinase $1 / 2$ production in the rostral ventrolateral medulla of rats. J Pharmacol Exp Ther 324:72-78.

Zhang J, El-Mas MM, and Abdel-Rahman AA (2001) Imidazoline I(1) receptorinduced activation of phosphatidylcholine-specific phospholipase $\mathrm{C}$ elicits mitogenactivated protein kinase phosphorylation in PC12 cells. Eur J Pharmacol 415: 117-125.

Zhang W, Li X, Liu Y, Chen H, and Gong J (2017) Activation of imidazoline $\mathrm{I}_{1}$ receptor by moxonidine regulates the progression of liver fibrosis in the Nrf2dependent pathway. Biomed Pharmacother 90:821-834.

Zhu YB, Xia NG, Zhang YT, Wang XS, Liang SS, Yin WY, Xu HQ, Hou ST, and Zheng $\mathrm{RY}$ (2015) Brain protection conferred by long-term administration of 2-(2-benzofuranyl)-2-imidazoline against experimental autoimmune encephalomyelitis. Neurochem Res 40:572-578. 